medRxiv preprint doi: https://doi.org/10.1101/2021.07.19.21260635; this version posted July 19, 2021. The copyright holder for this preprint (which was not certified by peer review) is the author/funder, who has granted medRxiv a license to display the preprint in perpetuity.

It is made available under a CC-BY 4.0 International license .

\title{
Public opinion on sharing data from UK health services for clinical and research purposes without explicit consent
}

- Linda A. Jones ${ }^{1}$, patient and public involvement lead. ORCID 0000-0001-9347-5715.

- Jenny R. Nelder ${ }^{1}$, project manager.

- Joseph M. Fryer ${ }^{1}$, data architect.

- Philip H. Alsop ${ }^{2}$, research advisory group member.

- Michael R. Geary ${ }^{2}$, research advisory group member.

- Mark Prince ${ }^{2}$, research advisory group member.

- Rudolf N. Cardinal 1,3,* (rnc1001@cam.ac.uk), university lecturer in clinical informatics and honorary consultant liaison psychiatrist. ORCID 0000-0002-8751-5167.

${ }^{1}$ Department of Psychiatry, University of Cambridge, UK. ${ }^{2}$ Unaffiliated. ${ }^{3}$ Cambridgeshire and Peterborough NHS Foundation Trust, UK. ${ }^{*}$ Corresponding author.

Version of: 19 July 2021. Abstract word count: 300. Text word count: 4475.

\section{1. $\quad$ Abstract}

BACKGROUND. In the UK, National Health Service (NHS/HSC) data is variably shared between healthcare organizations for direct care, and increasingly used in de-identified forms for research. Few large-scale studies have examined public opinion on sharing, including the treatment of mental health $(\mathrm{MH})$ versus physical health $(\mathrm{PH})$ data.

METHODS. Pre-registered anonymous online survey open to all UK residents, recruiting Feb-Sep 2020. Participants were randomized to one of three framing statements regarding $\mathrm{MH}$ versus $\mathrm{PH}$ data.

FINDINGS. Participants numbered 29275; 40\% had experienced a MH condition. A majority supported identifiable data sharing for direct clinical care without explicit consent, but $20 \%$ opposed this. Preference for clinical/identifiable sharing decreased with distance and was slightly less for $\mathrm{MH}$ than $\mathrm{PH}$ data, with a small framing effect. Preference for research/de-identified data sharing without explicit consent showed the same small $\mathrm{PH} / \mathrm{MH}$ and framing effects, plus greater preference for sharing structured data than de-identified free text. There was net support for research sharing to the NHS, academic institutions, and national research charities, net ambivalence about sharing to profit-making companies researching treatments, and net opposition to sharing to other companies (similar to sharing publicly). Deidentified linkage to non-health data was generally supported, except to data held by private companies. We report demographic influences on preference. A clear majority supported a single NHS mechanism to choose uses of their data. Support for data sharing increased during the pandemic.

INTERPRETATION. Support for healthcare data sharing for direct care without explicit consent is broad but not universal. There is net support for the sharing of de-identified data for research to the NHS, academia, and the charitable sector, but not the commercial sector. A single national NHS-hosted system for patients to control the use of their NHS data for clinical purposes and for research would have broad public support.

FUNDING. MRC. 
medRxiv preprint doi: https://doi.org/10.1101/2021.07.19.21260635; this version posted July 19, 2021. The copyright holder for this preprint (which was not certified by peer review) is the author/funder, who has granted medRxiv a license to display the preprint in perpetuity.

It is made available under a CC-BY 4.0 International license .

\section{Introduction}

In the United Kingdom (UK), health-related information is recorded routinely by health care professionals and patients within the National Health Service (NHS; England, Scotland, Wales) or Health and Social Care (HSC; Northern Ireland), henceforth "NHS" for brevity. When combined with personal identifiers such as names and addresses, the data represent "confidential patient information" (CPI), ${ }^{1}$ used to provide care and managed according to standard principles. ${ }^{2-7}$ It is "owned" legally and managed by the NHS organisation recording it. ${ }^{5,8}$ De-identified or anonymised forms of the data may be used for research (Fig.1) without explicit consent, ${ }^{5,6}$ as pledged by the NHS. ${ }^{9}$ Identifiable data may be used for research with consent, orunder restricted circumstances-without. ${ }^{1,5,6}$ "Fully" anonymised data are not subject to UK data protection legislation. ${ }^{5,6}$ However, even supposedly anonymised data relating to individual people carries some risk of re-identification via "jigsaw" attacks. ${ }^{10}$

Our understanding of public wishes about data sharing is incomplete. ${ }^{11}$ Information is sometimes not shared clinically when it should be, ${ }^{3,12}$ and patients may be surprised and frustrated by failures to share in a "national" health service. ${ }^{13,14}$ Previous work, whilst establishing themes in public views on data linkage and sharing for research, ${ }^{11,15-21}$ has highlighted the very small scale of many studies, and the paucity of research about the views of minority groups and the acceptability of sharing some types of data, such as mental health (MH) data. Mental illnesses can carry significant stigma ${ }^{22}$ but are associated with substantial loss of life expectancy, ${ }^{23}$ necessitating improvements in research and care. Some research requires multi-source data, but linkage is complex and may involve transient use of identifiable information. ${ }^{24}$ It is unclear to what extent the public supports such work, and whether support varies with the type of data to which health data is linked (e.g. education versus criminal justice); there is little prior research in this area. ${ }^{18}$ Proposed national systems for NHS data research such as "care.data" have previously aroused public ire, ${ }^{25}$ as have information governance (IG) breaches ${ }^{26}$ and there is current debate about the newest NHS data sharing proposal, General Practice Data for Planning and Research (GPDPR). ${ }^{8,27}$

What do patients and the public want now? We studied views on the sharing of identifiable health data (for clinical purposes) and de-identified health data (for research) within the UK. We examined data destinations ranging from local NHS services to public distribution. We distinguished $\mathrm{MH}$ and physical health $(\mathrm{PH})$ data, and for research also structured versus free-text (narrative) data. We asked about data linkage for research. We superimposed a randomized experiment to quantify how opinions on sharing were affected by the "framing" 28 of risk versus benefit. We examined the effect of the COVID-19 pandemic upon preferences. We sought views on potential systems to govern NHS data sharing for clinical and research purposes and to offer direct participation in research.

\section{Methods}

\subsection{Patient and public involvement}

The research team advertised and formed a research advisory group (RAG) comprising patients and carers, who designed the study with the research team. Patients, carers, and other members of the public participated in the study.

\subsection{Approvals}

We obtained NHS ethics approvals (East of Scotland Research Ethics Service, reference 19/ES/0144) and pre-registered the study (https://doi.org/10.1186/ISRCTN37444142). 
medRxiv preprint doi: https://doi.org/10.1101/2021.07.19.21260635; this version posted July 19, 2021. The copyright holder for this preprint (which was not certified by peer review) is the author/funder, who has granted medRxiv a license to display the preprint in perpetuity.

It is made available under a CC-BY 4.0 International license .

\subsection{Inclusion and exclusion criteria; sample size}

The inclusion criteria were current residence in the UK and informed consent. The ability to take an online survey (alone or supported) was implicit. Participants under 16 required the permission of their parent or guardian to participate and were asked to report whether they had assistance. We sought a power of 0.9 to detect a "small" effect (Cohen's $d=0 \cdot 1$ ) for the framing intervention (described below), with an estimated minimum $n=433$ /group, but beyond that sought a large representative sample of the UK population.

\subsection{Recruitment}

Approvals covered public announcements and recruitment via health service sites, in person or through a variety of media. The study was adopted onto the National Institute for Health Research (NIHR) Clinical Research Network (CRN) portfolio; 216 general practice (GP) surgeries and 154 large healthcare organizations (e.g. acute care Trusts, MH Trusts, community hospitals, ambulance Trusts) supported recruitment. The study ran from 2020-02-07 to 2020-09-30.

\subsection{Survey}

Data were collected using REDCap. ${ }^{29}$ The survey is reproduced in the Supplementary Methods. It asked for the respondent's views on current and desirable practice for sharing identifiable data for clinical care purposes; personal experience of $\mathrm{MH} / \mathrm{PH}$ conditions and care; preference for sharing identifiable $\mathrm{PH} / \mathrm{MH}$ data (for clinical care purposes) to a range of NHS "destinations"; preference for sharing de-identified structured $\mathrm{PH} / \mathrm{MH}$ data (for research) to a range of potential research "destinations"; similarly for data including de-identified free-text notes; views about potential systems for managing data consent in the NHS; views about linkage for research to non-NHS data sources; and demographics.

\subsection{Randomized framing intervention}

We hypothesized that the context of questioning would affect willingness to share MH versus $\mathrm{PH}$ data, and sought to control and measure this effect. Before we asked about willingness to share different kinds of health data, we presented one of three framing statements: neutral, "concern" (about MH data being more sensitive), or "holistic" (about the importance of joined-up PH/MH care) (Supplementary Methods). Participants were randomized to one of the three statements.

\subsection{Data processing}

Where participants agreed to leave a postcode, this was converted to a larger Office for National Statistics (ONS) geographical area, to prevent inadvertent identification. The geographical area was linked to its known population and Index of Multiple Deprivation (IMD). If the participant provided sufficient information, the ONS National Statistics Socio-Economic Classification (NS-SEC) was also calculated. (See Supplementary Methods.)

After removal of all free text, anonymised data are available from [URL_to_be_established_within_https://www.data.cam.ac.uk/repository], with participants' consent. ${ }^{30}$

\subsection{Pandemic}

By chance, our study spanned the UK onset of the COVID-19 pandemic. This had many consequences, including "lockdowns". Major changes were made to NHS data handling, including instructions to share CPI for public health purposes relating to the pandemic, ${ }^{31}$ media reports of sharing of patient-level de-identified data with industry, ${ }^{32}$ and guidance for GPs to include additional information in patients' Summary Care 
medRxiv preprint doi: https://doi.org/10.1101/2021.07.19.21260635; this version posted July 19, 2021. The copyright holder for this preprint (which was not certified by peer review) is the author/funder, who has granted medRxiv a license to display the preprint in perpetuity.

It is made available under a CC-BY 4.0 International license .

Record (SCR, England) unless they had previously opted out. ${ }^{33}$ We examined whether the pandemic was associated with changes in preference relating to data sharing, using 2020-03-23 (first UK "lockdown") as the split point (factor "pandemic": levels "before lockdown", "at/after lockdown").

\subsection{Analysis}

We analysed using $\mathrm{R} v 3.6 .3 .{ }^{34}$ We analysed categorical associations via $\chi^{2}$ tests, and effects upon ordinal Likert-type scales (phrased linguistically to approximate interval scales) via analysis of variance (ANOVA). With a large sample size, the central limit theorem means that the distribution of means and mean differences tends to normal even though the parent population is non-normal, and ANOVA is robust to non-normality, ${ }^{35-}$ ${ }^{37}$ permitting ANOVA of discrete dependent variables. Scales measuring likelihood were quantified as -2 very unlikely, -1 unlikely, 0 not sure, +1 likely, +2 very likely. Yes/no scales were quantified as -1 no, 0 not sure, +1 yes. Models involving within-subjects terms were analysed using the lmer and lmerTest packages, using type III sums of squares, and are expressed thus ( "is predicted by"; $\mathrm{A} \times \mathrm{B}$ interaction; $\mathrm{A} * \mathrm{~B}$ denotes the inclusion of main effects $\mathrm{A}$ and $\mathrm{B}$ and their interactions). Statistics are shown to 3 significant figures and degrees of freedom are rounded to integers. We set $\alpha=0 \cdot 05$, and report "NS" for "not significant" and "VLP" for a very low $p$ value, $p<2 \cdot 2 \times 10^{-16}$.

Opinions on sharing clinical/identifiable data were analysed using a model termed $\mathrm{C} 1$ : sharing $\sim$ destination*nature*framing*pandemic $+(1 \mid$ subject $)$. "Destination" had four levels (local, regional, national, UK-wide), "nature" had two (PH, MH), and framing had three (neutral, MH concern, holistic). We followed up nature $\times$ framing interactions by analysing $\mathrm{MH}$ and $\mathrm{PH}$ data separately using the simplified model C1B: sharing destination $*$ framing $+(1 \mid$ subject $)$.

To examine the effects of demographic factors and experience, we used a larger model, C2: sharing $\sim$ destination $*$ nature $*$ framing $*$ pandemic + age + gender + ethnicity + education + sexuality + religion + nat ion+imd_quartile+nssec + mh_experience*nature+(1|subject). This was only possible for people who provided all necessary demographic information. Levels for demographic factors were as per Supplementary Table 1, plus sexuality (two levels: heterosexual/straight, LGBT+ [including homosexual/gay/lesbian, bisexual, other/self-described]) and NS-SEC (five levels).

Opinions on sharing de-identified data for research were analysed using model R1: sharing destination*nature*detail*framing*pandemic+(1|subject). "Destination" had six levels (NHS, academia, charities, companies conducting treatment research, other companies, publicly); "detail" had two levels (structured only, free text); other factors were as before. To examine nature $\times$ framing interactions, we used the simplified model R1B: sharing destination*framing $+(1 \mid$ subject $)$. For demographic analysis we used model R2: sharing $\sim$ destination $*$ nature $*$ detail $*$ framing*pandemic + age + gender + ethnicity + education + sexuality + religi on+nation+imd_quartile+nssec $+m h$ experience*nature+(1|subject $)$.

Sensitivity analyses were conducted by weighting to UK population demographic proportions. Effect size plots were created for key models. (See Supplementary Methods.)

Willingness for linkage to non-NHS data for research (data source, eight levels) was analysed for all participants using model L1: willingness $\sim$ source*pandemic $+(1 \mid$ subject $)$. For demographic analysis we used model willingness $\sim$ source ${ }^{*}$ pandemic + age + gender+ethnicity + education + sexuality + religion + nation + imd_quartile + nssec + mh_experience $+(1 \mid$ subject $)$.

A thematic analysis was performed on free-text comments (see Supplementary Methods). 
medRxiv preprint doi: https://doi.org/10.1101/2021.07.19.21260635; this version posted July 19, 2021. The copyright holder for this preprint (which was not certified by peer review) is the author/funder, who has granted medRxiv a license to display the preprint in perpetuity.

It is made available under a CC-BY 4.0 International license .

\section{Results}

\subsection{Participants}

Consenting participants numbered 29275. Recruitment is shown in Supplementary Figure 1A-B; 8019 participated before UK "lockdown" and 21256 on/after that date. Not everyone completed the survey: participation by stage is shown in Suppl.Fig.1C. Median completion time was 18.4 minutes. Participants were evenly distributed across framing conditions (neutral 9812, MH concern 9744, holistic $9719 ; \chi_{2}^{2}=0.475$, NS).

Demographics are shown in Suppl.Fig.2 (with free-text responses in Supplementary Results). Relative to the UK population (Supplementary Table 1), our sample under-represented the youngest and oldest age ranges, males, those of non-white ethnicity, those with less formal education, those professing a religion, residents of UK nations other than England, and people living in more deprived areas. Weighting yielded substantial though incomplete improvement. There was coverage of most UK local authority areas (Suppl.Fig.2I).

Forty percent of participants had experienced a MH condition (Suppl.Fig.3), primarily depression and anxiety disorders. Of them, $85 \%$ had used MH services, primarily their GP and NHS psychological therapy services. Eighty-eight percent of respondents had used PH services, primarily GP and outpatient services.

\section{2. $\quad$ Sharing identifiable data for clinical purposes}

Understanding of current NHS practice regarding identifiable data sharing between care providers, without asking the patient each time, are shown in Fig.2A. In practice, sharing varies by area, e.g. depending on whether a local/regional shared care record is operative in part of England, ${ }^{14}$ or according to limited national systems such as the Intra-NHS Scotland Information Sharing Accord ${ }^{38}$ and Scottish Emergency Care Summary, ${ }^{39}$ the Northern Ireland Electronic Care Record ${ }^{40}$ the English SCR,${ }^{41}$ and a variety of systems in Wales. ${ }^{42}$ To our knowledge, there is no UK-wide sharing, but $30 \%$ of respondents thought that there was free sharing of identifiable data across the UK.

When asked preferences via a single multiple-choice question (Fig.2B), there was majority (55\%) support for sharing identifiable data for direct care across the UK, without being asked first, and $76 \%$ support for sharing at least locally, but a substantial minority (20\%) said that sharing should not occur without the patient being asked first.

\subsection{Sharing mental and physical health data for clinical purposes and for research}

Willingness to share health data without being asked every time is shown in Fig.3 by purpose, type, and destination.

For clinical purposes (with identifiable data), there was strong net willingness to share (Fig.3). The most important determinant was destination, with stronger support the more local the sharing. People were slightly more willing to share $\mathrm{PH}$ than $\mathrm{MH}$ data. There were significant but very small effects of the framing statement, primarily that "MH concern" framing reduced willingness to share MH data. In the whole-sample analysis (model $\mathrm{C} 1$ ), there were highly significant effects of destination and nature, as well as interactions including nature $\times$ framing (Fig.3, Suppl.Fig.6A). This interaction was driven primarily by a simple effect of "MH concern" framing to reduce sharing for $\mathrm{MH}$ data [model $\mathrm{C} 1 \mathrm{~B}$ : $\mathrm{PH}$ data, no effect of framing $\left(F_{2,24461}=1 \cdot 18, \mathrm{NS}\right)$; $\mathrm{MH}$ data, effect of framing $\left(F_{2,24157}=8 \cdot 36, p=0 \cdot 000234\right)$; pairwise comparison within $\mathrm{MH}$ data, $\mathrm{MH}$ concern versus neutral, $p=0 \cdot 00443]$. Framing effects were also lessened for geographically broader destinations. 
medRxiv preprint doi: https://doi.org/10.1101/2021.07.19.21260635; this version posted July 19, 2021. The copyright holder for this preprint (which was not certified by peer review) is the author/funder, who has granted medRxiv a license to display the preprint in perpetuity.

It is made available under a CC-BY 4.0 International license .

For research purposes (with de-identified data), destination was an extremely strong driver of preference (Fig.3). On average, people expressed strong support for sharing to the NHS, academia, or national charities for research purposes. Support and opposition were approximately equally balanced for sharing to profitmaking companies researching treatments. There was strong net opposition to sharing to other types of companies, approximately equal to that for sharing publicly. There was a small but significant preference for sharing $\mathrm{PH}$ (versus $\mathrm{MH}$ ) data, and likewise higher preference for sharing structured-only versus free-text data. In the whole-sample analysis (model R1), there were highly significant effects of destination, nature, and detail, plus interactions including destination $\times$ nature $\times$ detail (Suppl.Fig.6B). Framing effects included nature $\times$ framing, though simple framing effects were not significant for $\mathrm{PH}$ or $\mathrm{MH}$ data separately (model R1B).

Sensitivity analyses weighted to UK population demographics (Supplementary Results) were consistent with the primary analysis.

\subsection{Linkage to non-health data for research}

We asked about linking of NHS data to non-health data sources for research. There was net support for all "state" sources and university-held data (Fig.4), but net opposition regarding private company data (Fig.4). Weighted responses were very similar (Suppl.Fig.5).

\subsection{Changes related to the COVID-19 pandemic}

Following "lockdown", willingness to share identifiable data for clinical purposes increased, with no significant change in the already high preference for local sharing, but progressive increases for sharing to more remote parts of the NHS (model C1, destination $\times$ pandemic, $F_{3,169348}=26 \cdot 6$, VLP; Fig.5A).

Willingness to share de-identified data for research purposes generally increased for more-preferred destinations (NHS, academia, charities), except in the "MH concern" framing condition (model R1, destination $\times$ pandemic, $F_{5,535334}=78 \cdot 2$, VLP; Fig.5B), but did not change for less-preferred destinations (commercial and public sharing).

Preference for linkage to university data increased (source×pandemic; Fig.5C; Suppl.Fig.6C). There was a less consistent decrease in preference for linkage to private data (Fig.6C, Suppl.Fig.6C) and police data (model L2; Fig.6C).

\subsection{Effect sizes and influence of demographic factors}

Preference varied according to demographic factors and experience of MH illness. For clinical purposes, there were several demographic effects (model C2, Fig.6A). Age was a significant factor, with the age bands most willing to share being $25-44$ and $75+$, and the 18-24 band being least willing. Males were more willing to share data than females. Those of minority ethnicity were less willing to share than those of white ethnicity. Across educational levels, those of Level 3 were most willing and those of Level 4+ least willing. Those of minority religions were less willing to share. Those from the most-deprived IMD quartile were also less willing. There were no significant effects of sexuality $\left(F_{1,12334}=2 \cdot 21\right.$, NS), NS-SEC $\left(F_{4,12335}=1 \cdot 32\right.$, NS), or nation $\left(F_{3,12335}=2 \cdot 13\right.$, NS). Personal experience of $\mathrm{MH}$ illness specifically reduced willingness to share $\mathrm{MH}$ data for clinical purposes (nature $\times \mathrm{MH}$ experience).

For research purposes, significant effects were similarly observed for age, gender, ethnicity, religion, and IMD quartile (model R2, Fig.6B). The age distribution was clearly U-shaped, with greater willingness to share among the youngest and oldest groups. As before, there was no effect of sexuality $\left(F_{1,12336}=1 \cdot 58\right.$, NS). There was no effect of education $\left(F_{4,12348}=2 \cdot 15, p=0 \cdot 072\right)$, but there was an effect of nation (with people living in Wales more willing to share and those in Scotland less so, relative to England), and of 
medRxiv preprint doi: https://doi.org/10.1101/2021.07.19.21260635; this version posted July 19, 2021. The copyright holder for this preprint (which was not certified by peer review) is the author/funder, who has granted medRxiv a license to display the preprint in perpetuity.

It is made available under a CC-BY 4.0 International license .

socioeconomic status (NS-SEC; Fig.6B). People with MH experience were significantly more likely to share $\mathrm{MH}$ data for research purposes (nature $\times \mathrm{MH}$ experience, $F_{1,296111}=6 \cdot 15, p=0 \cdot 0132$ ).

For linkage, the patterns were broadly as before (Fig.6C, Suppl.Fig.6C). Data source strongly influenced preference (education $>$ universities $\approx$ police $\approx$ housing $\approx$ transport $>$ social security $>$ immigration $\gg$ private companies). There were also effects as before of age, ethnicity, education, and IMD quartile. There was no effect of gender $\left(F_{1,12338}=2 \cdot 32, \mathrm{NS}\right)$, religion $\left(F_{2,12338}=1 \cdot 86\right.$, NS), nation $(F<1)$, or MH experience $(F<1)$, but there was now an effect of sexuality, with LGBT+ people being less willing for linkage.

\subsection{A possible national consent system}

We proposed varieties of a national system for patients to decide how their NHS data is used. Participants were most willing to sign up and change their preferences via a web site or in person (Fig.7A,C). Willingness was similar regardless of whether consent information was managed by the NHS centrally, a local NHS Trust, or the patient's GP (Fig.7B). Overall, 89\% of people said they were "likely" or "very likely" to sign up to such a system (Fig.7D). Weighted responses were very similar (Suppl.Fig.7).

Most people wanted a single NHS system to sign up for participatory research (Fig.7E; Suppl.Fig.7E).

There was broad support for the draft consent form and for adding information about contact methods, data security, and management of the consent information (Fig.7F; Suppl.Fig.7F). Forty percent (unweighted) had been unaware of the NHS National Data Opt-Out.

Comment themes ( $n>100$, Supplementary Results) included: the need for clarity around de-identification; the critical importance of healthcare data security; the desirability of data sharing; that opt-outs should be more prominent (or default) or linked to the NHS National Data Opt-Out; that profit-making use should not happen or that the NHS/patients should benefit from such profits; that clinical users should be specified in more detail; research users likewise; and that healthcare data should not be available to private or third-party companies without specific permission.

\section{Discussion}

\subsection{Summary}

Many respondents believed that health data is shared UK-wide for clinical purposes without explicit consent, when sharing is usually more limited. A majority supported such sharing, though a significant minority opposed it. Geographically broad sharing was endorsed, though with stronger support for more local destinations. People preferred to share PH (versus MH) data but this was less important than the destination.

For research, with de-identified data, there was strong net support for sharing without explicit consent to the NHS, academic research institutions, and research charities. There was net ambivalence regarding private companies researching treatments, and strong net opposition for sharing to other companies or publicly. There was a small preference for sharing PH over MH data (a smaller difference than for clinical purposes), and greater support for structured-only data over de-identified free text. There was net support for research linkage to state and university data sources, but opposition regarding data held by private companies.

Framing statements influenced $\mathrm{MH} / \mathrm{PH}$ preferences, but only to a small degree. Age, gender, ethnicity, education, religion, and IMD were associated with willingness to have health data shared or linked, though not nearly as strongly as destination/source. Personal experience of $\mathrm{MH}$ conditions was associated with reduced willingness to share $\mathrm{MH}$ data for clinical purposes, but greater willingness to share it for research. After COVID-19 lockdown there was greater willingness regarding already-preferred destinations. 
medRxiv preprint doi: https://doi.org/10.1101/2021.07.19.21260635; this version posted July 19, 2021. The copyright holder for this preprint (which was not certified by peer review) is the author/funder, who has granted medRxiv a license to display the preprint in perpetuity.

It is made available under a CC-BY 4.0 International license .

Respondents endorsed a suggested UK-wide system allowing patients to control the clinical/research uses of their data and to sign up for participatory research. They frequently emphasized the importance of data security and that NHS data should not be made available to private or third-party companies without specific permission.

\section{2. $\quad$ Strengths and weaknesses}

Strengths include patient/public involvement in the study design; the largest such study to date by $1-3$ orders of magnitude, ${ }^{15,17,19-21,43}$ giving high power; sensitivity analyses weighted to population demographics; detailed questions about data sharing for clinical/research purposes, including about the type of data and the destination, plus linkage to non-health data; a randomized framing experiment to control and measure this source of variation; quantitative analysis including of relative effect sizes; consultation on ways to improve the current situation; and serendipitous examination of the effects of COVID-19 on data sharing views.

The major weakness is that the sample remained under-representative of some groups despite weighting, with potential for unmeasured selection (including self-selection) bias, reducing generalisability.

\subsection{Destination and purpose}

The Caldicott framework (2013) and review (2016), regarding safe information sharing for direct clinical care, included the principle that the "duty to share information can be as important as the duty to protect patient confidentiality" and noted that information was often not shared when it should be, for fear of inappropriate disclosure. ${ }^{12}$ That was despite legislation creating a duty upon providers to share information with professionals when that is likely to facilitate the individual's health or social care, disclosure is in their best interests, and they do not or are not likely to object. ${ }^{44}$ That is in essence an opt-out system. This legislation conflicted with some prior studies of public opinion. ${ }^{45}$ The review noted low public understanding around how health information is used, but "an expectation that information is shared for direct care". ${ }^{12}$ We observed net support for such sharing that varied with geographical destination and was by no means universal, but was nevertheless strong.

In relation to research and other non-clinical activities, the recommendation that people be able to opt out from personal confidential data being used beyond their own direct care ${ }^{12}$ led to the NHS National Data OptOut. ${ }^{46,47}$ This relates to the use of CPI (identifiable information) for purposes such as research, conducted under NHS Act Section 251 (s251) approvals. ${ }^{1,48}$ It does not apply to direct clinical care, local audit or service evaluation, or de-identified information. ${ }^{46,47}$ Our study and others show it remains unknown to many. ${ }^{43}$ Furthermore, it is not simple and we suspect many do not fully understand its scope. Conversely, from the researcher's perspective, s251 approval is often still required for linkage studies in which researchers never see identifiable information: there is no standardized "trusted third party" system for centralized linkage of identifiable information, and inconsistent adoption of de-identified linkage methods.

"Destination" was by far the strongest driver of preference for sharing and linkage. This pattern is established: willingness to allow researchers/clinicians access to health data, but far greater reservations about industry. ${ }^{49,50}$ An important basis for this is mistrust of the security and/or motives of commercial organizations,,$^{25,26,51}$ as our participants noted.

\subsection{Demographic effects}

A common demographic theme was that minority groups (of ethnicity, religion, and sexuality) and deprived groups were less willing to share. This might reflect experience of disadvantage to, or discrimination against, these groups. ${ }^{52,53}$ Ethnicity has had mixed effects on preference for national electronic health record (EHR) systems. ${ }^{19}$ In our study, age effects were generally biphasic, with higher willingness amount the youngest and eldest. Youth may be associated with familiarity with data and/or greater support for EHRs, ${ }^{54}$ and older age 
with an increasing burden of illness, itself associated with support for national EHR systems. ${ }^{54}$ Educational effects were relatively inconsistent. Males were slightly more willing to share than females. Similar results have been observed before, ${ }^{43}$ but not always, ${ }^{54,55}$ one reason might be gender-based healthcare discrimination. ${ }^{56}$ Higher support for research sharing in Wales may relate to established national research systems there, ${ }^{57,58}$ the reasons for reduced willingness in Scotland are unclear, but similar systems there are younger. ${ }^{59}$ Those with personal experience of MH illness were less willing to share identifiable MH data for direct care. This may reflect experience of discrimination or stigma ${ }^{60,61}$ — which can have disproportionate effects in subgroups. ${ }^{61,62}$ However, the same people were more willing to share de-identified $\mathrm{MH}$ data for research, potentially reflecting increased prioritization of $\mathrm{MH}$ research. ${ }^{63}$

Demographic variations in preference may reflect differences in perception of current data rules or security practices, reasons for concern about uses of health data, or degree of concern. UK law prohibits variation of policy according to these factors. ${ }^{64}$ Better understanding and public information may be required to address these groups' concerns, ${ }^{11,65}$ but improvements in health equity are also required. ${ }^{17,52}$ However, the effect sizes of these demographic predictors were not large enough to override the net support for data sharing, given the right destinations.

\subsection{Framing and pandemic effects}

We observed small but significant framing effects. ${ }^{28}$ Our framing statements were true and non-alarmist, so real-world framing effects might sometimes be larger. Others have observed larger effects via "loss framing" (emphasizing the potential adverse consequences of not consenting over the potential benefits of consenting), and through other manipulations like the placement of framing statements. ${ }^{66}$ Media coverage of health data sharing is influential. ${ }^{67,68}$ Despite best intentions it is impossible to avoid framing effects entirely, ${ }^{28}$ so those presenting information should be aware of these whilst presenting accurately the risks and benefits of data sharing/linkage.

During COVID-19, despite press coverage ${ }^{32}$ of an enforced increase in sharing, ${ }^{31,33}$ support for sharing/linkage increased - but only for some already-favoured destinations. Publicity regarding NHS care ${ }^{69}$ and research regarding COVID-19 $9^{70,71}$ may have driven the increase in support for sharing with the NHS, universities, and research charities.

\subsection{Conclusions}

Participants supported a central system for patients to control the uses of their data, and likewise a single NHS mechanism to sign up for active research participation. There is a trade-off between the scientific desirability of everyone contributing de-identified data, including to avoid bias, ${ }^{72,73}$ and the desirability of individual control over data use ${ }^{74} \mathrm{~A}$ reasonable balance might be a central system to opt out from identifiable clinical use, identifiable (s251) research use, or de-identified research use of one's data, and to opt in for participatory research. This would complement efforts to improve people's access to their own data. ${ }^{75}$

The majority support observed for clinical sharing without explicit consent perhaps makes such sharing reasonable as a default (opt-out) position, given the potential advantages for many people's own care, subject to strict IG rules (who has access, when). However, a significant minority opposed this, mandating at least a public information campaign about opt-outs if this were to occur.

There was strong net support for NHS, academic, and charity researchers accessing de-identified health data. A standard method is a trusted research environment (TRE). ${ }^{24,57,76,77}$ Approved researchers come "into" the secure environment to interact with relevant data (e.g. pseudonymised; Fig.1). After analysis, aggregation, and other statistical disclosure control (SDC) ${ }^{78}$ results go "out" for publication (Fig.1).

In contrast, respondents did not support research sharing to private companies. Some have suggested this is addressable in part by public education. ${ }^{11}$ We suggest respecting public preference, and not giving 
medRxiv preprint doi: https://doi.org/10.1101/2021.07.19.21260635; this version posted July 19, 2021. The copyright holder for this preprint (which was not certified by peer review) is the author/funder, who has granted medRxiv a license to display the preprint in perpetuity.

It is made available under a CC-BY 4.0 International license.

commercial organisations direct access to patient-level NHS data for research, even de-identified, without consent. (This is distinct from the common NHS practice of employing companies, such as EHR software providers, to manage NHS data securely for clinical purposes.) We think that this does not rule out all industrial research uses of data, which could happen according to at least three methods. The first is via consent, as for commercial treatment trials. Secondly, companies could collaborate with NHS/academic researchers. For example, an artificial intelligence company could provide an untrained algorithm; NHS staff could train it on patient-level data; the company could receive a trained algorithm back whilst never having access to the data (assuming verification that the algorithm cannot "embed" detailed data features during training). Thirdly, methods exist whereby software queries come "in" to the TRE, and semi-automatic or automatic SDC occurs before results go "out". ${ }^{79-81}$ This allows research to take place without researchers having access to patient-level data, and can also support "federated" queries across sites. Data that have undergone suitable SDC (e.g. aggregation) can be published, and are therefore suitable for industrial access if desired. Regardless, as our participants commented, the NHS might charge for such access, ${ }^{11,82}$ and full transparency is essential. Formal, consultation-based standards governing this NHS-commercial interface would be desirable.

Governance of UK health data must be transparent and reflect the views of patients. ${ }^{11,16}$ As the UK Government seeks to change data legislation ${ }^{83}$ and emphasize health data in its science strategy, ${ }^{84}$ we hope this study contributes to the conversation.

\section{Acknowledgements}

We thank all those who took part in the study and gave their views. We thank all the investigators, local collaborators, local NIHR CRN staff, and health care staff across the UK who supported the study. We thank also Elizabeth Rotherham (research advisory group member) for help with design; Nicola Gleadle for practical support; Jane Gaffa, Rachel Kyd, and Mary-Beth Sherwood for Research and Development support; Sally-Anne Hurford and Ruth Hudson for NIHR CRN advice; Chess Denman for investigator approval; Laura Marshall for CPFT publicity; Hannah Clarke for helpful comments; REC and HRA staff for ethical and regulatory approvals; the Cambridge Autism Research Database for additional publicity.

\section{Author contributions}

RNC conceived the study. LAJ, JRN, PHA, MRG, MP and RNC designed it (with ER). LAJ coordinated its execution. JMF advised on REDCap implementation and execution. RNC, LAJ, and JMF had access to the original data; the final data set is public. RNC analysed the data. RNC and LAJ drafted the manuscript. All authors edited the manuscript and approved submission.

\section{Funding}

Supported by the UK Medical Research Council (Mental Health Data Pathfinder award MC_PC_17213 to RNC). Recruitment was supported by the NIHR CRN and the REDCap installation was supported in part by the NIHR Cambridge Biomedical Research Centre (BRC-1215-20014); the views expressed are those of the authors and not necessarily those of the NHS, the NIHR, or the Department of Health and Social Care.

\section{Competing interests}

The authors report no competing interests. 
medRxiv preprint doi: https://doi.org/10.1101/2021.07.19.21260635; this version posted July 19, 2021. The copyright holder for this preprint (which was not certified by peer review) is the author/funder, who has granted medRxiv a license to display the preprint in perpetuity.

It is made available under a CC-BY 4.0 International license .

\section{References}

1 UK. National Health Service Act 2006. 2006 https://www.legislation.gov.uk/ukpga/2006/41.

2 UK General Medical Council. Confidentiality: good practice in handling patient information. 2017 http://www.gmc-uk.org/guidance/ethical_guidance/confidentiality.asp.

3 Caldicott F. Information: To share or not to share? The Information Governance Review. 2013; published online March. https://www.gov.uk/government/publications/the-information-governance-review.

4 UK Department of Health. Confidentiality: NHS Code of Practice. 2003; published online Nov. https://www.gov.uk/government/publications/confidentiality-nhs-code-of-practice.

5 UK. Data Protection Act 2018. 2018 http://www.legislation.gov.uk/ukpga/2018/12/contents/enacted.

6 European Parliament and Council. Regulation (EU) 2016/679 (General Data Protection Regulation). Off J Eur Union 2016; L119: 1-88.

7 UK. Mental Capacity Act 2005. 2005 https://www.legislation.gov.uk/ukpga/2005/9/contents.

8 Coulter A. Patient trust in plans to share primary care data. BMJ 2021; 373: n1413.

9 NHS England. The NHS Constitution for England. 2015; published online July 27. https:/www.gov.uk/government/publications/the-nhs-constitution-for-england.

10 Culnane C, Rubinstein BIP, Teague V. Health Data in an Open World. ArXiv171205627 Cs 2017; published online Dec 15. http://arxiv.org/abs/1712.05627.

11 Ghafur S, Fontana G, Halligan J, O'Shaughnessy J, Darzi A. NHS Data: Maximising its impact on the health and wealth of the United Kingdom. Imperial College London, 2020 https://doi.org/10.25561/76409.

12 National Data Guardian for Health and Care. Review of Data Security, Consent and Opt-Outs. 2016. https://www.gov.uk/government/uploads/system/uploads/attachment_data/file/535024/data-securityreview.PDF.

13 NHS England. New local health and care partnerships could save lives. 2018. https://www.england.nhs.uk/2018/05/new-local-health-and-care-partnerships-could-save-lives/ (accessed Aug 23, 2019).

14 NHS England, Local Government Association. Local Health and Care Record Exemplars. 2018. https://www.england.nhs.uk/publication/local-health-and-care-record-exemplars/ (accessed Aug 23, 2019).

15 Aitken M, de St Jorre J, Pagliari C, Jepson R, Cunningham-Burley S. Public responses to the sharing and linkage of health data for research purposes: a systematic review and thematic synthesis of qualitative studies. BMC Med Ethics 2016; 17: 73.

16 Understanding Patient Data, Ada Lovelace Institute. Foundations of fairness: where next for NHS health data partnerships? $2020 \mathrm{https}$ ://understandingpatientdata.org.uk/sites/default/files/2020-03/Foundations \%20of\%20Fairness\%20-\%20Summary\%20and\%20Analysis.pdf (accessed April 20, 2020).

17 Hopkins H, Kinsella S, van Mil A. Foundations of fairness: views on uses of NHS patients' data and NHS operational data. Hopkins Van Mil: Creating Conditions Ltd, 2020

https://understandingpatientdata.org.uk/sites/default/files/2020-03/Foundations\%20of\%20Fairness $\% 20$ \%20Full\%20Research\%20Report.pdf (accessed April 20, 2020). 
medRxiv preprint doi: https://doi.org/10.1101/2021.07.19.21260635; this version posted July 19, 2021. The copyright holder for this preprint (which was not certified by peer review) is the author/funder, who has granted medRxiv a license to display the preprint in perpetuity.

It is made available under a CC-BY 4.0 International license .

18 Understanding Patient Data. Public attitudes to patient data use: a summary of existing research. 2018. https://understandingpatientdata.org.uk/sites/default/files/2019-05/Public\%20attitudes\%20key\%20themes \%200.pdf (accessed Aug 23, 2019).

19 Stockdale J, Cassell J, Ford E. 'Giving something back': A systematic review and ethical enquiry into public views on the use of patient data for research in the United Kingdom and the Republic of Ireland. Wellcome Open Res 2018; 3: 6.

20 Aitken M, McAteer G, Davidson S, Frostick C, Cunningham-Burley S. Public Preferences regarding Data Linkage for Health Research: A Discrete Choice Experiment. Int J Popul Data Sci 2018; 3: 429.

21 Ghafur S, Van Dael J, Leis M, Darzi A, Sheikh A. Public perceptions on data sharing: key insights from the UK and the USA. Lancet Digit Health 2020; 2: e444-6.

22 Henderson C, Evans-Lacko S, Thornicroft G. Mental Illness Stigma, Help Seeking, and Public Health Programs. Am J Public Health 2013; 103: 777-80.

23 Piotrowski P, Gondek TM, Królicka-Deręgowska A, Misiak B, Adamowski T, Kiejna A. Causes of mortality in schizophrenia: An updated review of European studies. Psychiatr Danub 2017; 29: 108-20.

24 Downs JM, Ford T, Stewart R, et al. An approach to linking education, social care and electronic health records for children and young people in South London: a linkage study of child and adolescent mental health service data. BMJ Open 2019; 9: e024355.

25 Sterckx S, Rakic V, Cockbain J, Borry P. 'You hoped we would sleep walk into accepting the collection of our data': controversies surrounding the UK care.data scheme and their wider relevance for biomedical research. Med Health Care Philos 2015; published online Aug 18. DOI:10.1007/s11019-015-9661-6.

26 Powles J, Hodson H. Google DeepMind and healthcare in an age of algorithms. Health Technol 2017; : 117.

27 Gayle D. GPs urged to refuse to hand over patient details. The Guardian. 2021; published online June 1. https://www.theguardian.com/society/2021/jun/01/gps-urged-to-refuse-to-hand-over-patient-details-tonhs-digital (accessed June 29, 2021).

28 Tversky A, Kahneman D. The framing of decisions and the psychology of choice. Science 1981; 211: 453-8.

29 Harris PA, Taylor R, Thielke R, Payne J, Gonzalez N, Conde JG. Research electronic data capture (REDCap)--a metadata-driven methodology and workflow process for providing translational research informatics support. J Biomed Inform 2009; 42: 377-81.

30 Higher Education Funding Council for England, Research Councils UK, Universities UK, Wellcome Trust. Concordat on Open Research Data. 2016.

https://www.ukri.org/files/legacy/documents/concordatonopenresearchdata-pdf/.

31 Department for Health and Social Care, Hancock M. Coronavirus (COVID-19): notification to organisations to share information. 2020; published online April 1.

https://www.gov.uk/government/publications/coronavirus-covid-19-notification-of-data-controllers-toshare-information.

32 Lewis P, Conn D, Pegg D. UK government using confidential patient data in coronavirus response. The Guardian. 2020; published online April 12. https://www.theguardian.com/world/2020/apr/12/ukgovernment-using-confidential-patient-data-in-coronavirus-response (accessed April 12, 2020).

33 NHS Digital. SCR coronavirus (COVID-19) supplementary privacy notice. NHS Digit. 2020; published online April 20. https://digital.nhs.uk/services/summary-care-records-scr/scr-coronavirus-covid-19supplementary-privacy-notice (accessed June 27, 2021). 
medRxiv preprint doi: https://doi.org/10.1101/2021.07.19.21260635; this version posted July 19, 2021. The copyright holder for this preprint (which was not certified by peer review) is the author/funder, who has granted medRxiv a license to display the preprint in perpetuity.

It is made available under a CC-BY 4.0 International license .

34 R Core Team. R: A language and environment for statistical computing. Vienna, Austria: R Foundation for Statistical Computing, 2019 http://www.R-project.org/.

35 Cardinal RN, Aitken MRF. ANOVA for the Behavioural Sciences Researcher. Mahwah, N.J: L. Erlbaum, 2006.

36 Myers JL, Well AD. Research design and statistical analysis, Second. Mahwah, New Jersey: Lawrence Erlbaum Associates, 2003.

37 Maxwell SE, Delaney HD. Designing experiments and analyzing data: a model comparison perspective, Second. Mahwah, New Jersey: Lawrence Erlbaum Associates, 2004.

38 NHS Scotland. Intra NHS Scotland Information Sharing Accord. 2010.

https://www.informationgovernance.scot.nhs.uk/wp-content/uploads/2020/06/2020-06-17-Intra-NHSScotland-Sharing-Accord-v2.0.pdf.

39 Morris LMM, Brown C, Williamson M, Wyatt JC. The Scottish Emergency Care Summary--an evaluation of a national shared record system aiming to improve patient care: technology report. Inform Prim Care 2012; 20: 41-9.

40 NIDirect. Northern Ireland Electronic Care Record (NIECR) | nidirect. 2015; published online Dec 16. https://www.nidirect.gov.uk/articles/northern-ireland-electronic-care-record-niecr (accessed July 6, 2021).

41 Greenhalgh T, Stramer K, Bratan T, Byrne E, Russell J, Potts HWW. Adoption and non-adoption of a shared electronic summary record in England: a mixed-method case study. BMJ 2010; 340: c3111.

42 Auditor General for Wales. Informatics systems in NHS Wales. 2018; published online Jan 11. https://senedd.wales/laid\%20documents/agr-ld11353/agr-ld11353-e.pdf.

43 Atkin C, Crosby B, Dunn K, et al. Perceptions of anonymised data use and awareness of the NHS data opt-out amongst patients, carers and healthcare staff. Res Involv Engagem 2021; 7: 40.

44 UK. Health and Social Care (Safety and Quality) Act 2015. 2015 http://www.legislation.gov.uk/ukpga/2015/28/contents.

45 nef (The New Economics Foundation), Centre for Science Education at Sheffield Hallam University. Who sees what: exploring public views on personal electronic health records. 2010 https://neweconomics.org/uploads/files/2cb17ab59382fe7c67_bfm6bdoas.pdf.

46 NHS. National Data Opt-out: Factsheet 2 - When it applies. 2018. https://digital.nhs.uk/binaries/content/assets/website-assets/services/national-data-opt-out-programme/ guidance-for-health-and-care-staff/nhs-factsheet-2-23052018.pdf (accessed July 26, 2019).

47 NHS Digital. Understanding the national data opt-out. 2019. https://web.archive.org/web/20200804083843/https://digital.nhs.uk/services/national-data-opt-out/ understanding-the-national-data-opt-out.

48 UK. The Health Service (Control of Patient Information) Regulations 2002. 2002 http://www.legislation.gov.uk/uksi/2002/1438/contents/made.

49 Beange I, Kirkham EJ, Fletcher-Watson S, et al. Using a knowledge exchange event to assess study participants' attitudes to research in a rapidly evolving research context. Wellcome Open Res 2020; 5: 24.

50 Chico V, Hunn A, Taylor M. Public views on sharing anonymised patient-level data where there is a mixed public and private benefit. Health Research Authority; University of Sheffield School of Law, 2019. 
medRxiv preprint doi: https://doi.org/10.1101/2021.07.19.21260635; this version posted July 19, 2021. The copyright holder for this preprint (which was not certified by peer review) is the author/funder, who has granted medRxiv a license to display the preprint in perpetuity.

It is made available under a CC-BY 4.0 International license .

51 Helm T. Revealed: how drugs giants can access your health records. The Guardian 2020; published online Feb 8. https://www.theguardian.com/technology/2020/feb/08/fears-over-sale-anonymous-nhs-patient-data (accessed Feb 8, 2020).

52 Gazard B, Chui Z, Harber-Aschan L, et al. Barrier or stressor? The role of discrimination experiences in health service use. BMC Public Health 2018; 18: 1354.

$53 \mathrm{Wu}$ Z, Schimmele CM. Perceived religious discrimination and mental health. Ethn Health 2019; : 1-18.

54 Luchenski SA, Reed JE, Marston C, Papoutsi C, Majeed A, Bell D. Patient and public views on electronic health records and their uses in the United kingdom: cross-sectional survey. J Med Internet Res 2013; 15: e160.

55 Haeusermann T, Greshake B, Blasimme A, Irdam D, Richards M, Vayena E. Open sharing of genomic data: Who does it and why? PloS One 2017; 12: e0177158.

56 SteelFisher GK, Findling MG, Bleich SN, et al. Gender discrimination in the United States: Experiences of women. Health Serv Res 2019; 54 Suppl 2: 1442-53.

57 Lyons RA, Jones KH, John G, et al. The SAIL databank: linking multiple health and social care datasets. BMC Med Inform Decis Mak 2009; 9: 3.

58 Lyons J, Akbari A, Torabi F, et al. Understanding and responding to COVID-19 in Wales: protocol for a privacy-protecting data platform for enhanced epidemiology and evaluation of interventions. BMJ Open 2020; 10: e043010.

59 Hagger-Johnson G. Opportunities for longitudinal data linkage in Scotland. Scott Med J 2016; 61: 13645.

60 Thornicroft G, Mehta N, Clement S, et al. Evidence for effective interventions to reduce mental-healthrelated stigma and discrimination. Lancet Lond Engl 2016; 387: 1123-32.

61 Clement S, Schauman O, Graham T, et al. What is the impact of mental health-related stigma on helpseeking? A systematic review of quantitative and qualitative studies. Psychol Med 2015; 45: 11-27.

62 Gary FA. Stigma: barrier to mental health care among ethnic minorities. Issues Ment Health Nurs 2005; 26: 979-99.

63 Sangill C, Buus N, Hybholt L, Berring LL. Service user's actual involvement in mental health research practices: A scoping review. Int J Ment Health Nurs 2019; 28: 798-815.

64 UK. Equality Act 2010. 2010. https://www.legislation.gov.uk/ukpga/2010/15/contents (accessed July 5, 2021).

65 Tully MP, Bozentko K, Clement S, et al. Investigating the Extent to Which Patients Should Control Access to Patient Records for Research: A Deliberative Process Using Citizens' Juries. J Med Internet Res 2018; 20: e112.

66 Sakshaug JW, Schmucker A, Kreuter F, Couper MP, Singer E. The Effect of Framing and Placement on Linkage Consent. Public Opin Q 2019; 83: 289-308.

67 Gollust SE, Fowler EF, Niederdeppe J. Television News Coverage of Public Health Issues and Implications for Public Health Policy and Practice. Annu Rev Public Health 2019; 40: 167-85.

68 Ford E, Kazempour Y, Cooper MJF, Katikireddi SV, Boyd A. Media content analysis of general practitioners' reactions to care.data expressed in the media: what lessons can be learned for future NHS data-sharing initiatives? BMJ Open 2020; 10: e038006. 
medRxiv preprint doi: https://doi.org/10.1101/2021.07.19.21260635; this version posted July 19, 2021. The copyright holder for this preprint (which was not certified by peer review) is the author/funder, who has granted medRxiv a license to display the preprint in perpetuity.

It is made available under a CC-BY 4.0 International license .

69 Prime Minister's Office. PM address to the nation on coronavirus: 23 March 2020. 2020; published online March 23. https://www.gov.uk/government/speeches/pm-address-to-the-nation-on-coronavirus-23-march2020 (accessed March 23, 2020).

70 RECOVERY Collaborative Group, Horby P, Lim WS, et al. Dexamethasone in Hospitalized Patients with Covid-19. N Engl J Med 2021; 384: 693-704.

71 Horby P, Lim WS, Emberson J, et al. Effect of Dexamethasone in Hospitalized Patients with COVID-19 Preliminary Report. medRxiv 2020; : 2020.06.22.20137273.

72 Elwood JM, Marshall RJ, Tin ST, Barrios MEP, Harvey VJ. Bias in survival estimates created by a requirement for consent to enter a clinical breast cancer registry. Cancer Epidemiol 2019; 58: 178-83.

73 Morgan K, Page N, Brown R, et al. Sources of potential bias when combining routine data linkage and a national survey of secondary school-aged children: a record linkage study. BMC Med Res Methodol 2020; 20: 178 .

74 Kariotis T, Ball MP, Greshake Tzovaras B, et al. Emerging Health Data Platforms: From Individual Control to Collective Data Governance. 2020. DOI:10.1017/dap.2020.14.

75 Wyatt D, Lampon S, McKevitt C. Delivering healthcare's 'triple aim': electronic health records and the health research participant in the UK National Health Service. Sociol Health Illn 2020; 42: 1312-27.

76 UK Office for National Statistics. ONS Secure Research Service (SRS). 2019. https://www.ons.gov.uk/aboutus/whatwedo/paidservices/virtualmicrodatalaboratoryvml (accessed July 23, 2019).

77 Stewart R, Soremekun M, Perera G, et al. The South London and Maudsley NHS Foundation Trust Biomedical Research Centre (SLAM BRC) case register: development and descriptive data. BMC Psychiatry 2009; 9: 51.

78 Griffiths E, Greci C, Kotrotsios Y, et al. Handbook on Statistical Disclosure Control for Outputs. 2019; published online July. https://ukdataservice.ac.uk/media/622521/thf_datareport_aw_web.pdf.

79 Williamson EJ, Walker AJ, Bhaskaran K, et al. Factors associated with COVID-19-related death using OpenSAFELY. Nature 2020; 584: 430-6.

80 Wolfson M, Wallace SE, Masca N, et al. DataSHIELD: resolving a conflict in contemporary bioscience-performing a pooled analysis of individual-level data without sharing the data. Int J Epidemiol 2010; 39: 1372-82.

81 Gaye A, Marcon Y, Isaeva J, et al. DataSHIELD: taking the analysis to the data, not the data to the analysis. Int J Epidemiol 2014; 43: 1929-44.

82 Fontana G, Ghafur S, Torne L, Goodman J, Darzi A. Ensuring that the NHS realises fair financial value from its data. Lancet Digit Health 2020; 2: e10-2.

83 UK Department of Health and Social Care. Data saves lives: reshaping health and social care with data (draft). GOV.UK. 2021; published online June 23. https://www.gov.uk/government/publications/datasaves-lives-reshaping-health-and-social-care-with-data-draft (accessed July 6, 2021).

84 UK Department for Business, Energy \& Industrial Strategy. Life Sciences Vision (policy paper). 2021; published online July 6 . https://assets.publishing.service.gov.uk/government/uploads/system/uploads/ attachment_data/file/1000030/life-sciences-vision.pdf. 
medRxiv preprint doi: https://doi.org/10.1101/2021.07.19.21260635; this version posted July 19, 2021. The copyright holder for this preprint (which was not certified by peer review) is the author/funder, who has granted medRxiv a license to display the preprint in perpetuity.

It is made available under a CC-BY 4.0 International license .

\section{Figure legends}

Figure 1. Classifying health data according to identifiability. At the "patient" level, the Venn diagram shows the overlaps between information that directly identifies a person, research identifiers (RIDs or pseudonyms), and health information, with simple examples. Anonymous health data may also existing in aggregated form, distinct from patient-level data; this aggregated form is the norm for public distribution. The level of identification risk and the research information governance requirements vary with the resulting categories of data, shown in the legend. All examples are fictional. (DOB, date of birth.)

Figure 2. (A) Understanding of how health data are shared identifiably without explicit consent for clinical purposes, and (B) preference as to what should happen. The denominator for percentages is the number of people who answered each question.

Figure 3. Participants' self-reported likelihood of sharing mental and physical health data without explicit consent for clinical purposes (identifiably) or research (de-identified), according to destination, nature (MH versus $\mathrm{PH}$ ), framing statement, and for research purposes also the level of detail (structured only versus with free text). The denominator for percentages is the number of people who answered each question. In plots $\mathrm{C}$, $\mathrm{F}$, and $\mathrm{H}$, the abscissa is the mean of responses coded as -2 very unlikely, -1 unlikely, 0 not sure, +1 likely, +2 very likely. Analyses were from models $\mathrm{C} 1$ and R1 as described in the Methods. (De-id., de-identified; MH, mental health; PH, physical health; \#\#\#\#, $p<10^{-5}$ for main effect of destination; $\dagger \dagger \dagger \dagger \dagger, p<10^{-5}$ for main effect of nature, with bar length showing mean difference between $\mathrm{MH}$ and $\mathrm{PH} ; * * p<0.01$ and $* * * * *$ $p<10^{-5}$ for framing $\times$ nature interaction, with bar showing the mean difference between "MH concern" and "neutral"; $\S \S \S \S, p<10^{-5}$, main effect of detail, comparing panel $\mathrm{F}$ with panel I, with bar length showing the mean difference between structured and free-text conditions.) See Supplementary Figure 4 for corresponding weighted analysis.

Figure 4. Participants' willingness for their NHS data to be linked to non-health data of different kinds for research. The denominator for percentages is the number of people who answered each question. See Supplementary Figure 5 for corresponding weighted analysis.

Figure 5. Change in preference in relation to the COVID-19 pandemic. (A) Clinical/identifiable data sharing, by destination. Dependent variable (preference for sharing) as for Figure 3C, now shown on the ordinate $(y)$ axis. (B) Research/de-identified data sharing, by detail (structured versus free text) and destination. Dependent variable as for Figure 3F,H. (C) Linkage for research, by non-NHS data source type. Dependent variable coded as -1 no, 0 not sure, +1 yes. (Error bars show \pm 1 SEM; $* * * * * p<10^{-5}$, **** $p<10^{-4}, * * * p<10^{-3}, * * p<10^{-2}, * p<0.05$ by two-sample $t$ test Šidák-corrected for multiple comparisons; NS, not significant; \#\#\#\# $p \lll 10^{-5}$, destination $\times$ pandemic interaction.)

Figure 6. Effect sizes for (A) clinical data sharing via statistical model C2, (B) research data sharing via model R2, and (C) linkage via model L2. These models include only those participants who supplied full demographic information, to allow analysis by demographics; compare Supplementary Figure 6 (all participants). Only those model terms with a significant $F$ test are shown. Effect sizes with $95 \%$ confidence intervals are shown for each level as uncorrected pairwise comparisons to a reference category within each term (note the difference in what is being tested pairwise versus the omnibus $F$ test for the term; see Supplementary Methods). $\bullet p<\alpha$; ○ NS.

Figure 7. Views on a national data sharing consent system. The denominator for percentages is the number of people who answered each question. See Supplementary Figure 7 for corresponding weighted analysis. 
medRxiv preprint doi: https://doi.org/10.1101/2021.07.19.21260635; this version posted July 19, 2021. The copyright holder for this preprint (which was not certified by peer review) is the author/funder, who has granted medRxiv a license to display the preprint in perpetuity.

It is made available under a CC-BY 4.0 International license .

Figure 1

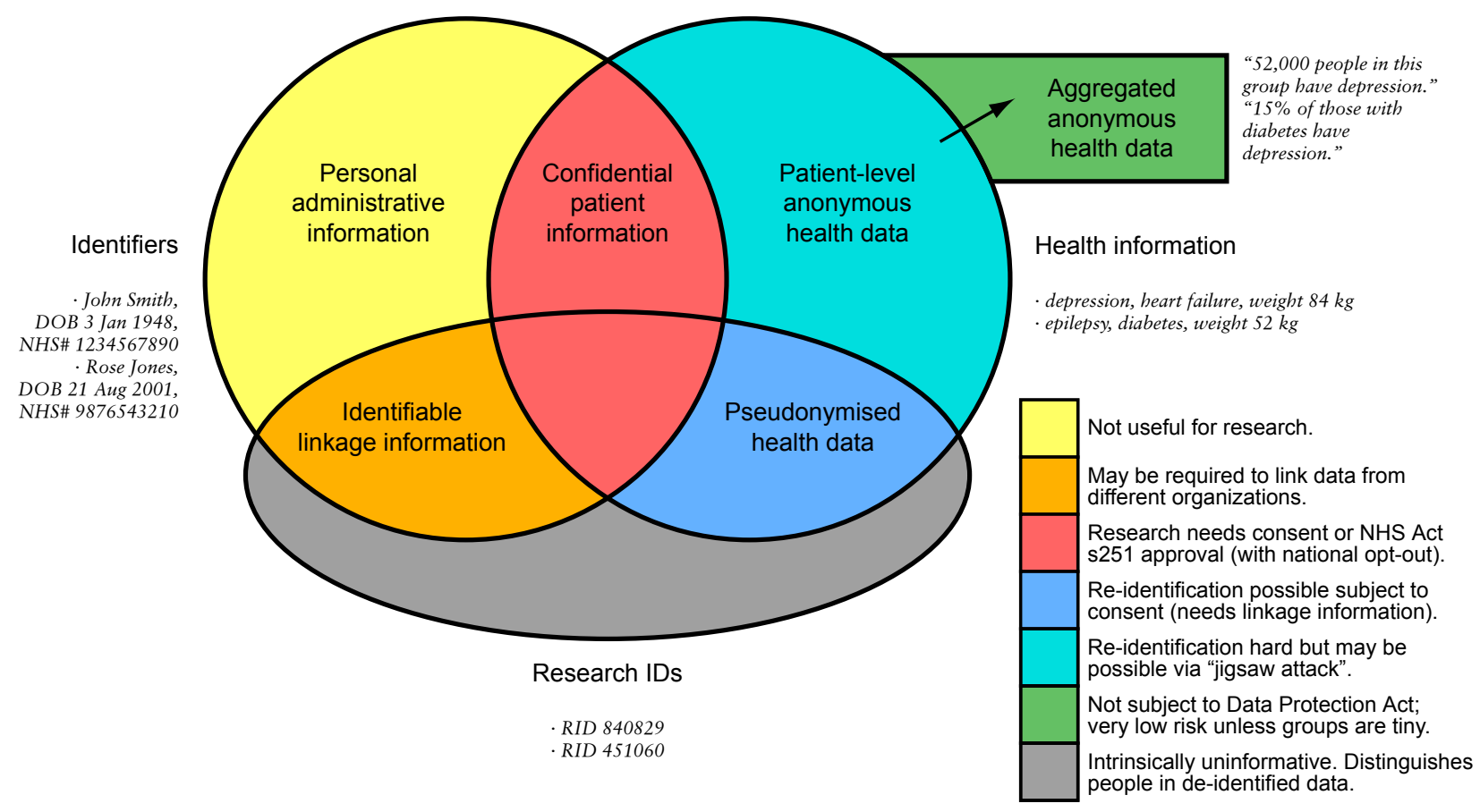


medRxiv preprint doi: https://doi.org/10.1101/2021.07.19.21260635; this version posted July 19,2021 . The copyright holder for this preprint (which was not certified by peer review) is the author/funder, who has granted medRxiv a license to display the preprint in perpetuity.

\section{Figure 2}

\section{A. Understanding of current clinical sharing}

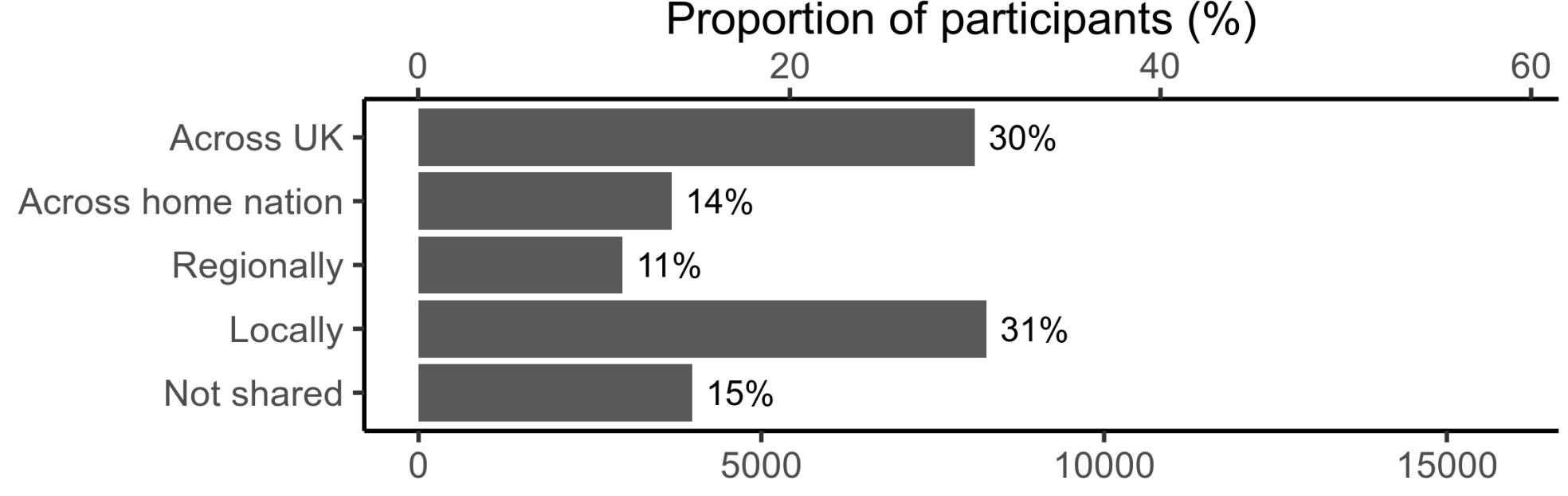

\section{B. Preference re clinical sharing without consent each time}

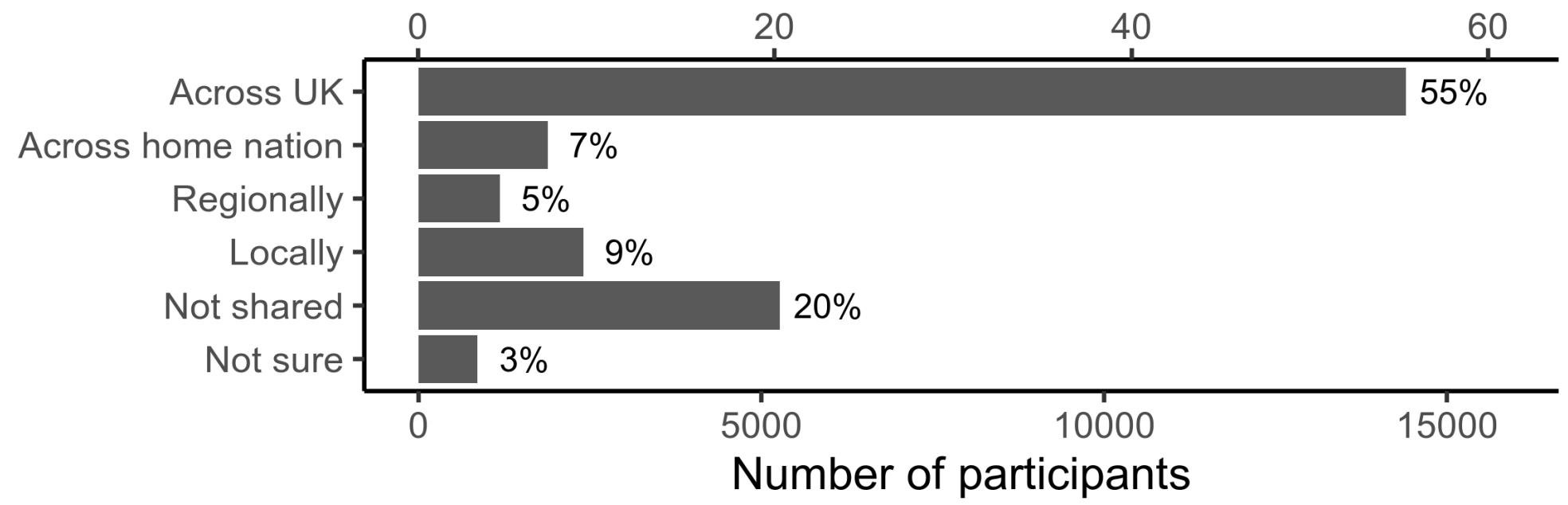


medRxiv preprint doi: https://doi.org/10.1101/2021.07.19.21260635; this version posted July 19, 2021. The copyright holder for this preprint (which was not certified by peer review) is the author/funder, who has granted medRxiv a license to display the preprint in perpetuity.

It is made available under a CC-BY 4.0 International license .

\section{Figure 3}

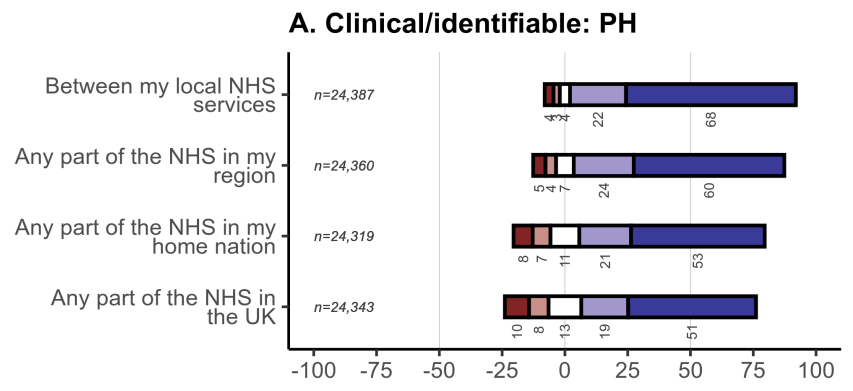

D. Research/de-id., structured: PH

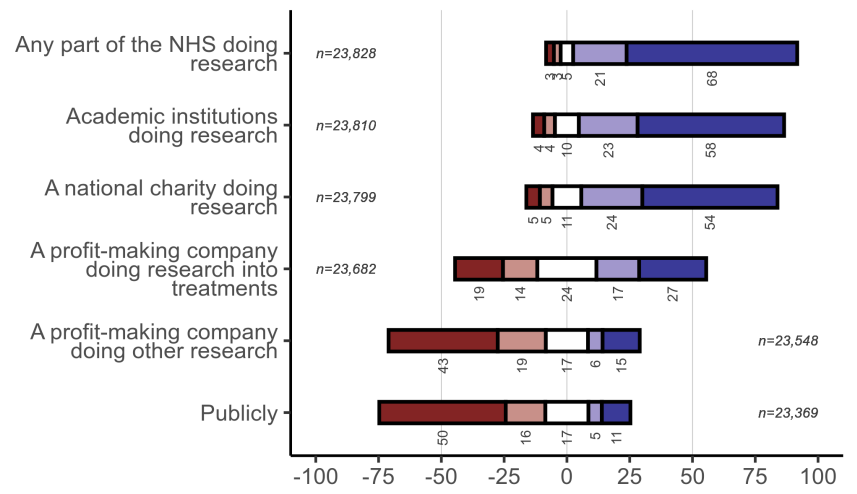

G. Research/de-id., free text: $\mathbf{P H}$

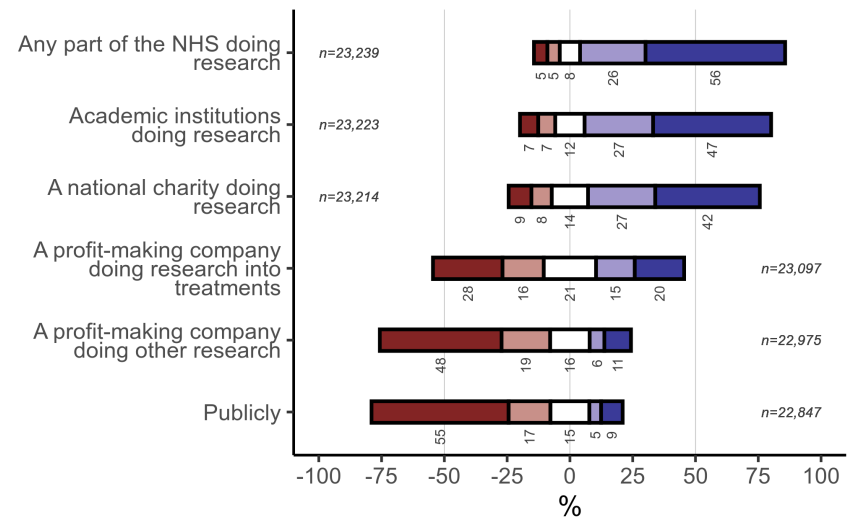

Very unlikely $\square$ Unlikely $\square$ Not sure
B. Clinical/identifiable: $\mathrm{MH}$

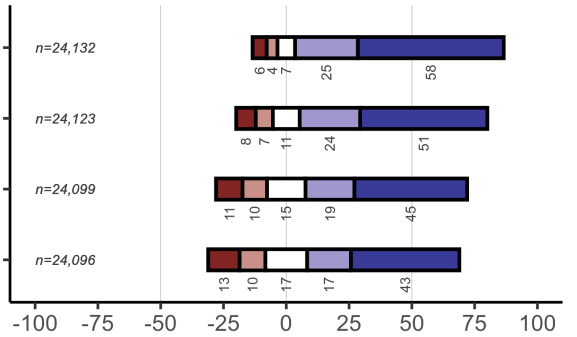

E. Research/de-id., structured: $M H$

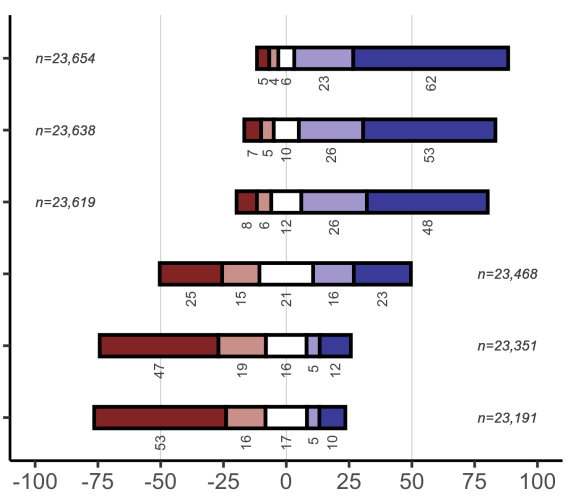

H. Research/de-id., free text: MH

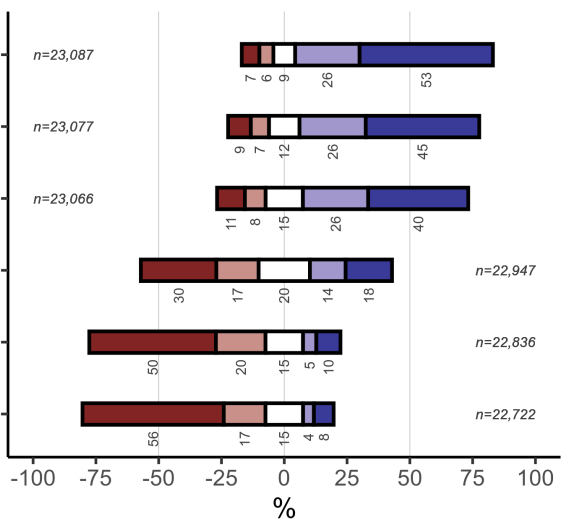

Likely $\square$ Very likely
C. Clinical/identifiable

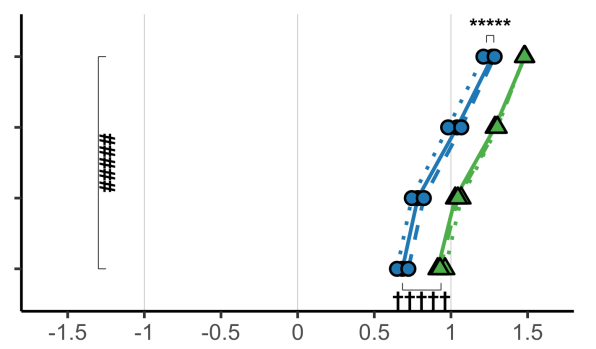

F. Research/de-id., structured

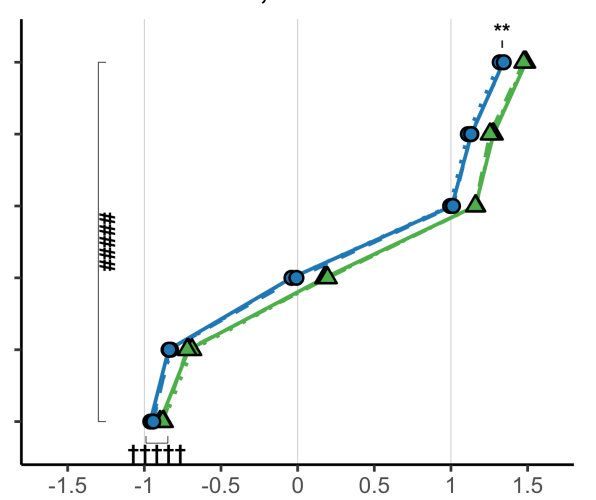

I. Research/de-id., free text

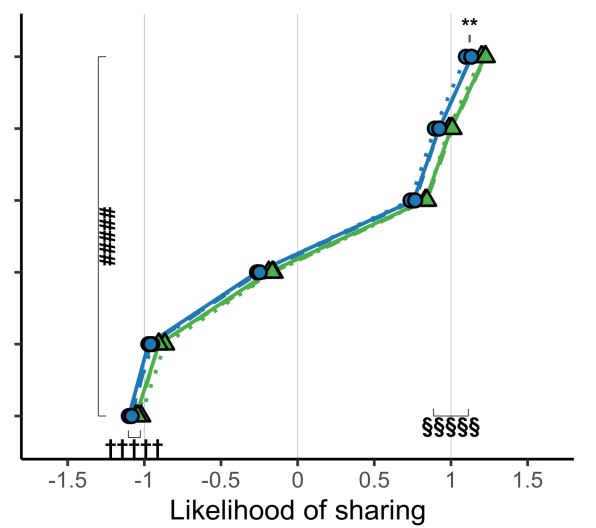


medRxiv preprint doi: https://doi.org/10.1101/2021.07.19.21260635; this version posted July 19, 2021. The copyright holder for this preprint (which was not certified by peer review) is the author/funder, who has granted medRxiv a license to display the preprint in perpetuity. It is made available under a CC-BY 4.0 International license.

\section{Figure 4}

\section{De-identified linkage to non-health data}

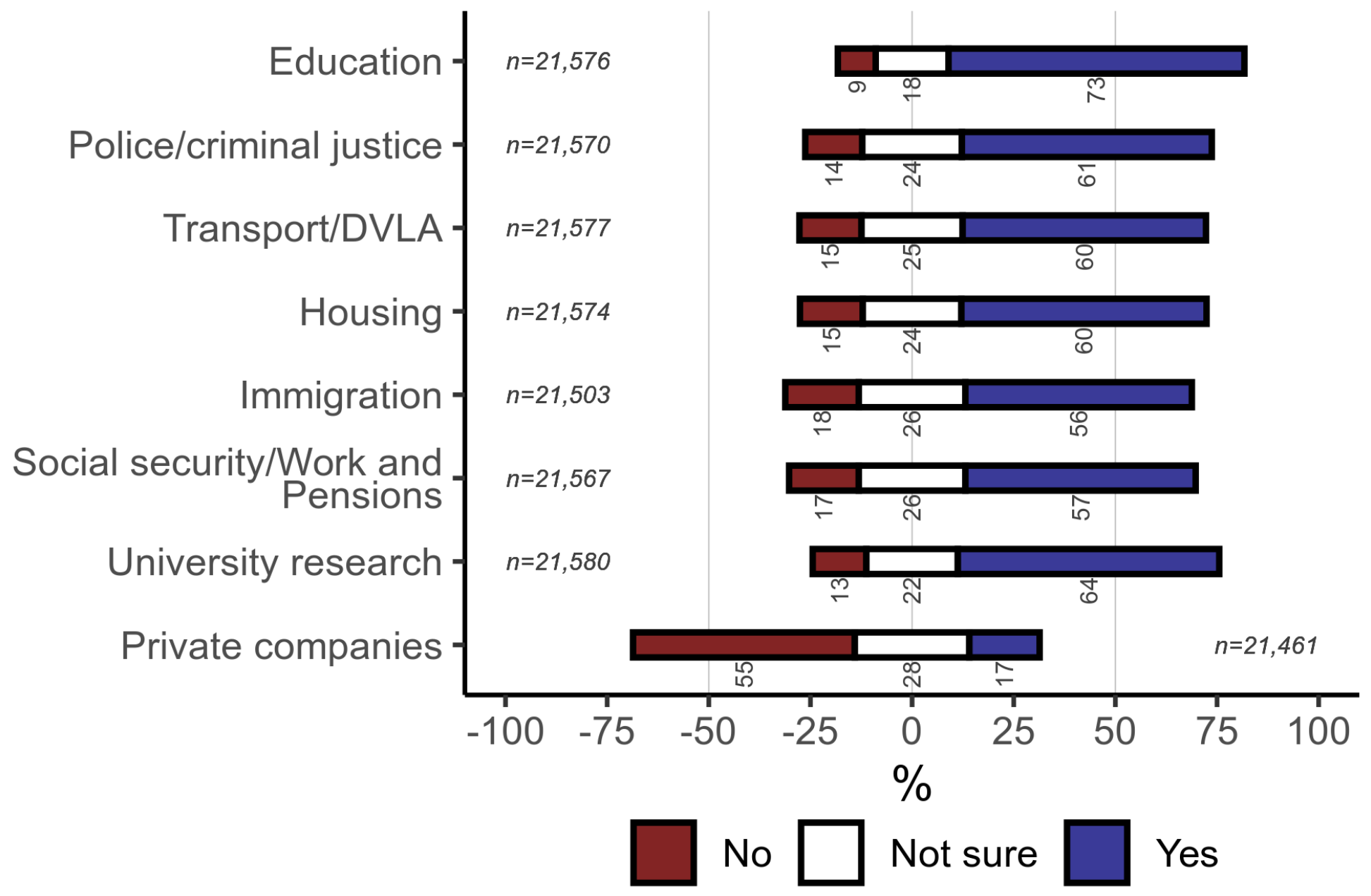


medRxiv preprint doi: https://doi.org/10.1101/2021.07.19.21260635; this version posted July 19, 2021. The copyright holder for this preprint (which was not certified by peer review) is the author/funder, who has granted medRxiv a license to display the preprint in perpetuity.

It is made available under a CC-BY 4.0 International license .

\section{Figure 5}

A. Clinical/identifiable

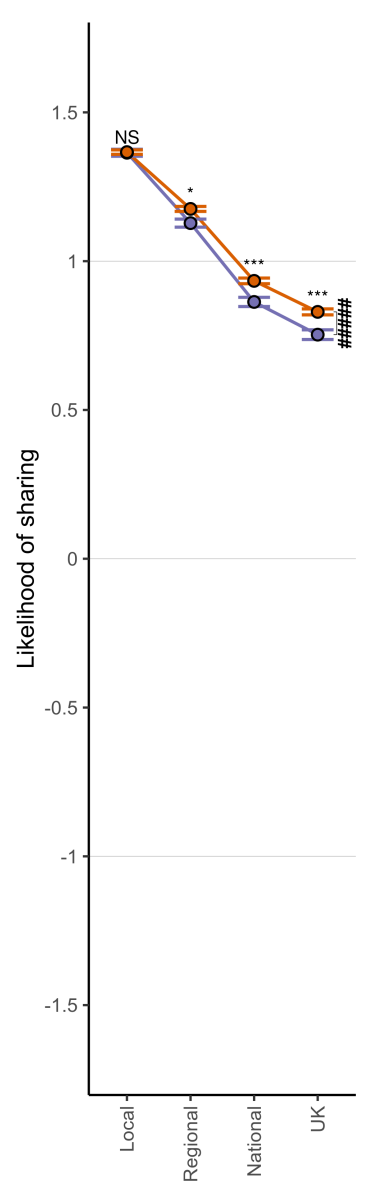

B. Research/de-identified

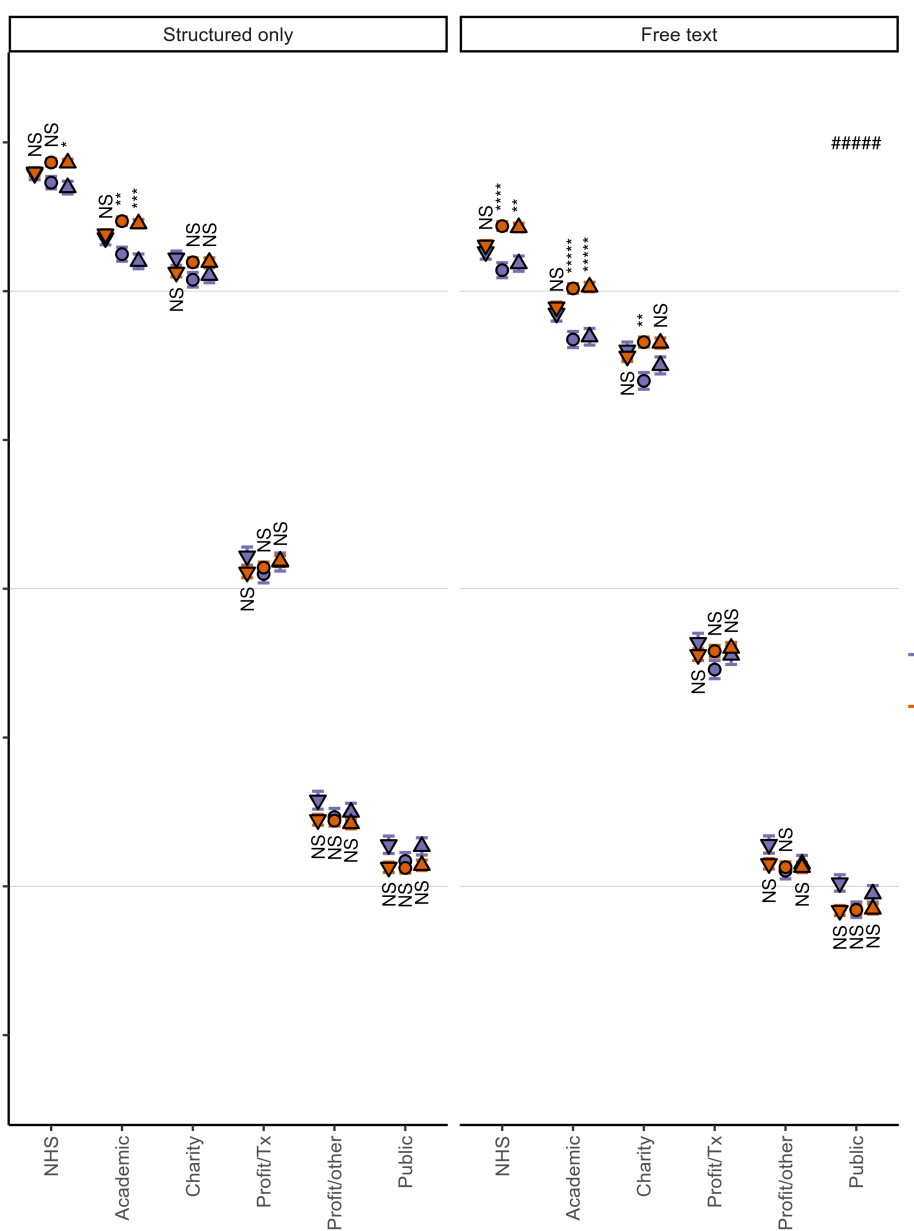

C. Linkage for research

$\nabla \quad \mathrm{MH}$ concern

- Neutral

$\triangle$ Holistic

- Before lockdown

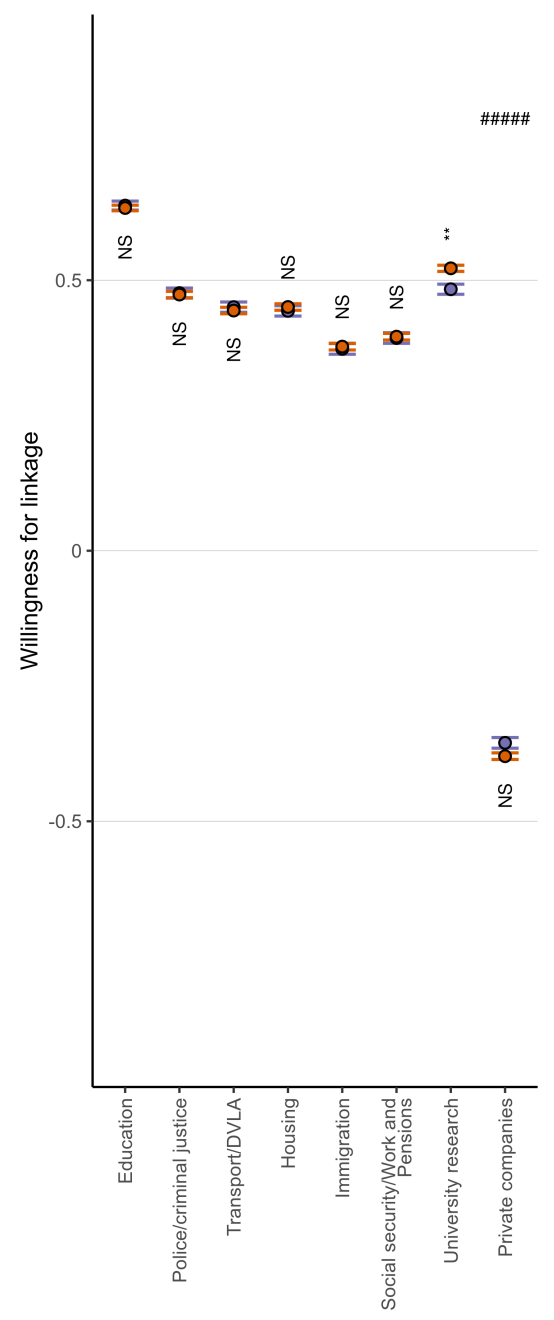



Model C2, $n=12370$

(Intercept) $\begin{aligned} & \text { (Intercept) } \\ & \text { Desto }\end{aligned}$

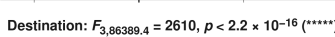

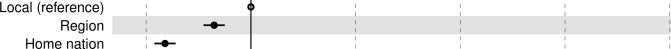
Nature: $F_{1,86394.1}=2630, p<2.2 \times 10^{-16}(-\cdots \cdot \cdots$

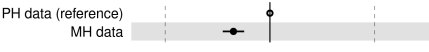
Age: $F_{6,12331.4}=4.49, p=1.84 \times 10^{-5}(\cdots \cdots$

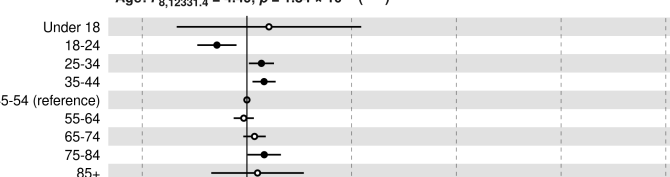
$\stackrel{\circ}{\longrightarrow}$ Gender: $F_{1,123327}=46.3, p=1.05 \times 10^{-11}(\cdots \cdots$ Ethnicity: $F_{1,12337,1}=62.6, p=2.76 \times 10^{-15}(\cdots \cdots \cdots)$

$\begin{array}{c:c:c}\begin{array}{c}\text { White (reference)e } \\ \text { Other ethnicity }\end{array} & \rightarrow & 0\end{array}$ Education: $F_{4,12335,2}=5.23, p=0.00033\left({ }^{\prime \prime \prime}\right)$

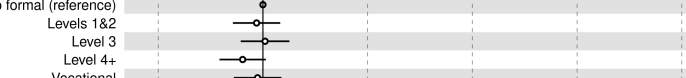
Religion: $F_{2,12332.8}=3.6, p=0.0274\left(c^{\circ}\right.$

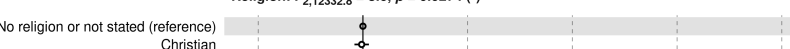

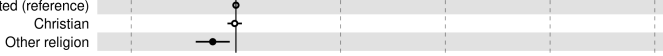
MH experience: $F_{1,12331.8}=10.4, p=0.00129$

\begin{tabular}{c|c|c|c|c|} 
No MH experience (réterence) \\
MH experience
\end{tabular} Destination $\times$ Nature: $F_{3,86387.7}=9.33, p=3.67 \times 10^{-6}(\cdots \cdots \cdot)$

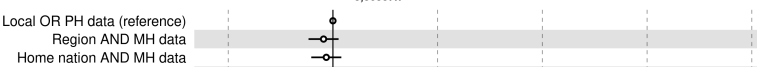

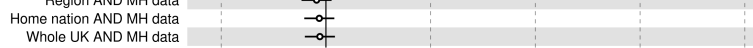
Nature $\times$ Framing: $F_{2,86394,9}=43.5, p<2.2 \times 10-16(-\cdots \cdot \cdots)$

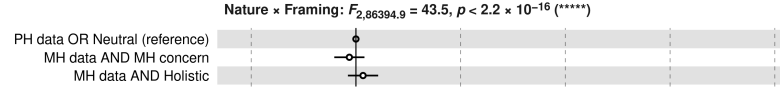
Destination $\times$ Pandemic: $F_{3,06399.4}=7.95, p=2.68 \times 10^{-5}(\mathrm{~m} m$

$\begin{gathered}\text { Local OR Beforer lockdown (reterence) } \\ \text { Regioin AND After lockdown }\end{gathered}$
Who

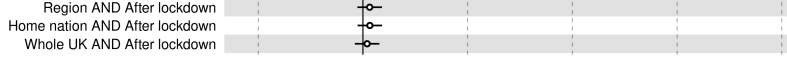
Nature $\times$ MH experience: $F_{1,36396.4}=13.6, p=0.000231($ (")

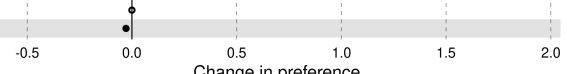

B. Research, participants with demographics

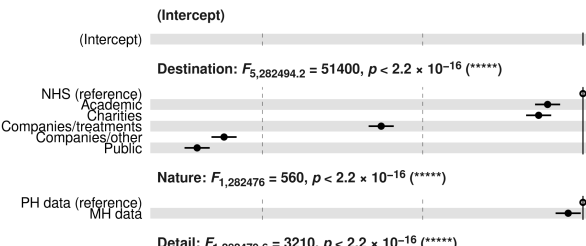

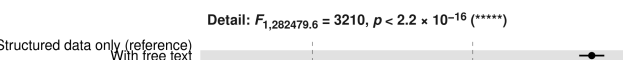

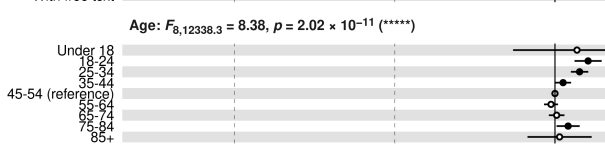

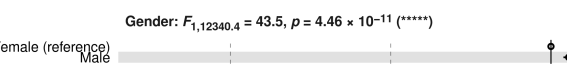

Ethnicity: $F_{1,12337.6}=10.2, p=0.00139\left({ }^{(*)}\right)$
White (retererencel

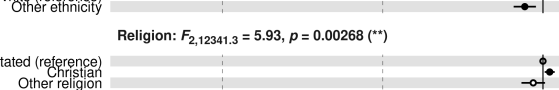
Nation: $F_{3,12332.5}=3.56, p=0.0137(")$

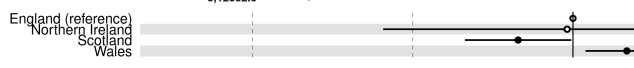

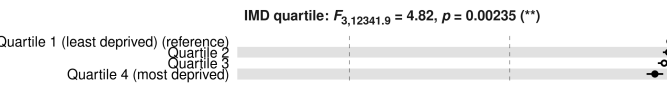

NS-SEC: $F_{4,12348.1}=2.75, p=0.0264^{(1)}$

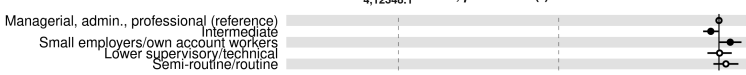

Destination $\times$ Nature: $F_{5,282466.1}=8.16, p=1.04 \times 10^{-7}(\cdots \cdots)$

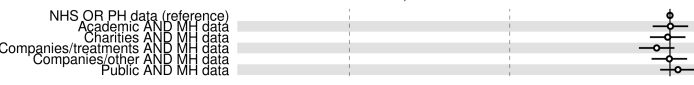
Destination $\times$ Detail: $F_{5,2828467.4}=29.1, p<2.2 \times 10^{-16},(\cdots \cdot \cdots$

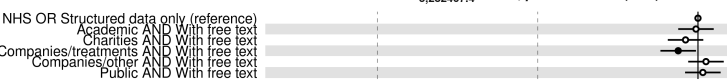

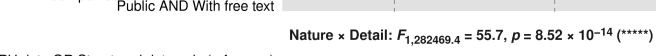

PH data OR Structured data only (reference)

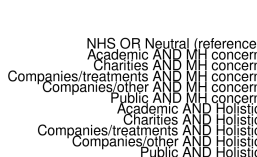

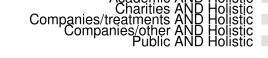

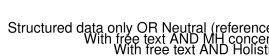

$$
\text { ictic }
$$

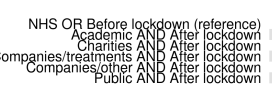

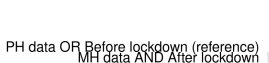

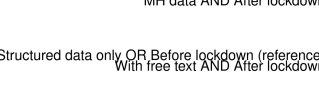

PH data OR N N MH M L experiencere (reterence)

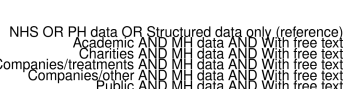

Destination $\times$ Framing: $F_{10,282949,3}=2.4, p=0.00757$ (")

\section{$\AA_{0-}^{-}$}

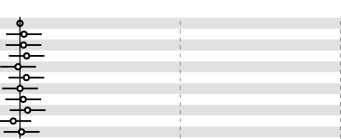

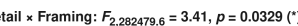

$$
\stackrel{\circ=}{a=-}
$$

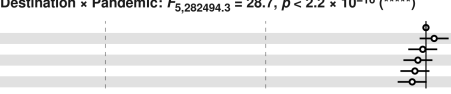

Nature $\times$ Pandemic: $F_{1,222478.1}=5.21, p=0.0224\left(c^{\circ}\right.$

Detail $\times$ Panden $\quad F_{120}$

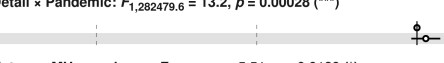

(1)

Destination $\times$ Nature $\times$ Detaili: $F_{5,282466}=4.03, p=0.00117$ (")

\section{Linkage, participants with demographics}

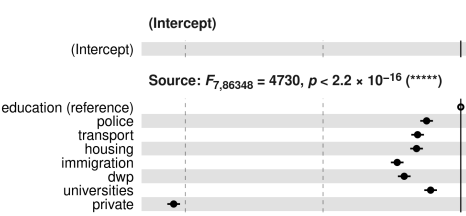

Age: $F_{8,12334.7}=18.5, p<2.2 \times 10^{-16}\left({ }^{\prime \prime} \cdot \cdots\right)$

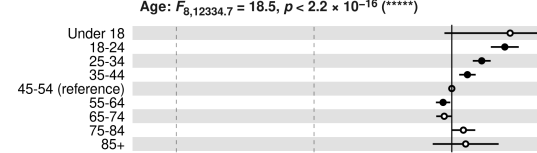

Ethnicity: $F_{1,12337.1}=18.3, p=1.92 \times 10^{-5}(+\cdots)$

White (reterence)
Oither eftrnicity

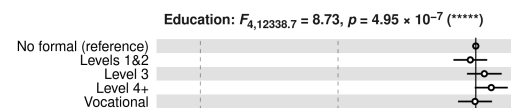

Sexuality: $\left.F_{1,12339.8}=3.91, \rho=0.04790^{\circ}\right)$

Heterosexual (retererence)

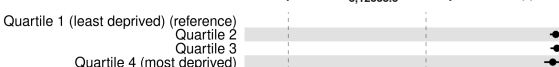

Source $x$ Pandemic: $F_{788398}=3.7, p=0.000529$

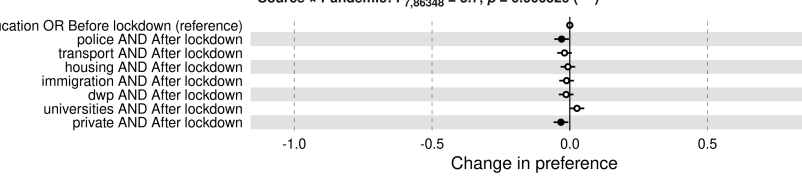


medRxiv preprint doi: https://doi.org/10.1101/2021.07.19.21260635; this version posted July 19, 2021. The copyright holder for this preprint (which was not certified by peer review) is the author/funder, who has granted medRxiv a license to display the preprint in perpetuity.

It is made available under a CC-BY 4.0 International license .

\section{Figure 7}

\section{A. Expressing choice nationally via...}

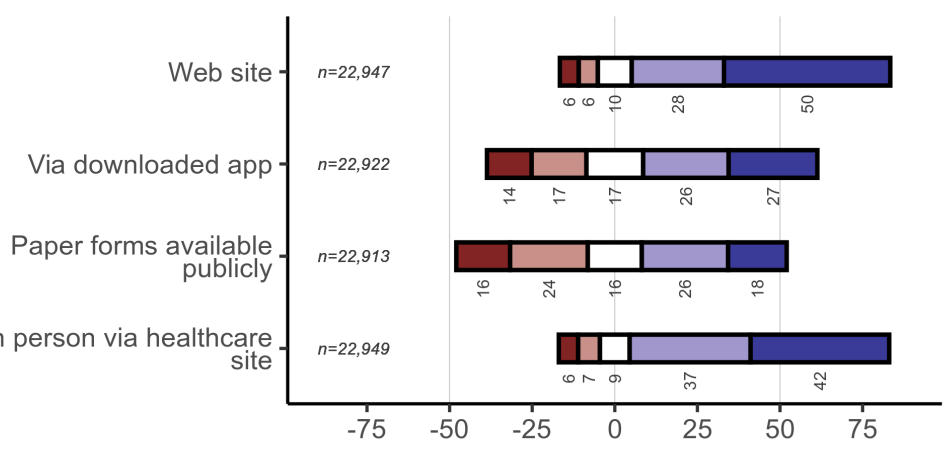

B. Expressing choice, if data held by...

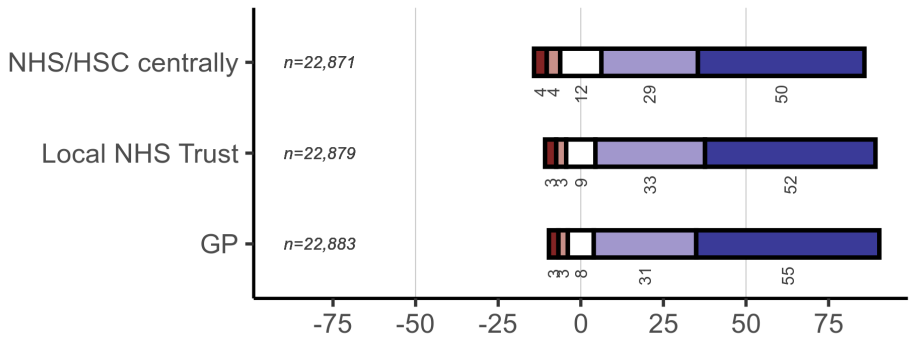

C. Changing preferences via...

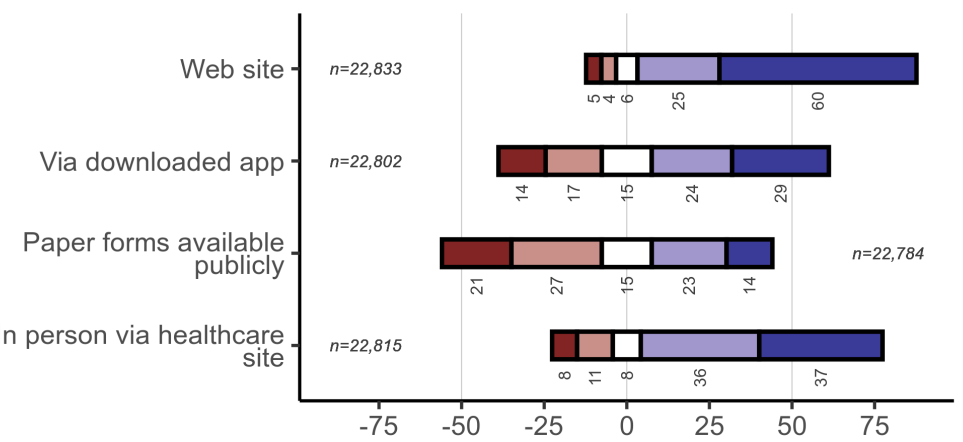

\section{Overall}

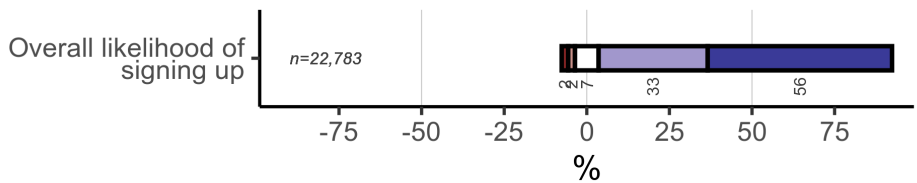

\begin{tabular}{l}
$\square$ Very unlikely \\
\hline$\square$ Unlikely \\
\hline$\square$ Not sure \\
\hline$\square$ Likely \\
Very likely
\end{tabular}

\section{E. Web sites for research participation}

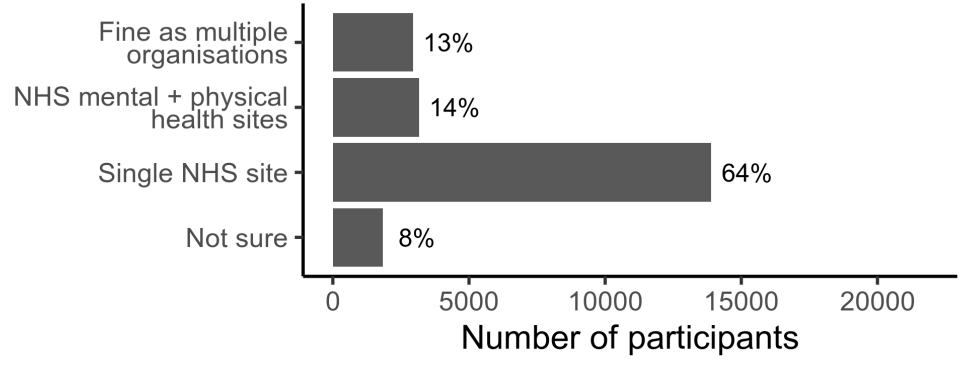

\section{F. Specimen consent form}

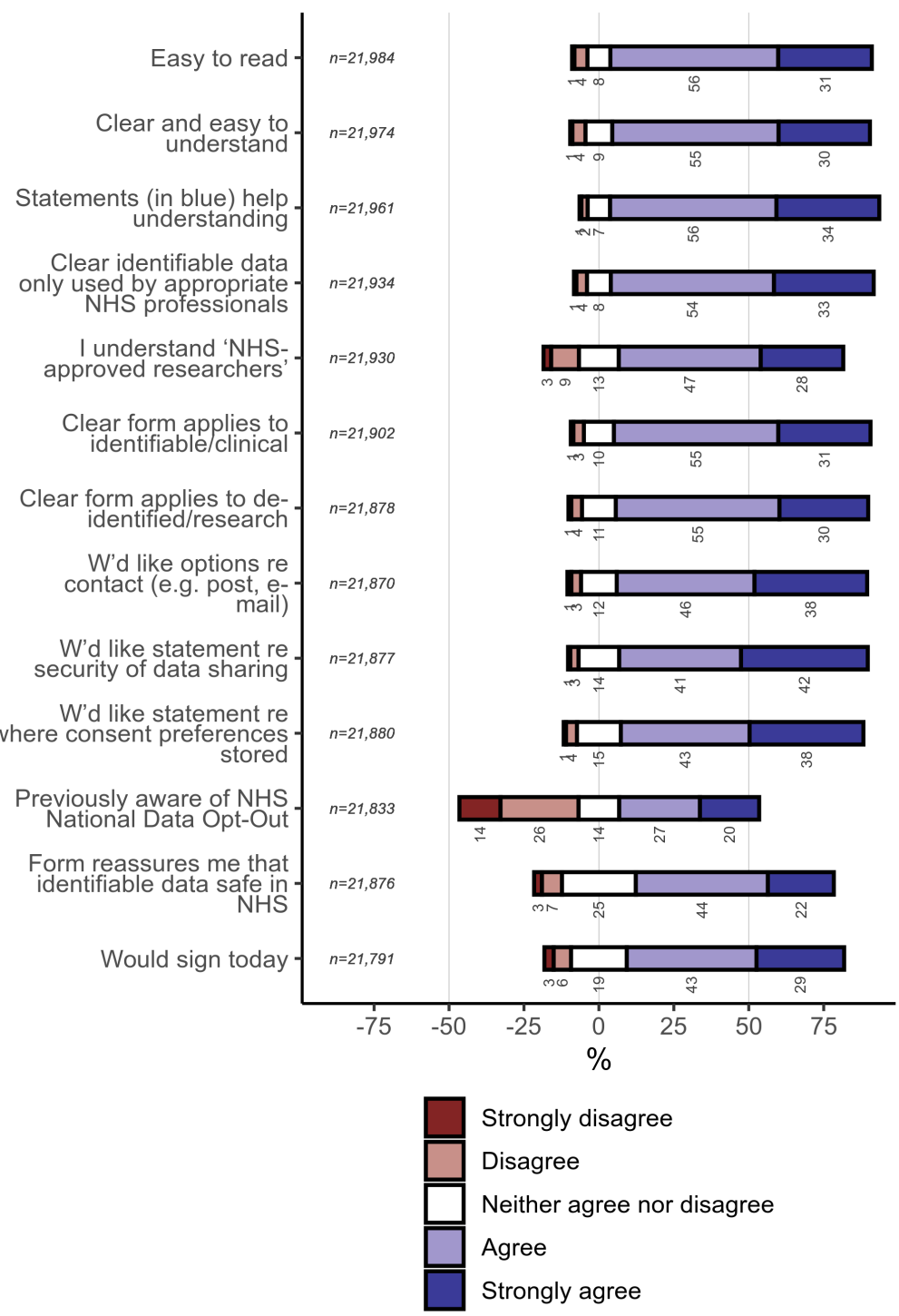


medRxiv preprint doi: https://doi.org/10.1101/2021.07.19.21260635; this version posted July 19,2021 . The copyright holder for this preprint (which was not certified by peer review) is the author/funder, who has granted medRxiv a license to display the preprint in perpetuity.

It is made available under a CC-BY 4.0 International license .

\section{SUPPLEMENTARY MATERIALS}

\section{Public opinion on sharing data from UK health services for clinical and research purposes without explicit consent (Jones et al.)}

\section{Contents}

S1. Supplementary Methods

S1.1. Survey design

S1.2. Analysis of geography including Index of Multiple Deprivation

S1.3. Sensitivity analysis via survey weighting

S1.4. Effect size plots

S1.5. Free-text values and comments

S2. Supplementary Results

S2.1. Recruitment and completion

S2.2. Demographics

S2.3. Experience

S2.4. Raking

S2.5. Weighted analysis of sharing preferences

S2.6. Weighted views on linkage to non-health data for research

S2.7. Effect sizes

S2.8. Weighted views on a national data sharing consent system

S2.9. Free-text comments on the suggested consent form

S2.10. Other free-text comments

S3. Supplementary References

S4. Supplementary Tables

S5. List of appendices

S6. Supplementary Figure Legends

S7. Supplementary Figures

Appendix A: Underlying REDCap survey design

Appendix B: Survey

Appendix C: STROBE statement for cross-sectional studies 
medRxiv preprint doi: https://doi.org/10.1101/2021.07.19.21260635; this version posted July 19, 2021. The copyright holder for this preprint (which was not certified by peer review) is the author/funder, who has granted medRxiv a license to display the preprint in perpetuity.

It is made available under a CC-BY 4.0 International license.

\section{S1. Supplementary Methods}

\section{S1.1. Survey design}

The survey sequence is shown in full in the Appendices. In outline, it was as follows:

- Information, consent, and a question how the participant heard about the survey. (Participants were asked to indicate the health organization, if any, through which they had heard about the study and recruitment was attributed to those sites.)

- An explanation of "NHS" (used as shorthand for NHS/HSC), "health data", "identifiable health data", and "clinical care".

- Questions about current and desired sharing of identifiable health data for clinical care purposes.

- A multiple-choice question on the respondent's understanding of how NHS clinical care providers currently share their identifiable data for clinical care purposes, without asking each time.

- A statement that most NHS providers are separate and do not currently share identifiable data without asking, followed by a multiple-choice question as to if/how the NHS should share the respondent's identifiable data for clinical care purposes, without asking each time (with all stems ending “... without asking me first").

- Questions about personal experience of health conditions.

- Whether the respondent had or hadn't experienced a mental health $(\mathrm{MH})$ condition at some point (or a prefer-not-to-say option). If answered positively, categorical questions about what sort of condition that was, and whether it was recent or $>5$ years ago, and what sort of support had been obtained (e.g. from NHS or other sources).

- Whether the respondent had ever used physical health services, and if so, which categories.

- Fictional examples of identifiable health data were presented. These included identifiers, diagnoses, and notes.

- A framing statement was presented, randomized to be one of the following:

- Neutral: "We would like to find out your perspective on using information about your mental health and your physical health."

- MH concern: "Previous surveys have found that people have more concerns about the use of their identifiable health data relating to their mental health than other aspects of their physical health care." This statement was based on previous findings. ${ }^{1}$

- Holistic: "Mental and physical illnesses overlap, so holistic health care is important. Mental health problems have physical consequences, and physical illnesses have important consequences for mental health." This statement is also true (e.g. ${ }^{2,3}$ ).

- Likert-style questions about how likely the respondent would be to share their identifiable physical health data, for clinical care purposes, with a range of NHS "destinations", without being asked each time.

- Likert-style questions about how likely the respondent would be to share their identifiable mental health data, for clinical care purposes, with a range of NHS destinations, without being asked each time.

- Fictional examples of de-identified structured health data were presented (the same examples as before, now de-identified, and without any free text). These included alphanumeric research identifiers, "blurred" demographics (age, sex, geographical region), and diagnoses.

- Likert-style questions about how likely the respondent would be to share their de-identified (structured) physical health data with a range of research destinations, without giving consent each time.

- $\quad$ Likert-style questions about how likely the respondent would be to share their de-identified (structured) mental health data with a range of research destinations, without giving consent each time.

- Fictional examples of de-identified free-text health data were presented. These were the same de-identified data as before, but now with de-identified versions of the free-text notes. Explicit commentary was given that there was more information present, and a slightly higher risk of inadvertent identification. We gave the example of a hypothetical newspaper report that might enable someone to re-identify a patient.

- $\quad$ Likert-style questions about how likely the respondent would be to share their de-identified (free text) physical health data with a range of research destinations, without giving consent each time.

- $\quad$ Likert-style questions about how likely the respondent would be to share their de-identified (free text) mental health data with a range of research destinations, without giving consent each time. 
medRxiv preprint doi: https://doi.org/10.1101/2021.07.19.21260635; this version posted July 19, 2021. The copyright holder for this preprint (which was not certified by peer review) is the author/funder, who has granted medRxiv a license to display the preprint in perpetuity.

It is made available under a CC-BY 4.0 International license.

- An explicit change of topic was noted.

- We asked Likert-style questions about how likely people would be to sign up to a single system for controlling how one's NHS data is used (clinically and for research), for a variety of types of system (e.g. online, in person), who should look after such consent-related data, what the respondent's preferred method would for changing their preferences, and overall how likely they would be to sign up to such a system.

- We showed a specimen consent form for such a system (see below for full details).

- First, the specimen form asked about sharing data for direct health care purposes.

- It defined "confidential patient information" ${ }^{4}$, and set the context in terms of health care being provided directly to the respondent.

- It offered a yes/no decision: "I agree that all NHS care providers and professionals may share my confidential patient information with each other for the purposes of my treatment and care."

- Second, the specimen form asked about the use of de-identified data for research.

- It provided brief information about the NHS's promises to use anonymised data for research (e.g. $\left.{ }^{5,6}\right)$. It said that research was conducted by the NHS and by NHS-approved researchers such as universities. It referred to strict security controls and NHS oversight.

- It offered a yes/no decision: "I agree that all NHS care providers may share my confidential patient information with each other and de-identify it for the purpose of research."

- We phrased the question in this way because it is already permitted, given NHS research ethics approvals, for NHS bodies to de-identify health data for research. ${ }^{7,8}$ However, cross-site linkage within the NHS is more challenging; if linkage is conducted with direct identifiers such as NHS numbers, this is work involving confidential patient information for research, which requires either explicit consent or approvals (in England) under section 251 of the NHS Act $2006{ }^{4}$ (as amended) and the Health Service (Control of Patient Information) Regulations 2002. ${ }^{9}$ That is the case even if the data are de-identified subsequently and researchers never see identifiable information.

- We said also that saying no would not prevent all uses of one's confidential information for research. At present, in England, the NHS National Data Opt-Out is the mechanism to opt out from uses of one's confidential personal information where that use is governed by section 251 of the NHS Act. ${ }^{10,11}$

- Third, the specimen form asked about taking part in research.

- It discussed briefly research involving direct participation, stating that the NHS promised to inform people of research studies for which they may be eligible, ${ }^{5,6}$ and saying that there is never a commitment to take part.

- It offered a yes/no decision: "I agree that NHS-approved researchers may learn my identity and contact me directly about research studies for which I may be eligible."

- Having showed the respondent the specimen consent form, we asked Likert-style questions about its clarity, how the respondent understood its meaning, whether some additional aspects should be added, whether the respondent was previously aware of the NHS National Data Opt-Out, and whether the respondent would choose to sign such a form if it were available to them today.

- We asked, via a multiple-choice question, whether sign-up portals for research should be multiple (as they are now), single (across the NHS), or split by mental/physical health research.

- We asked about the respondents' preference for linkage of their health data to other data sources for research. We set out a basic method commonly used for identifiable linkage, in which special permissions are sought, trusted third-party linkage is conducted (using identifiable information), followed by de-identification for research. We asked whether the respondent would be happy (yes / not sure / no / prefer not to say) for their health data to be linked to a number of "state" sources (education, police/criminal justice, transport, housing, immigration, social security), giving simple examples of the potential research reasons for each linkage, plus universities (e.g. if the respondent had volunteered for research studies) and data held by private companies.

- Finally, we asked optional demographic questions: gender; age range; ethnicity; sexuality; religion; employment status, with conditional questions sufficient to determine the UK Office for National Statistics (ONS) National Statistics Socio-Economic Classification (NS-SEC) ${ }^{12}$ via the "self-coded" method ${ }^{13}$ if the respondent answered in full; UK nation of residence; and (if the respondent was willing) their postcode, to calculate a "blurred" geographical version as described below. We used ONS demographic categories where available. We offered the option to leave an e-mail address to receive a summary of results when available.

- The survey closed by thanking the participant (not shown in the Appendices).

The REDCap design for the survey is shown in Appendix A, and the resulting survey (including the specimen consent form) is shown in Appendix B. 
medRxiv preprint doi: https://doi.org/10.1101/2021.07.19.21260635; this version posted July 19, 2021. The copyright holder for this preprint (which was not certified by peer review) is the author/funder, who has granted medRxiv a license to display the preprint in perpetuity.

It is made available under a CC-BY 4.0 International license.

\section{S1.2. Analysis of geography including Index of Multiple Deprivation}

Where participants agreed to leave a postcode, this was converted to a larger ONS geographical area, so that individuals could not inadvertently be identified. In turn, the larger geographical area was converted to an Index of Multiple Deprivation (IMD), a composite rank measure covering income, employment, education, health, crime, barriers to housing and services, and living environment. ${ }^{14}$ A lower raw IMD indicates greater deprivation. For England and Wales, postcodes were converted to a Lower Layer Super Output Area; these have a minimum population of 1,000 and a mean population of 1,500. ${ }^{15}$ For Scotland, the Data Zone was used; for Northern Ireland (NI), the Super Output Area (SOA). Here, we use the term "geographical area" (GA) for LSOA (England and Wales), DZ (Scotland), or SOA (NI). We used GAs from the 2011 Census.

GAs were converted to a UK-wide IMD score, ${ }^{16,17}$ using the scale relative to England, in which high numbers represent greater deprivation. As this UK-wide data set uses $2001 \mathrm{DZs}$ for Scotland, we mapped these to $2011 \mathrm{DZs} .{ }^{18} \mathrm{Where}$ multiple 2001 DZs mapped to one 2011 DZ, we took the mean of their UK-wide IMD scores, weighted by their population contribution to the $2011 \mathrm{DZ} .^{18}$

Since GAs do not have equal populations, we corrected for population when calculating centile of deprivation. We used mid-2019 ONS estimates of GA population. ${ }^{19-21}$ We calculated deprivation centile (100\% meaning most deprived) by calculating, for each GA, "what percentage of the total UK population $(66,796,806)$ live in a GA with a UK IMD score that is equal to or lower than that of this GA (i.e. in areas that are equally or less deprived than this GA)?". We calculated quartiles similarly.

To show the distribution of deprivation, we plotted the distribution of deprivation centile using a Gaussian kernel density estimate.

For map representations, the Apr 2019 ONS local authority district boundaries ${ }^{22}$ (which exclude the Channel Islands) were used with the Nov 2019 ONS Postcode Directory. ${ }^{23}$

\section{S1.3. Sensitivity analysis via survey weighting}

As a sensitivity analysis to correct for unrepresentative demographic sampling during general linear modelling, we used raking, ${ }^{24}$ specifically the American National Election Study (ANES) weighting algorithm ${ }^{25}$ via the anesrake package. ${ }^{26,27}$ We defined dimensions (classification variables) and categories (within dimensions) as shown in Supplementary Table 1, collapsing across some low-frequency categories in the survey. We included all such variables in the raking, and used the default weight cap of 5 .

The algorithm does not alter weights for categories for which population expected proportions are not known (e.g. those identifying as neither male nor female, for which Census data are not available, or those answering "prefer not to say" for a given question). Such respondents are therefore assigned a weight of 1 in that category, representing them fairly in the absence of any other information with which to weight them.

Population values for some questions were not available; for example, sexual orientation was not part of the UK 2011 Census. $^{28}$

We weighted all respondents once only, consistently (ignoring the potential for discrepant drop-out rates across the survey).

We used weighted versions of the statistical models (see Methods) that did not include demographic predictors, labelling these with "W" (e.g. model CW1 was a weighted version of model C1).

\section{S1.4. Effect size plots}

We show effect sizes with $95 \%$ confidence intervals from selected statistical models. We use the conventional language of "factor" (discrete predictor), "levels" (possible values of a factor), and "term" (individual predictive term in a GLM, such as "destination" or "destination $\times$ nature"). Effect sizes are shown as uncorrected pairwise comparison to a reference category within each term. For age, we used the central category (age range 45-54) as the reference category, because there were very few participants in the "under 18" category. For brevity, we restrict plots to those model terms with a significant $F$ test. We show degrees of freedom to 1 decimal place and statistics to 3 significant figures.

$F$ tests, as for the main results, were taken from anova(model) via lmerTest::anova.lmerModLmerTest, giving type III sums of squares via the Satterthwaite method for degrees of freedom. ${ }^{29}$ Type III sums of squares test the effect of each term "over and above" others. ${ }^{30}$ Pairwise comparisons were taken from summary(model) via lmerTest::summary.lmerModLmerTest, also using Satterthwaite's method.

We note the important difference between these pairwise contrasts, helpful for basic visual display, and the omnibus $F$ test for the term. ${ }^{30}$ In particular, we note firstly that for a single factor with three levels $(\mathrm{A}, \mathrm{B}$, and $\mathrm{C}$ with $\mathrm{A}$ as the reference level), the omnibus $F$ test tests the null hypothesis $\mathrm{A}=\mathrm{B}=\mathrm{C}$; if this null hypothesis is rejected, it remains possible that neither the pairwise hypothesis $\mathrm{A}=\mathrm{B}$ nor the hypothesis $\mathrm{A}=\mathrm{C}$ is rejected (for example, if the ordering is 
medRxiv preprint doi: https://doi.org/10.1101/2021.07.19.21260635; this version posted July 19, 2021. The copyright holder for this preprint (which was not certified by peer review) is the author/funder, who has granted medRxiv a license to display the preprint in perpetuity.

It is made available under a CC-BY 4.0 International license .

$\mathrm{B}<\mathrm{A}<\mathrm{C}$ ). Thus, failure to observe differences in the specific pairwise contrasts does not imply that there are no differences in the data. Secondly, a similar effect can be observed with interactions: pairwise contrasts within interaction components may sometimes be suboptimal compared to subgroup simple effects analyses. ${ }^{30}$ Thus, we used simple effects analysis for detailed follow-up of significant interactions where appropriate.

\section{S1.5. $\quad$ Free-text values and comments}

Some respondents wrote in responses for "other" categories. Some provided free-text comments where invited to do so. A few e-mailed the study team separately. We provide narrative summaries of these answers, paraphrasing to avoid direct quotations and reporting " $n<10$ " where appropriate to mask small numbers.

For free-text comments on the proposed draft national consent form, we conducted a thematic analysis and report tallies by theme.

\section{S2. Supplementary Results}

\section{S2.1. Recruitment and completion}

Supplementary Figure 1 shows recruitment sources, recruitment rates, and survey participation by stage.

\section{S2.2. Demographics}

A demographic breakdown is shown in Supplementary Figure 2.

Free-text values provided in response to "other, please specify" categories included:

- Mental health conditions $(n=274)$ : many unique responses, with non-unique responses distinct from the options offered including: ADHD [attention-deficit/hyperactivity disorder], Asperger's syndrome/autism/autistic spectrum disorder, bereavement, body dysmorphic disorder, dissociative disorders, gambling disorders, insomnia, low mood, memory problems, menopause-associated symptoms, non-epileptic attack disorder, overdose, post-traumatic stress disorder, postnatal depression, suicidality, and stress.

- Mental health services used $(n=254)$ : many unique responses, with non-unique responses including: counselling services, military services, specific named charities (including Mind and Samaritans), university mental health support services, and well-being services.

- $\quad$ Physical health services used $(n=258)$ : many unique responses, with non-unique responses including: chiropractors, complementary therapists, dentistry, maternity services, NHS web sites, osteopaths, pharmacists, physiotherapists, and well-being services.

- $\operatorname{Gender~}(n=29)$ : non-unique responses included: agender, gender fluid, non-binary, trans/transgender.

- Ethnicity $(n=150)$ : a large number of responses more detailed than the ONS options on offer, with some critical of the premise.

- Sexuality $(n=65)$ : a number of unique options and some critical of the premise or phrasing, plus some with multiple responses (e.g. asexual, panromantic, pansexual).

- Religion $(n=219)$ : a range, some more closely specifying options offered (e.g. agnostic, atheist, Baptist, Catholic, Church of England, humanist, Jehovah's Witness, Methodist, Orthodox, Quaker) and some for beliefs not listed (e.g. Baha'i, druid, Jedi, pagan, pantheist, spiritualist, Wiccan), including a number of unique responses.

- Geography (England $n=43$, Scotland $n<10$, Wales $n=20$, Northern Ireland $n<10$ ): a range of geographical divisions not matching the categories offered.

\section{S2.3. Experience}

Participants' experience of mental health conditions/service and physical health services are shown in Supplementary Figure 3.

\section{S2.4. Raking}

The raking algorithm converged stably, and substantially improved the match to population marginal proportions, though was unable to make the resulting weights match the population marginals completely within the constraints specified. We show observed and raked proportions in Supplementary Table 1. 
medRxiv preprint doi: https://doi.org/10.1101/2021.07.19.21260635; this version posted July 19, 2021. The copyright holder for this preprint (which was not certified by peer review) is the author/funder, who has granted medRxiv a license to display the preprint in perpetuity.

It is made available under a CC-BY 4.0 International license .

\section{S2.5. Weighted analysis of sharing preferences}

Weighted analyses (Supplementary Figure 4) were quantitatively similar to the primary results (compare Figure 3), and statistical analyses showed the same key patterns, although with somewhat weaker framing effects.

For clinical purposes (model CW1, $n=24497)$, there were effects including destination $\left(F_{3,181628}=6310\right.$, VLP), nature $\left(F_{1,181756}=4860, \mathrm{VLP}\right)$, nature $\times$ framing $\left(F_{2,181756}=21 \cdot 3, p=5 \cdot 41 \times 10^{-10}\right)$, destination $\times$ nature $\left(F_{3,181624}=5 \cdot 84, p=\right.$ $0 \cdot 000557)$, and destination $\times$ framing $\left(F_{6,181628}=4 \cdot 38, p=0.000199\right)$. In sub-analyses of the framing effects (analysis of $\mathrm{MH}$ and PH data separately using model CW1B), there was no effect of framing for PH data $(F<1$, NS) but this time the framing effect for $\mathrm{MH}$ data was not itself significant (framing, $F_{2,13607}=1 \cdot 74$, NS; destination $\times$ framing, $F_{6,84700}=$ $1.91, p=0.0748$ ). As for the main analysis (model C1), the framing effects were slightly smaller for geographically broader (e.g. UK-wide) sharing, driving a destination $\times$ framing interaction via $\mathrm{PH}$ data.

For research purposes (model RW1, $n=23869$ ), main effects included destination $\left(F_{5,547684}=74700\right.$, VLP) nature $\left(F_{1,547914}=1613, \mathrm{VLP}\right)$, detail $\left(F_{1,548574}=5270, \mathrm{VLP}\right)$, and framing $\left(F_{2,13472}=3 \cdot 09, p=0 \cdot 045\right)$. Interactions included destination $\times$ nature $\times$ detail $\left(F_{5,547655}=8 \cdot 64, p=8 \cdot 64 \times 10^{-8}\right)$ and nature $\times$ framing $\times$ pandemic $\left(F_{2,547914}=5 \cdot 25, p=\right.$ 0.00536). In sub-analyses of the framing effects (analysis of MH and PH data separately using model RW1B), framing main effects were not independently significant, though there were destination $\times$ framing interactions as before.

\section{S2.6. $\quad$ Weighted views on linkage to non-health data for research}

Supplementary Figure 5 shows weighted views on linkage to non-health data for research (compare Figure 4).

\section{S2.7. Effect sizes}

Supplementary Figure 6 shows effect sizes for models C1, R1, and L1. These models include data from all participants who answered the relevant questions, including those who did not supply full demographic information (compare Figure 6).

\section{S2.8. Weighted views on a national data sharing consent system}

Supplementary Figure 7 shows weighted views on a national data consent system (compare Figure 7).

\section{S2.9. Free-text comments on the suggested consent form}

Themes of free-text comments in relation to the proposed consent form $(n=3112)$ included:

- Form design:

- Too long/complex $(n=732)$. The form was too long and/or complex, or the text (or aspects of the text) should be clearer or simpler, including statements that the reader found it OK but felt that others (not specified in detail) would not.

- Visual style $(n=395)$. Regarding visual clarity and style (e.g. typography, layout, colours, and the spelling of 'organization' versus 'organisation'). ${ }^{31}$

- Clear $/$ good $(n=159)$. The form was satisfactory, good, clear, and/or concise.

- Extra information or accessible versions $(n=271)$. There should be accessible forms, easy-read versions, alternative language versions, or accompanying explanations (e.g. leaflet, illustrations, video, explanations of the benefits and risks of data sharing).

- Too brief $(n=18)$. It was too brief, and/or required more detail or explanation (in general).

- Biased $(n=16)$. It was biased, coercive, or misleading in its questions.

- Method of completion:

- Digital $(n=69)$. A digital or online version would be desirable or preferable (or in some cases that a paper copy would be desirable or necessary as well).

- Non-digital $(n=26)$. A paper copy would be desirable or necessary, or that not everyone could use internet-based methods.

- One-to-one support $(n=90)$. One-to-one support (e.g. face-to-face, e-mail, telephone) would be desirable or necessary (from a clinician or other unbiased person, including support for those who may lack capacity to decide, and for children).

- Copies $(n=27)$. People should have copies of what they agreed to. 
- Changing preferences $(n=96)$. It should be easy to revisit and update one's preferences and/or contact details (and/or clarity on what would happen to data previously shared under such circumstances).

- Enough time $(n=49)$. It is important people have time to complete the form and do not feel pressured to do so, and/or are not asked during times of personal medical crisis.

- Legal aspects:

- Legal $(n=58)$. That the Data Protection Act and/or European Union (EU) General Data Protection Regulation (GDPR), Access to Health Records Act, Information Commissioner's Office, NHS privacy documents (e.g. privacy impact assessments, Caldicott Guardian framework), or mental capacity frameworks (e.g. Mental Capacity Act, Lasting Power of Attorney) should be referenced explicitly, or views that the proposed system/form would be (or that existing NHS information systems are) incompatible with one of these.

- Managing data related to consent:

- Data for the consent process $(n=83)$. Relating to self-identification when completing the form: that asking for an NHS number is problematic as people may not know this, that some identifiers (e.g. full name, address, e-mail address) are unnecessary or sometimes unnecessary, or that some (e.g. telephone number, previous names and addresses) should be added, or concerns about the management of identity information used for the consent form.

- Management of healthcare data:

- De-identification $(n=164)$. That aspects of de-identification/anonymisation/pseudonymisation needed to be clearer, including that asking for identity data whilst recording preferences about de-identified data use was confusing, or that any form of pseudonymisation (rather than full anonymisation) is undesirable, or that examples should be given of identifiable versus de-identified data.

- Data security $(n=594)$. That the security and privacy of healthcare data is of paramount importance, including that more detail should be provided about data security/sharing or privacy controls, or that the respondent did not trust the NHS or the UK to manage data security properly.

- Centralization $(n=30)$. Greater centralisation of data increases concern and risks.

- Sharing desirable $(n=290)$. Data sharing is desirable in general, for clinical or research purposes or not specified.

- Sharing undesirable $(n=74)$. Data sharing is undesirable in general, e.g. without case-by-case specific consent ( \pm except in emergencies).

- Opt-outs $(n=134)$. That opt-outs should be more prominent, the default, that the system should be linked with the NHS National Data Opt-Out (directly or by implication), or that the relationship to NHS Act Section 251 approval was unclear.

- Categories of healthcare data:

- Distinguish mental/physical health $(n=45)$. Mental health and physical health data should be distinguished.

- Combine mental/physical health $(n<10)$. Mental health and physical health data should not be distinguished.

- Distinguish health data in other ways $(n=11)$. Further subtypes of health data (e.g. sexual health, drug/alcohol use) should be distinguished.

- Distinguish free text from structured data $(n=23)$. Free/narrative text should be distinguished from structured data.

- Distinguish data by age $(n<10)$. Data should be distinguished by its age (historical versus recent).

- Categories of use:

- Clinical versus research $(n=44)$. Clinical and research uses of data should be more clearly distinguished (e.g. not included on the same form).

- Transparency of use $(n=34)$. That people should be informed about, or be able to inspect, or choose regarding, each individual use of their data, and/or the results of research involving their data.

- Profit-making $(n=198)$. That profit-making use should not happen, or people should be paid directly for providing data used for profit, or that the NHS should ensure that it profits from such data use.

- Data or use/users, not distinguished:

- More detail $(n=74)$. More detailed options should be available (in general).

- $\quad$ End users: 
medRxiv preprint doi: https://doi.org/10.1101/2021.07.19.21260635; this version posted July 19, 2021. The copyright holder for this preprint (which was not certified by peer review) is the author/funder, who has granted medRxiv a license to display the preprint in perpetuity.

It is made available under a CC-BY 4.0 International license .

- Specify clinical users more $(n=147)$. Permissions to share clinical data should not relate to the whole NHS, but be more detailed (e.g. local, regional, or regarding specific staff groups, or regarding private healthcare providers, or the relationship to social rather than health care).

- Consent not needed $(n<10)$. That consent (or at least explicit consent) is not required for aspects of data sharing, or should not be required.

- Specify researchers more $(n=268)$. That "NHS-approved researchers" is too vague, and that more detail about who such researchers are, or more detailed options to select from (up to and including case-by-case approval by the patient concerned), should be provided.

- Third-party/private users $(n=417)$. That healthcare data should not be available to private or third-party companies (or should require specific permission), including insurance companies and other profit-making organizations, or that later developments to provide them with data would be of concern.

- Other state users $(n=29)$. That use by other state/Government organizations would be of concern, or more detail would be required in that regard.

- Overseas users $(n=52)$. That use by overseas users (e.g. researchers) would be of concern, e.g. because other countries have different data regulations.

- Contact by researchers:

- Contact by researchers $(n=69)$. That more detailed options should be available about consent for research, or that being contact directly would be of concern (including about frequency of contact, and preferences that contact is always via clinical teams rather than researchers being given identifiable information).

- Overall objectives:

- Good idea $(n=128)$. The consent system or project was a good idea (in general).

- Bad idea $(n=16)$. The consent system or project was a bad idea, or unnecessary.

- Other:

- We did not tally comments relating to other aspects, such as the accuracy of health records themselves, patient access to health records (or holding the primary version of all their health data themselves), descriptions of an individual's care, details of how the respondent would themselves choose, comments on the relationship to consent for clinical treatment, expressed wishes that the research team be shot, comments that people never read forms anyway, views that an independent body should oversee such a process, or concerns about research bias relating to who would or would not consent to their data being used.

\section{S2.10. Other free-text comments}

Themes of the free-text comments sent to the research team separately included:

- That the respondent's preferences regarding mental versus physical health data had been driven by personal experience of information being misused $(n<10)$.

- That all research use of data should require informed consent, involving participants' knowledge of the nature of the research $(n<10)$. 
medRxiv preprint doi: https://doi.org/10.1101/2021.07.19.21260635; this version posted July 19, 2021. The copyright holder for this preprint (which was not certified by peer review) is the author/funder, who has granted medRxiv a license to display the preprint in perpetuity.

It is made available under a CC-BY 4.0 International license.

\section{S3. Supplementary References}

1 Aitken M, de St Jorre J, Pagliari C, Jepson R, Cunningham-Burley S. Public responses to the sharing and linkage of health data for research purposes: a systematic review and thematic synthesis of qualitative studies. BMC Med Ethics 2016; 17: 73.

2 Grippo AJ, Johnson AK. Biological mechanisms in the relationship between depression and heart disease. Neurosci Biobehav Rev 2002; 26: 941-62.

3 Royal College of Psychiatrists. CR183: Liaison psychiatry for every acute hospital. Integrated mental and physical healthcare. 2013. https://www.rcpsych.ac.uk/docs/default-source/members/faculties/liaison-psychiatry/ cr183liaisonpsych-every-acute-hospital.pdf?sfvrsn=26c57d4_2.

4 UK. National Health Service Act 2006. 2006 https://www.legislation.gov.uk/ukpga/2006/41.

5 NHS England. The NHS Constitution for England. 2013; published online March 26. https://www.gov.uk/government/publications/the-nhs-constitution-for-england.

6 NHS England. The NHS Constitution for England. 2015; published online July 27. https:/www.gov.uk/government/publications/the-nhs-constitution-for-england.

7 UK. Data Protection Act 2018. 2018 http://www.legislation.gov.uk/ukpga/2018/12/contents/enacted.

8 European Parliament and Council. Regulation (EU) 2016/679 (General Data Protection Regulation). Off J Eur Union 2016; L119: 1-88.

9 UK. The Health Service (Control of Patient Information) Regulations 2002. 2002 http://www.legislation.gov.uk/uksi/2002/1438/contents/made.

10 NHS. National Data Opt-out: Factsheet 2 - When it applies. 2018. https:/digital.nhs.uk/binaries/content/assets/website-assets/services/national-data-opt-out-programme/guidance-forhealth-and-care-staff/nhs-factsheet-2-23052018.pdf (accessed July 26, 2019).

11 NHS Digital. Understanding the national data opt-out. 2019. https://web.archive.org/web/20200804083843/https://digital.nhs.uk/services/national-data-opt-out/understandingthe-national-data-opt-out.

12 Office for National Statistics. Standard Occupational Classification 2010: Volume 3: The National Statistics Socioeconomic Classification: (Rebased on the SOC2010) User Manual. 2010.

https:/www.ons.gov.uk/file?uri=/methodology/classificationsandstandards/standardoccupationalclassificationsoc/ soc2010/soc2010volume3thenationalstatisticssocioeconomicclassificationnssecrebasedonsoc2010/ soc2010vol31amendedjanuary2013tcm77179133.pdf (accessed Feb 13, 2020).

13 Office for National Statistics. Deriving the NS-SEC: self-coded method. 2012. https://www.ons.gov.uk/methodology/classificationsandstandards/standardoccupationalclassificationsoc/soc2010/ soc2010volume3thenationalstatisticssocioeconomicclassificationnssecrebasedonsoc2010\#deriving-the-ns-sec-selfcoded-method (accessed Aug 23, 2019).

14 UK Ministry of Housing, Communities \& Local Government. English indices of deprivation 2015. 2015. https:/www.gov.uk/government/statistics/english-indices-of-deprivation-2015 (accessed May 15, 2018).

15 UK Office for National Statistics. Census geography: An overview of the various geographies used in the production of statistics collected via the UK census. 2011.

https://www.ons.gov.uk/methodology/geography/ukgeographies/censusgeography (accessed May 15, 2018).

16 Abel GA, Barclay ME, Payne RA. Adjusted indices of multiple deprivation to enable comparisons within and between constituent countries of the UK including an illustration using mortality rates. BMJ Open 2016; 6: e012750. 
medRxiv preprint doi: https://doi.org/10.1101/2021.07.19.21260635; this version posted July 19, 2021. The copyright holder for this preprint (which was not certified by peer review) is the author/funder, who has granted medRxiv a license to display the preprint in perpetuity.

It is made available under a CC-BY 4.0 International license .

17 Abel GA, Payne RA, Barclay ME. UK Deprivation Indices. 2016; published online Nov 21. https://dx.doi.org/10.5523/bris.1ef3q32gybk001v77c1ifmty7x (accessed Feb 23, 2020).

18 Scottish Government. Data Zone Matching File (Area and Pop. based 2001 - 2011). 2015. https://www2.gov.scot/Resource/0048/00483037.xlsx.

19 Office for National Statistics. Lower layer Super Output Area population estimates (supporting information). 2019. https://www.ons.gov.uk/peoplepopulationandcommunity/populationandmigration/populationestimates/datasets/ lowersuperoutputareamidyearpopulationestimates.

20 National Records of Scotland. Mid-2019 Small Area Population Estimates for 2011 Data Zones. 2020. https://www.nrscotland.gov.uk/statistics-and-data/statistics/statistics-by-theme/population/population-estimates/ 2011-based-special-area-population-estimates/small-area-population-estimates/mid-2019.

21 Northern Ireland Statistics and Research Agency. 2019 Mid Year Population Estimates for Northern Ireland. 2020. https://www.nisra.gov.uk/publications/2019-mid-year-population-estimates-northern-ireland.

22 Office for National Statistics. Local Authority Districts (April 2019) UK BFE. 2019. https://geoportal.statistics.gov.uk/datasets/b06ce126e1014409ac24c82739b2c130_0.

23 Office for National Statistics. ONS Postcode Directory (November 2019). 2019. https://geoportal.statistics.gov.uk/datasets/ons-postcode-directory-november-2019.

24 Kalton G, Flores-Cervantes I. Weighting methods. J Off Stat 2003; 19: 81-97.

25 DeBell M, Krosnick JA. Computing Weights for American National Election Study Survey Data. Ann Arbor, MI; Palo Alto, CA: American National Election Studies, 2009 https://electionstudies.org/wp-content/uploads/2018/04/nes012427.pdf.

26 Pasek J. ANES weighting algorithm: a description. 2010; published online March 15. https://web.stanford.edu/group/iriss/cgi-bin/anesrake/resources/RakingDescription.pdf.

27 Pasek J. anesrake: ANES Raking Implementation. 2018. https://CRAN.R-project.org/package=anesrake (accessed June 4, 2021).

28 Office for National Statistics. 2011 Census Household Questionnaire. 2011. https://www.ons.gov.uk/file?uri=/census/censustransformationprogramme/consultations/ the2021 censusinitialviewoncontentforenglandandwales/2011censusquestionnaireenglandh1.pdf.

29 Satterthwaite FE. An approximate distribution of estimates of variance components. Biometrics 1946; 2: 110-4.

30 Cardinal RN, Aitken MRF. ANOVA for the Behavioural Sciences Researcher. Mahwah, N.J: L. Erlbaum, 2006.

31 Oxford University Press. New Shorter Oxford English Dictionary. Oxford, UK: Oxford University Press, 1997.

32 Office for National Statistics. Estimates of the population for the UK, England and Wales, Scotland and Northern Ireland: mid-2019. 2020. https://www.ons.gov.uk/peoplepopulationandcommunity/populationandmigration/ populationestimates/datasets/populationestimatesforukenglandandwalesscotlandandnorthernireland.

33 Office for National Statistics. Population estimates for the UK, England and Wales, Scotland and Northern Ireland: mid-2019. 2020; published online June 24.

https://www.ons.gov.uk/peoplepopulationandcommunity/populationandmigration/populationestimates/bulletins/ annualmidyearpopulationestimates/mid2019estimates (accessed Nov 6, 2020).

34 Office for National Statistics. UK population by ethnicity. 2018; published online Aug 1. https://www.ethnicityfacts-figures.service.gov.uk/uk-population-by-ethnicity (accessed Nov 6, 2020).

35 UK Data Service. Age by Highest level of qualification 2011. 2011. http://dx.doi.org/10.5257/census/aggregate2011-2 (accessed Jan 19, 2021). 
medRxiv preprint doi: https://doi.org/10.1101/2021.07.19.21260635; this version posted July 19, 2021. The copyright holder for this preprint (which was not certified by peer review) is the author/funder, who has granted medRxiv a license to display the preprint in perpetuity.

It is made available under a CC-BY 4.0 International license.

36 Office for National Statistics. Population characteristics research tables [2016 estimates]. 2019; published online Dec 4. https://www.ons.gov.uk/peoplepopulationandcommunity/populationandmigration/populationestimates/ datasets/populationcharacteristicsresearchtables (accessed Jan 19, 2021). 
medRxiv preprint doi: https://doi.org/10.1101/2021.07.19.21260635; this version posted July 19,2021 . The copyright holder for this preprint (which was not certified by peer review) is the author/funder, who has granted medRxiv a license to display the preprint in perpetuity.

It is made available under a CC-BY 4.0 International license.

\section{S4. Supplementary Tables}

Supplementary Table 1. Demographic dimensions and categories used for weighting, with UK population marginal proportions $(e)$, observed marginal proportions amongst respondents $(o$, ignoring those who did not answer or answered via a category not acknowledged by UK population statistics), and marginal proportions after raking ( $r$, likewise). Proportions are shown to 3 decimal places; VLP, $p<2 \cdot 2 \times 10^{-16}$

\begin{tabular}{|c|c|c|c|c|c|c|}
\hline $\begin{array}{l}\text { Variable } \\
\text { (dimension) }\end{array}$ & Category & $\begin{array}{l}\text { UK expected } \\
\text { population } \\
\text { proportion, } e\end{array}$ & Reference for $e$ & $\begin{array}{l}\text { Observed } \\
\text { proportion } \\
\text { (ignoring } \\
\text { other/unknown), } o\end{array}$ & $\begin{array}{l}\text { Sample versus } \\
\text { population } \\
\text { proportions }\end{array}$ & $\begin{array}{l}\text { Raked proportion } \\
\text { (ignoring } \\
\text { other/unknown), } r\end{array}$ \\
\hline \multirow[t]{9}{*}{ Age } & Under 18 & $0 \cdot 211$ & 32,33 & $0 \cdot 005$ & $\chi_{8}^{2}=8860, \mathrm{VLP}$ & $0 \cdot 024$ \\
\hline & $18-24$ & $0 \cdot 085$ & & $0 \cdot 050$ & & $0 \cdot 082$ \\
\hline & $25-34$ & $0 \cdot 135$ & & $0 \cdot 139$ & & $0 \cdot 167$ \\
\hline & $35-44$ & $0 \cdot 126$ & & $0 \cdot 163$ & & $0 \cdot 159$ \\
\hline & $45-54$ & $0 \cdot 136$ & & $0 \cdot 218$ & & $0 \cdot 177$ \\
\hline & $55-64$ & $0 \cdot 122$ & & $0 \cdot 228$ & & $0 \cdot 160$ \\
\hline & $65-74$ & $0 \cdot 100$ & & $0 \cdot 150$ & & $0 \cdot 133$ \\
\hline & $75-84$ & $0 \cdot 060$ & & $0 \cdot 043$ & & $0 \cdot 078$ \\
\hline & $85+$ & $0 \cdot 025$ & & $0 \cdot 004$ & & $0 \cdot 019$ \\
\hline \multirow[t]{2}{*}{ Gender } & Female & $0 \cdot 506$ & 32 & $0 \cdot 673$ & $\chi_{1}^{2}=2390, \mathrm{VLP}$ & $0 \cdot 471$ \\
\hline & Male & $0 \cdot 494$ & & $0 \cdot 327$ & & $0 \cdot 529$ \\
\hline \multirow[t]{2}{*}{ Ethnicity } & White & $0 \cdot 860$ & $\begin{array}{l}{ }^{34} \text { (data only available for } \\
\text { England and Wales) }\end{array}$ & $0 \cdot 910$ & $\chi_{1}^{2}=442, \mathrm{VLP}$ & $0 \cdot 861$ \\
\hline & Other & $0 \cdot 140$ & & $0 \cdot 090$ & & $0 \cdot 139$ \\
\hline \multirow[t]{5}{*}{ Education } & No formal & $0 \cdot 232$ & $\begin{array}{l}35 \text {; data for over- } 16 \text { s only; } \\
\text { vocational data absent for } \\
\text { Scotland (ignored in } \\
\text { calculating proportions) }\end{array}$ & $0 \cdot 025$ & $\chi^{2}{ }_{4}=13800, \mathrm{VLP}$ & $0 \cdot 121$ \\
\hline & $\begin{array}{l}\text { Level } 1 \text { and Level } 2 \\
\text { (approximating } \\
\text { "secondary") }\end{array}$ & $0 \cdot 292$ & & $0 \cdot 139$ & & $0 \cdot 250$ \\
\hline & $\begin{array}{l}\text { Level } 3 \text { (approximating } \\
\text { "A-Level/equivalent") }\end{array}$ & $0 \cdot 121$ & & $0 \cdot 122$ & & $0 \cdot 146$ \\
\hline & $\begin{array}{l}\text { Level } 4+ \\
\text { (approximating } \\
\text { undergraduate, } \\
\text { postgraduate, and } \\
\text { professional) }\end{array}$ & $0 \cdot 270$ & & $0 \cdot 589$ & & $0 \cdot 364$ \\
\hline & Vocational & $0 \cdot 084$ & & $0 \cdot 126$ & & $0 \cdot 119$ \\
\hline \multirow[t]{3}{*}{ Religion } & No religion or not stated & $0 \cdot 332$ & $\begin{array}{l}{ }^{36} \text { (Table B; data only } \\
\text { available for England and } \\
\text { Wales) }\end{array}$ & $0 \cdot 618$ & $\chi_{2}^{2}=10900, \mathrm{VLP}$ & $0 \cdot 337$ \\
\hline & Christian & $0 \cdot 565$ & & $0 \cdot 338$ & & $0 \cdot 563$ \\
\hline & Other & $0 \cdot 102$ & & $0 \cdot 043$ & & $0 \cdot 100$ \\
\hline \multirow[t]{4}{*}{ Nation } & England & $0 \cdot 843$ & $\begin{array}{l}32 \text { (Channel Islands not } \\
\text { included) }\end{array}$ & $0 \cdot 994$ & $\chi_{3}^{2}=3660, \mathrm{VLP}$ & $0 \cdot 968$ \\
\hline & Northern Ireland & $0 \cdot 028$ & & $0 \cdot 0002$ & & $0 \cdot 001$ \\
\hline & Scotland & $0 \cdot 082$ & & $0 \cdot 002$ & & $0 \cdot 010$ \\
\hline & Wales & $0 \cdot 047$ & & $0 \cdot 004$ & & $0 \cdot 020$ \\
\hline \multirow{4}{*}{$\begin{array}{l}\text { Index of } \\
\text { multiple } \\
\text { deprivation }\end{array}$} & $\begin{array}{l}\text { First (least deprived) } \\
\text { quartile }\end{array}$ & $0 \cdot 25$ & By definition & $0 \cdot 334$ & $\chi_{3}^{2}=1620, \mathrm{VLP}$ & $0 \cdot 247$ \\
\hline & Second & $0 \cdot 25$ & & $0 \cdot 317$ & & $0 \cdot 195$ \\
\hline & Third & $0 \cdot 25$ & & $0 \cdot 233$ & & $0 \cdot 279$ \\
\hline & Fourth (most deprived) & $0 \cdot 25$ & & $0 \cdot 116$ & & $0 \cdot 279$ \\
\hline
\end{tabular}


medRxiv preprint doi: https://doi.org/10.1101/2021.07.19.21260635; this version posted July 19, 2021. The copyright holder for this preprint (which was not certified by peer review) is the author/funder, who has granted medRxiv a license to display the preprint in perpetuity.

It is made available under a CC-BY 4.0 International license.

\section{S5. List of appendices}

Appendix A shows a screenshot of the full REDCap design for the survey.

Appendix B shows resulting screenshots of the survey running in a web browser. (Questions labelled 11, 12, and 13 internally, as per Appendix A, were the same question, but with differing accompanying framing statements; the "concern" framing is shown here. The last content page is shown twice, once in its starting state and once fully expanded after partial completion with hypothetical data.)

Appendix C is a STROBE statement for cross-sectional studies (page numbers for composite PDF including main manuscript and supplementary materials). 
medRxiv preprint doi: https://doi.org/10.1101/2021.07.19.21260635; this version posted July 19,2021 . The copyright holder for this preprint (which was not certified by peer review) is the author/funder, who has granted medRxiv a license to display the preprint in perpetuity.

It is made available under a CC-BY 4.0 International license.

\section{S6. Supplementary Figure Legends}

Supplementary Figure 1. Recruitment sources, participation over time (shading indicates weekends), and survey completion. The denominator for percentages is the total number of consented participants.

Supplementary Figure 2. Demographics of respondents. The denominator for percentages is the number of people who answered each question. For panels marked $\dagger$, only participants who provided a postcode are included. ONS local authority map and deprivation centiles exclude the Channel Islands. See Supplementary Methods for details of geography and deprivation calculations.

Supplementary Figure 3. Respondents' experience of mental health conditions/services and physical health services. The denominator for percentages is the number of people who answered each question.

Supplementary Figure 4. Opinions about sharing mental and physical health data, weighted according to demographic variables. This is equivalent to Figure 3 apart from the weighting (see Supplementary Methods), with identical conventions. "(W)": weighted.

Supplementary Figure 5. Views on linkage to non-health data for research, weighted according to demographic variables. This is equivalent to Figure 4 apart from the weighting (see Supplementary Methods). "(W)": weighted.

Supplementary Figure 6. Effect sizes for predictors of willingness to (A) share data for clinical purposes (compare Figure 3C), (B) share data for research purposes (compare Figure 3F,H), or (C) support linkage to non-health data for research (compare Figure 4). Analysis via models C1, R1, and L1 respectively. These models include all participants, including those not supplying full demographic details, and therefore do not include the demographic predictors; compare Figure 6. Conventions as for Figure 6.

Supplementary Figure 7. Views on a national data sharing consent system, weighted according to demographic variables. This is equivalent to Figure 7 apart from the weighting (see Supplementary Methods). "(W)": weighted. 
medRxiv preprint doi: https://doi.org/10.1101/2021.07.19.21260635; this version posted July 19, 2021. The copyright holder for this preprint (which was not certified by peer review) is the author/funder, who has granted medRxiv a license to display the preprint in perpetuity.

\section{Supplementary Figure 1}

\section{A. Heard about survey from...}

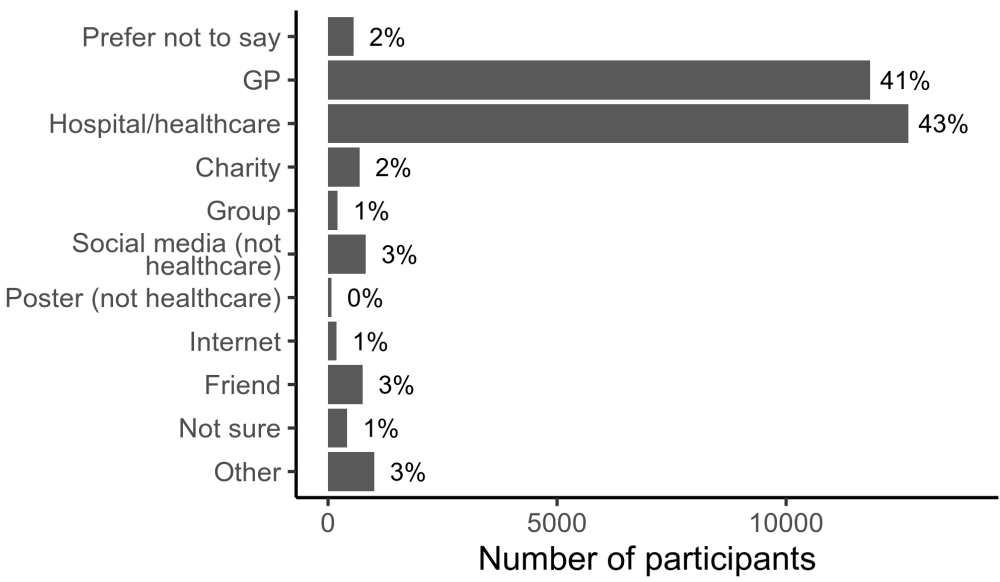

\section{Survey component completion}

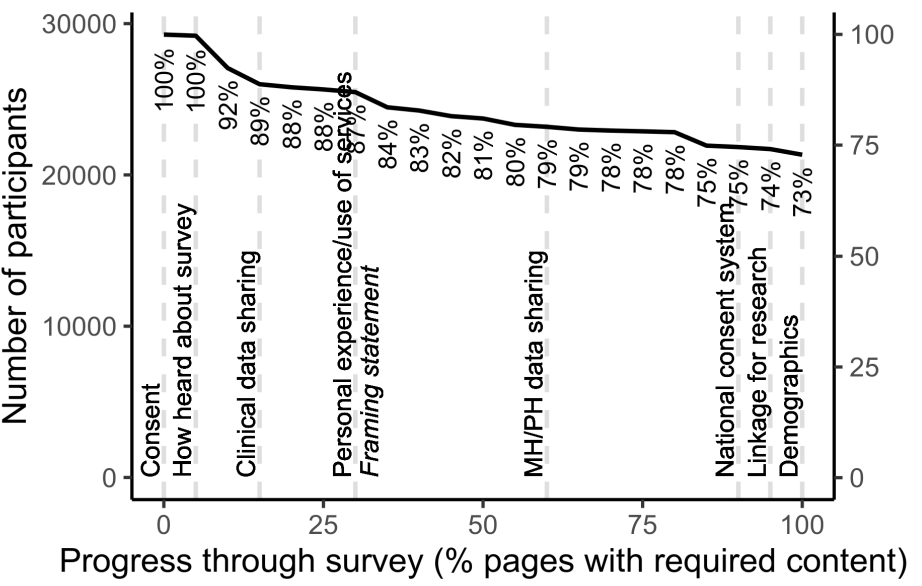

B. Participants per day (and cumulative); total $n=29,275$

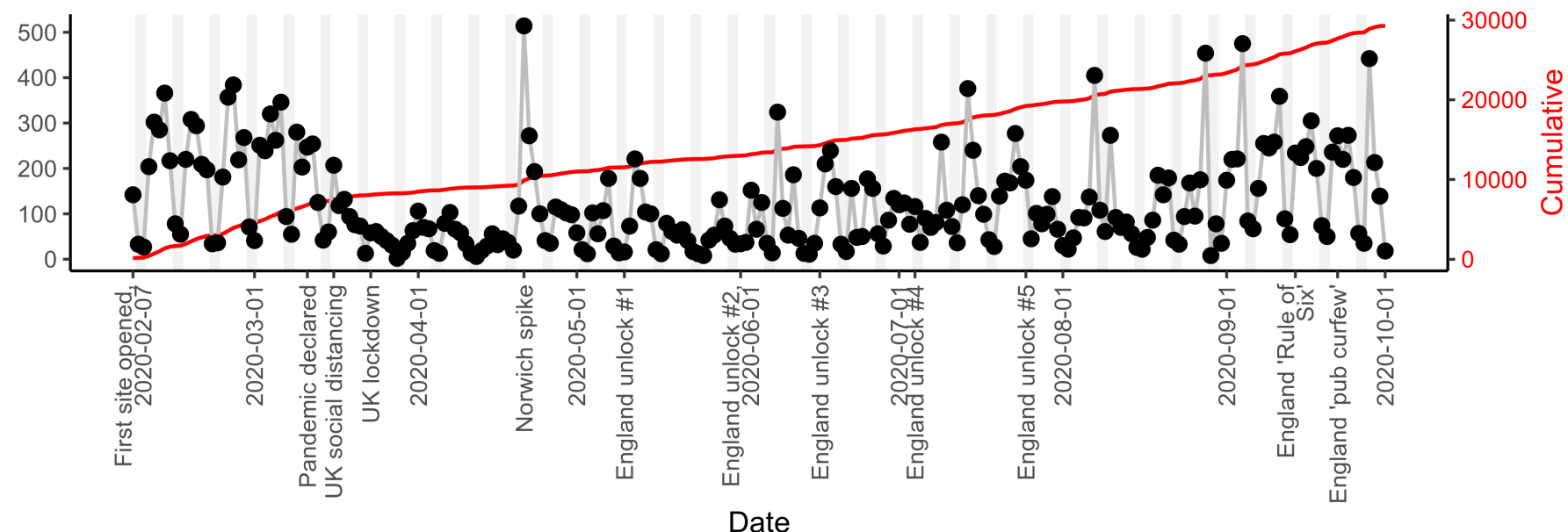


medRxiv preprint doi: https://doi.org/10.1101/2021.07.19.21260635; this version posted July 19, 2021. The copyright holder for this preprint (which was not certified by peer review) is the author/funder, who has granted medRxiv a license to display the preprint in perpetuity.

It is made available under a CC-BY 4.0 International license .

\section{Supplementary Figure 2}

A. Age

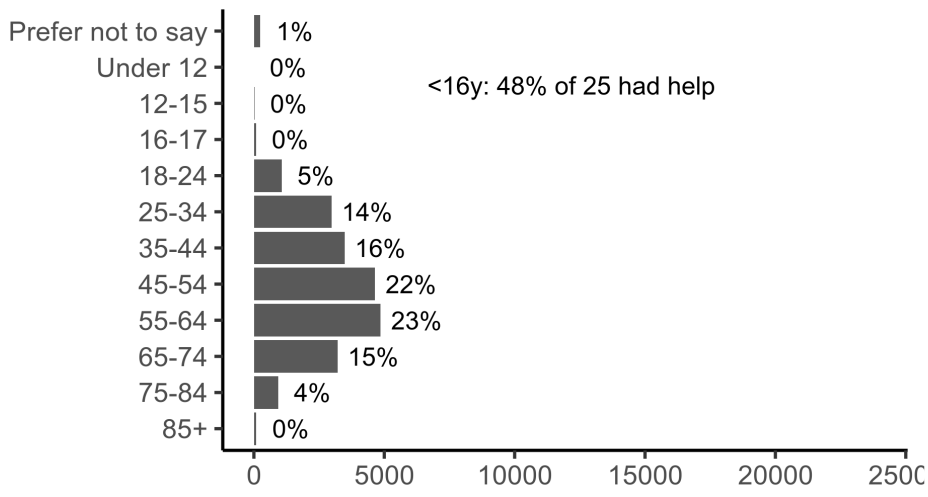

\section{B. Gender}

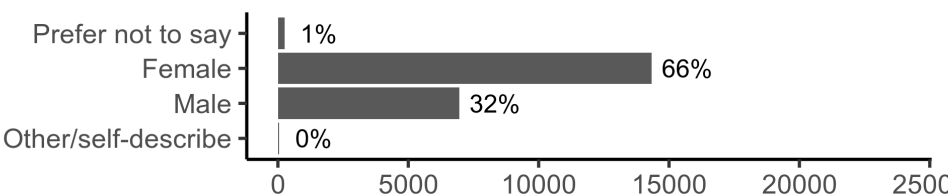

\section{G. Socio-economic classification}

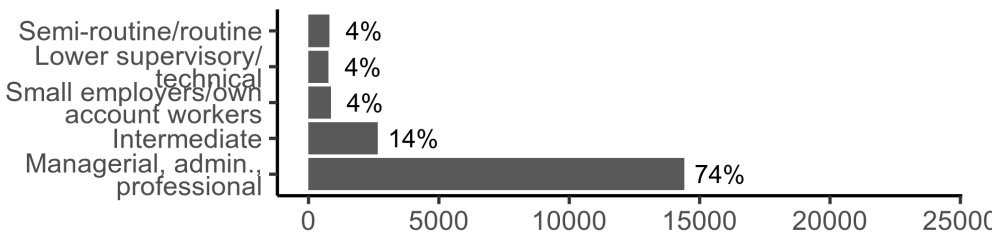

\section{H. Region}

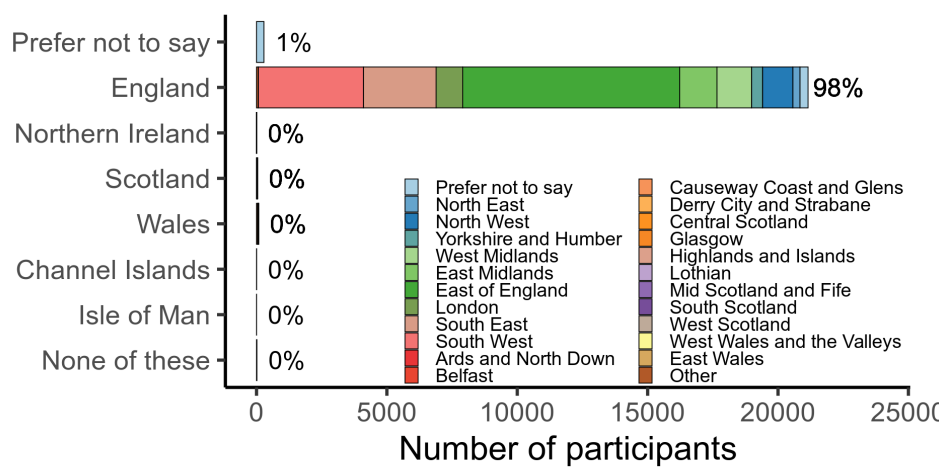

\section{Participants by local authority ( $\dagger$ )}

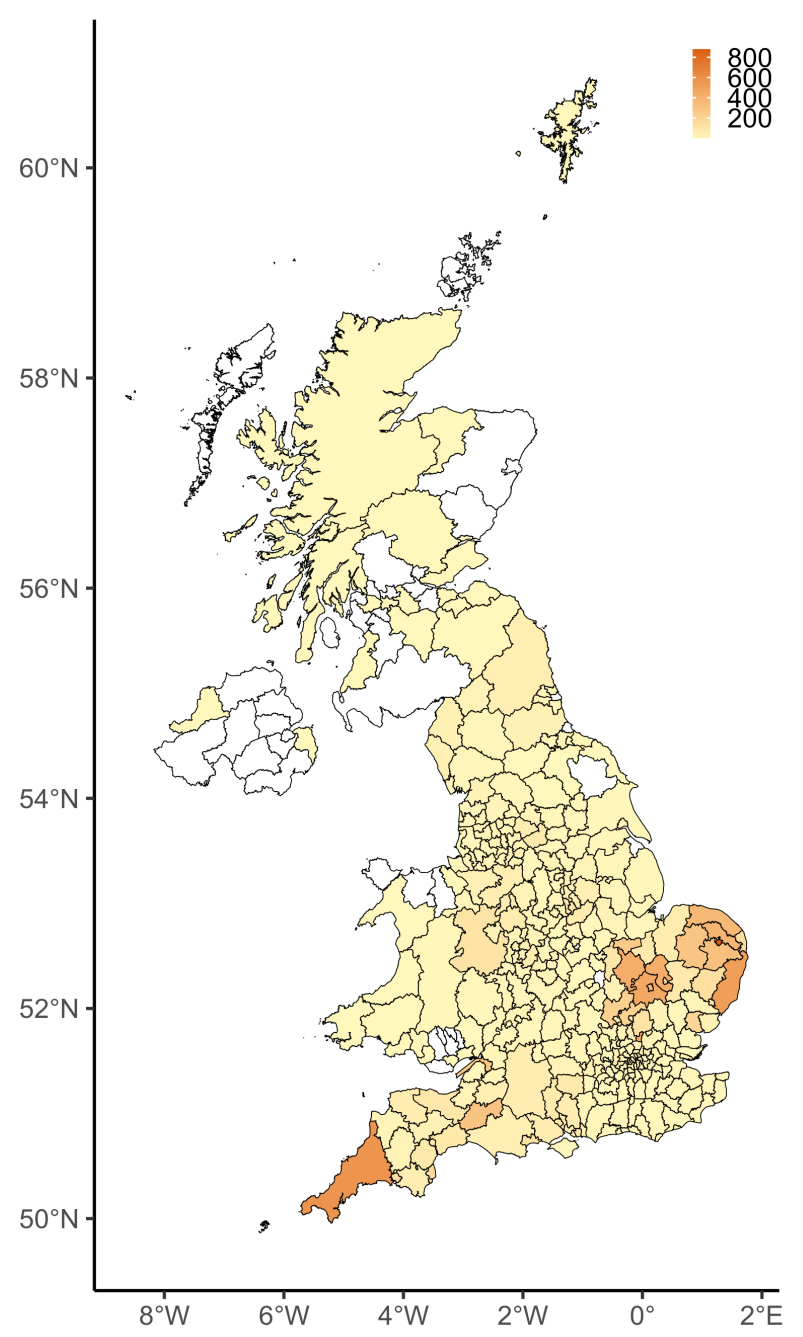

J. UK-wide deprivation distribution (†)

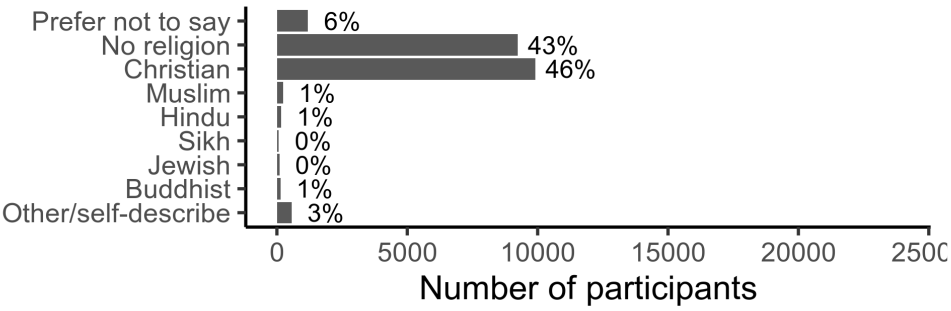


medRxiv preprint doi: https://doi.org/10.1101/2021.07.19.21260635; this version posted July 19,2021 . The copyright holder for this preprint (which was not certified by peer review) is the author/funder, who has granted medRxiv a license to display the preprint in perpetuity.

\section{Supplementary Figure 3}

\section{A. Mental health condition ever?}

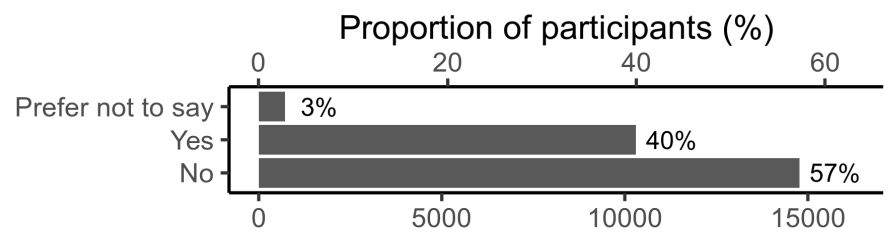

\section{C. [if $\mathrm{MH}+]$ Used mental health services?}

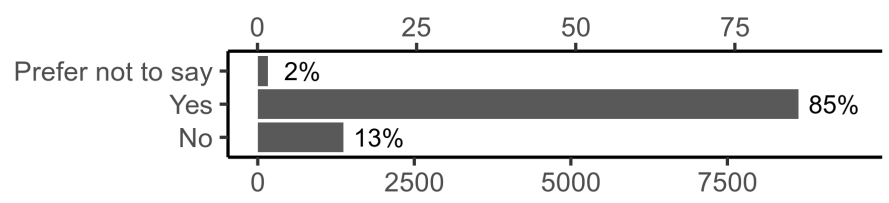

\section{D. [if MHS+] Mental health services}

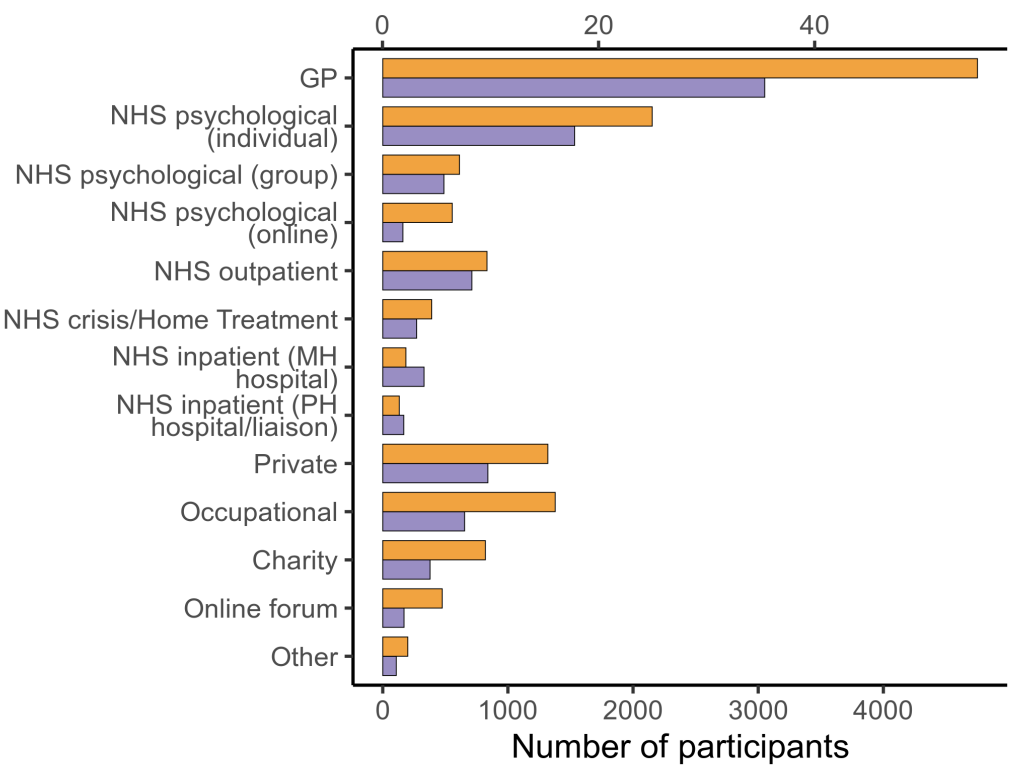

\section{B. [if $\mathbf{M H +}$ ] Mental health conditions}

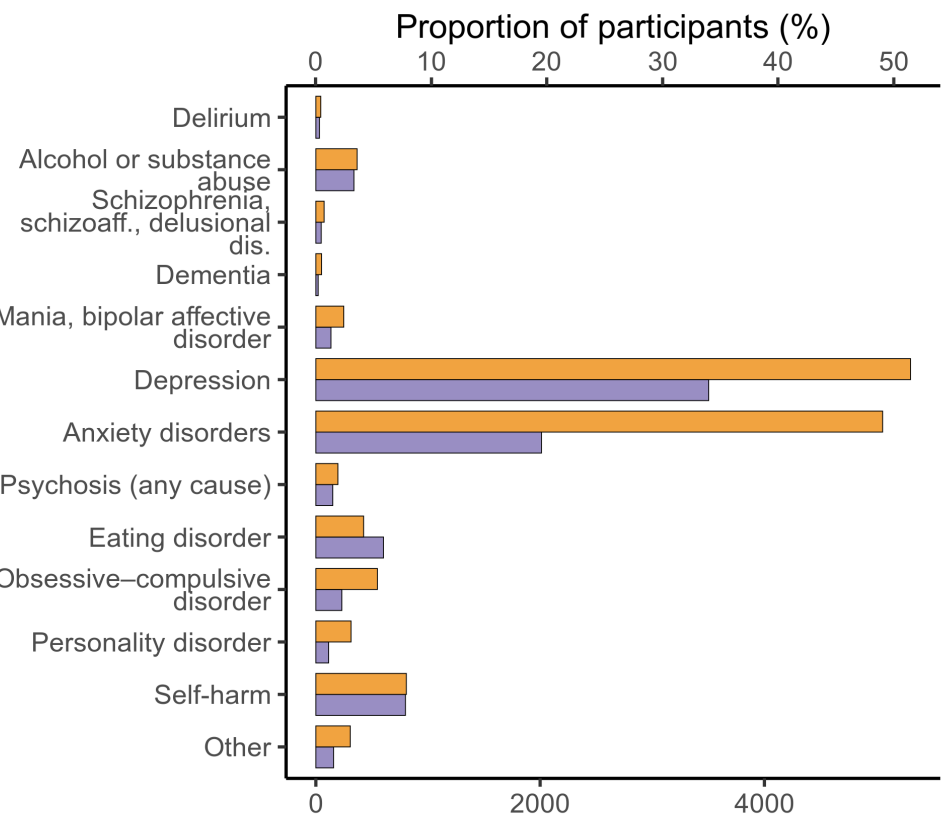

\section{E. Used physical health services?}

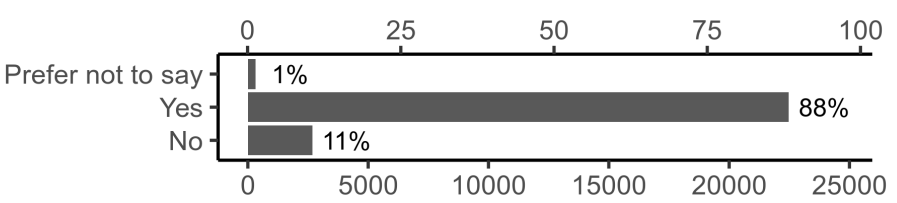

\section{F. [if PHS+] Physical health services}

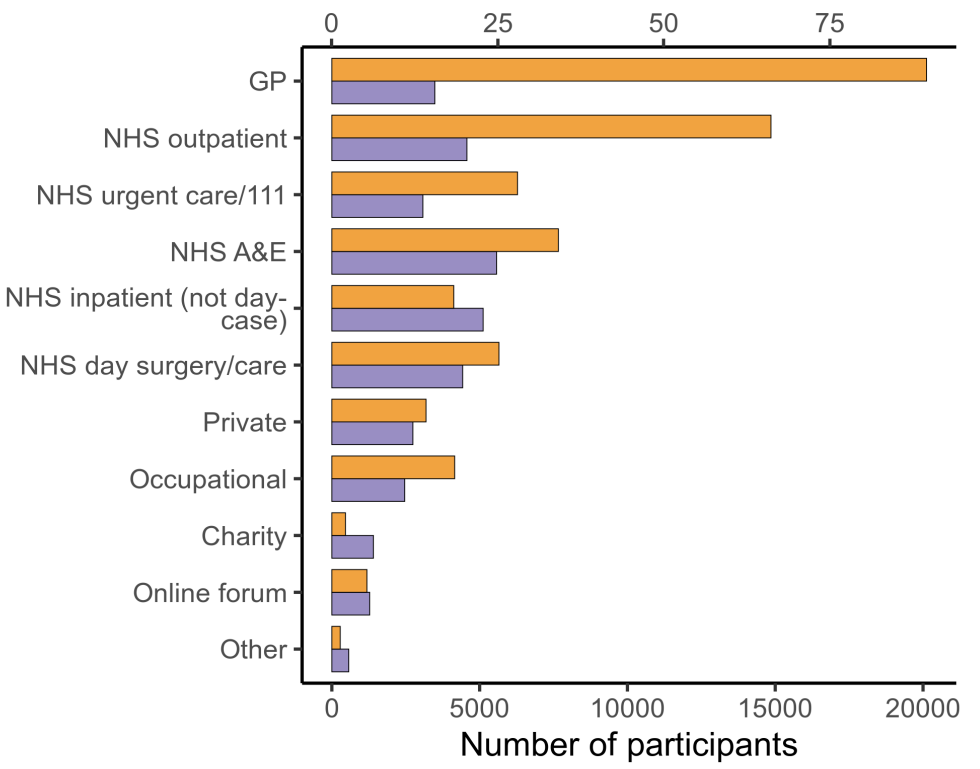

In last $5 y$

$>5 y$ ago 
medRxiv preprint doi: https://doi.org/10.1101/2021.07.19.21260635; this version posted July 19, 2021. The copyright holder for this preprint (which was not certified by peer review) is the author/funder, who has granted medRxiv a license to display the preprint in perpetuity.

It is made available under a CC-BY 4.0 International license .

\section{Supplementary Figure 4}

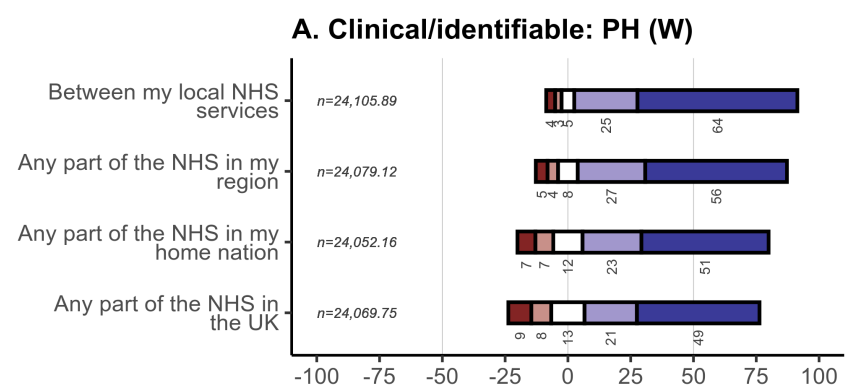

D. Research/de-id., structured: $\mathrm{PH}$ (W)

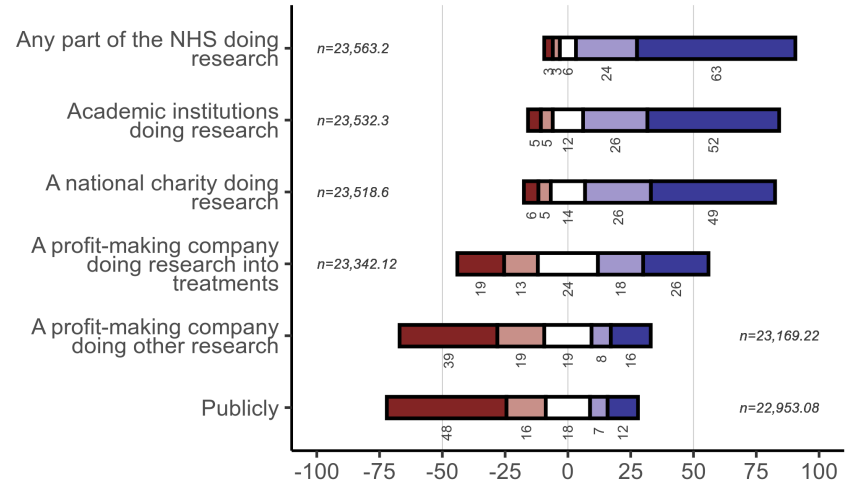

G. Research/de-id., free text: PH (W)

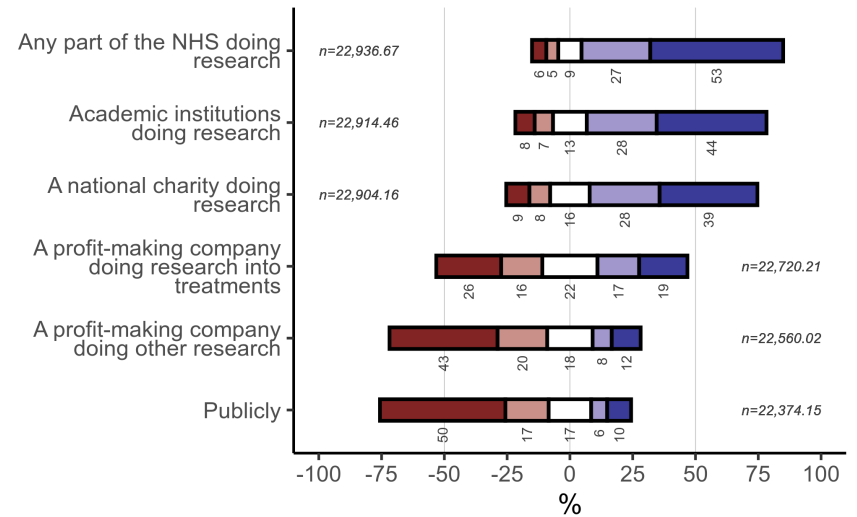

$\square$ Very unlikely $\square$ Unlikely $\square$ Not sure
B. Clinical/identifiable: $\mathrm{MH}$ (W)

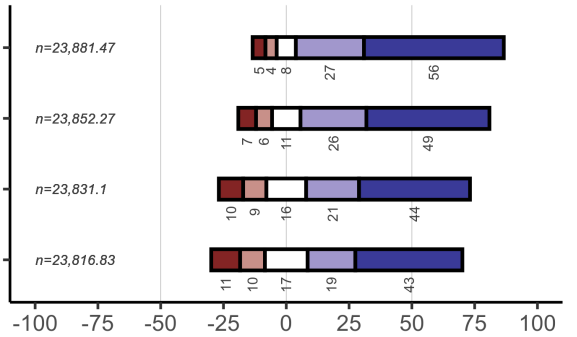

E. Research/de-id., structured: MH (W)

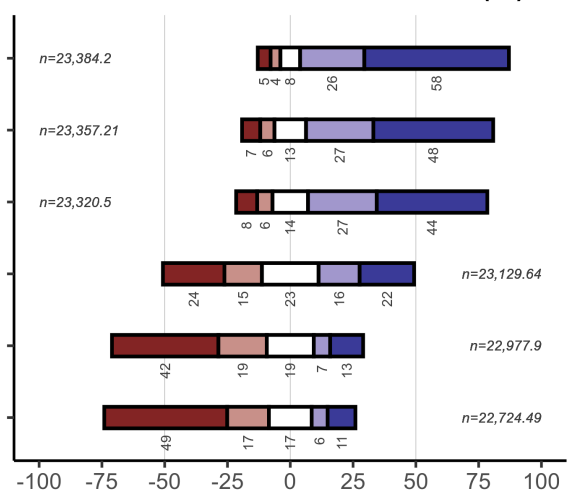

H. Research/de-id., free text: MH (W)

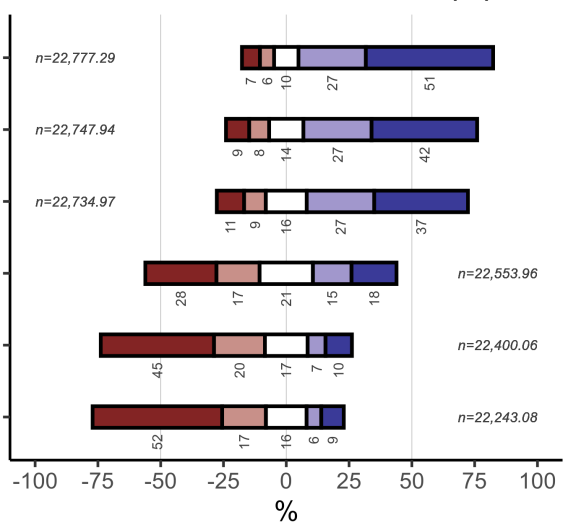

Likely $\square$ Very likely
C. Clinical/identifiable (W)

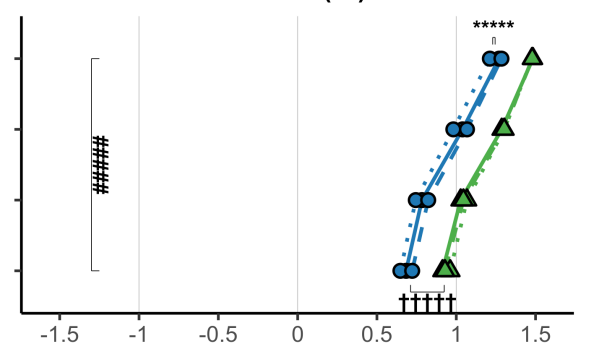

F. Research/de-id., structured (W)

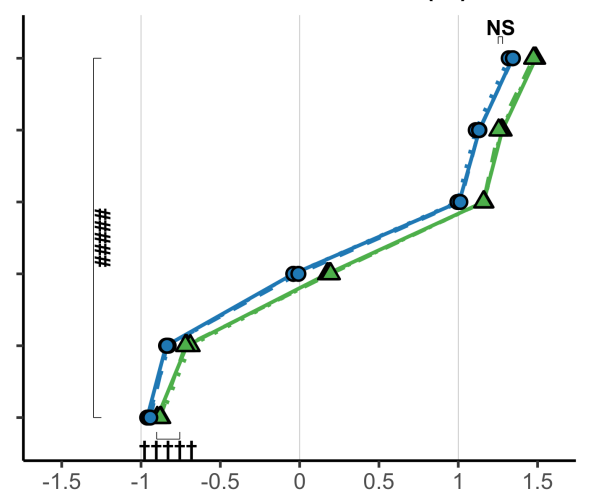

I. Research/de-id., free text (W)

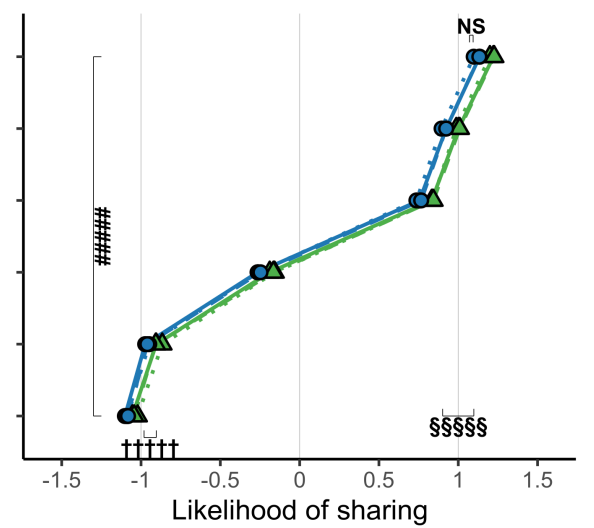


medRxiv preprint doi: https://doi.org/10.1101/2021.07.19.21260635; this version posted July 19, 2021. The copyright holder for this preprint (which was not certified by peer review) is the author/funder, who has granted medRxiv a license to display the preprint in perpetuity.

It is made available under a CC-BY 4.0 International license .

\section{Supplementary Figure 5}

\section{De-identified linkage to non-health data (W)}

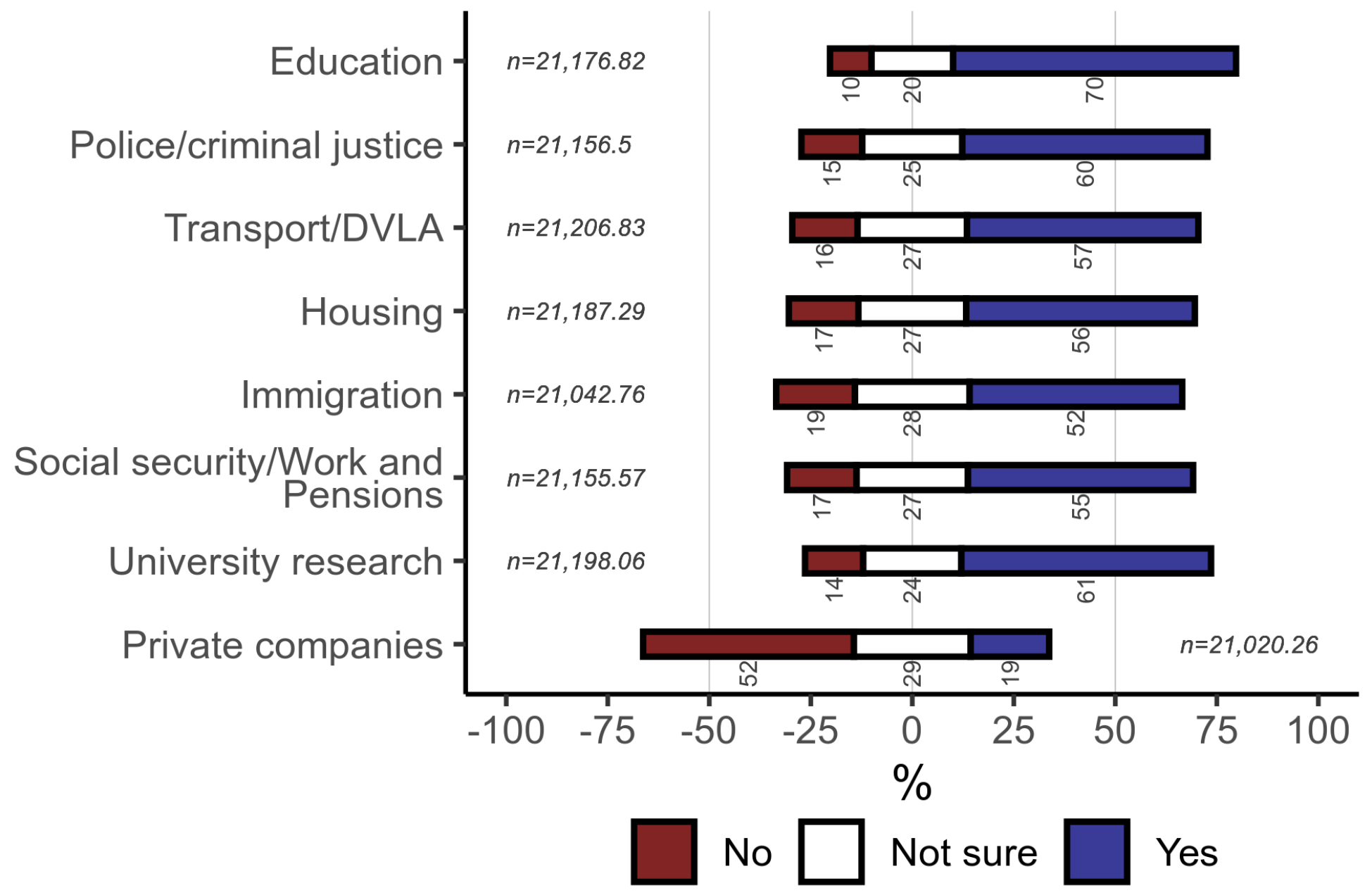


A. Clinical, all participants

Model C1, $n=24497$

(Intercep)

Destination: $F_{3,169348}=6490, p<2.2 \times 10^{-16}(\mathrm{r}+\cdots+\cdots+4)$

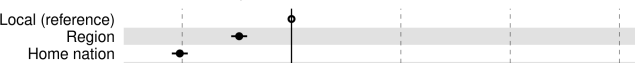

Nature: $F_{1,16983.8}=6080, p<2.2 \times 10^{-16}(\ldots+\cdots$

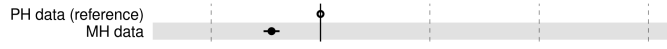
Pandemic: $F_{1,24470.8}=9.86, p=0.0017\left({ }^{* *}\right.$

Betore lockdown (reterence) $\quad-d \quad$ After lockdown $\quad-2$

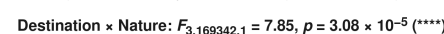

Local OR P P data (reterence)
Region AND $M$ Mdata
Home nation AND M Adata
Whote UK AND MH data

Destination $\times$ Framing: $F_{6,169348}=3.7, p=0.00111$ (")

Local OR Neutral (reference)

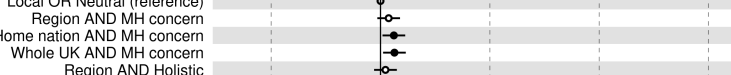
Region AND Holistic
Homenation AND Holitic
Whole UK AND Holisitic

Nature $\times$ Framing: $F_{2,16983.9}=78.4, p<2.2 \times 10^{-16}($ (tw-

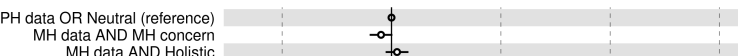

Destination $\times$ Pandemic: $F_{31000}=26 ., p<2.2 \times 10^{-16}($ (…"

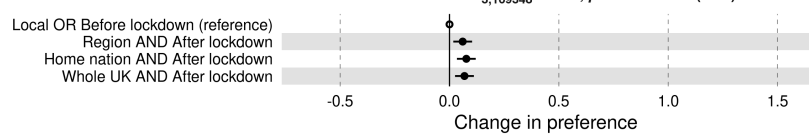

$\quad{ }_{-0.5}^{0.0} \quad{ }^{0.5}{ }^{0.5} \quad 1.5$

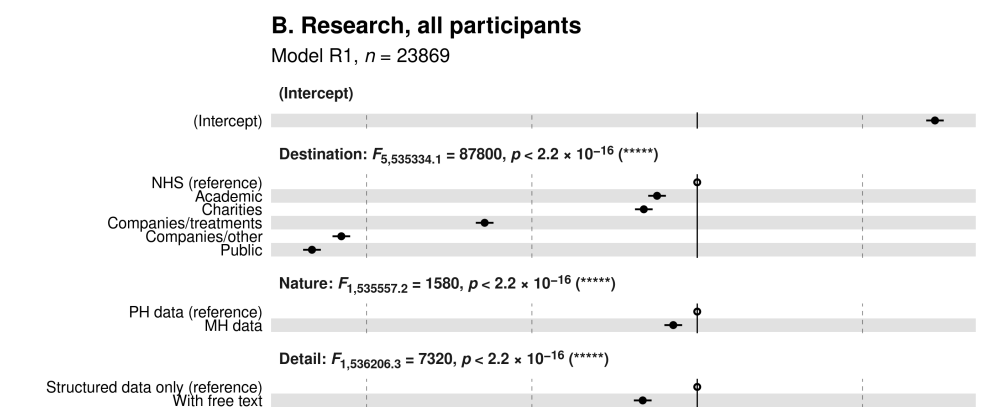

Destination $\times$ Nature: $F_{5,55327.2}=19.8, p<2.2 \times 10^{-16}($ (rm)
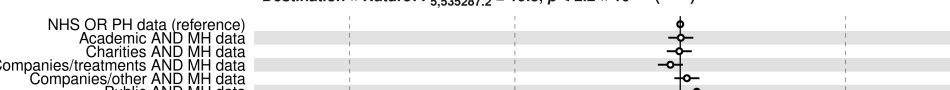

Destination $\times$ Detail: $F_{30502}=95,5, p<22 \times 10^{-16}\left({ }^{2}\right.$

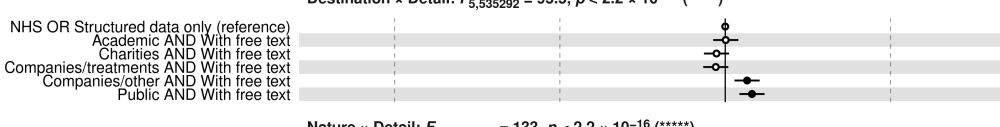

Nature $\times$ Detail: $F_{1,535534.7}=133, p<2.2 \times 10^{-16}($ (m)

PH data OR Structured data only (reference)

$$
f_{+\infty}
$$

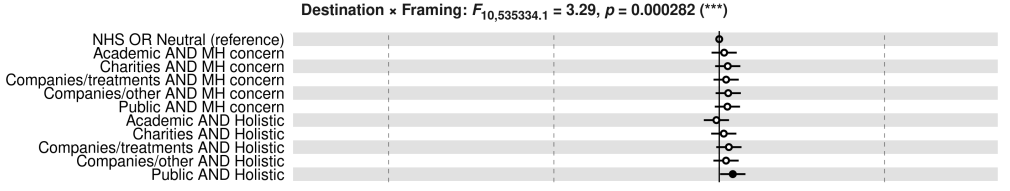
Nature $\times$ Framing: $F_{2,535577.4}=5.95, p=0.00261$ ("*)

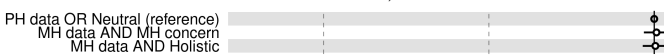

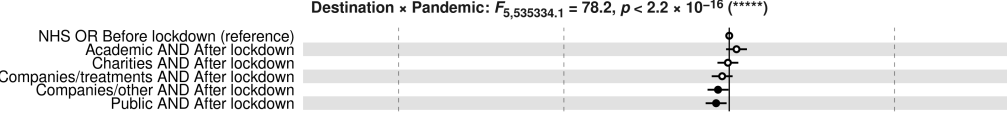

Detail $\times$ Pandemic: $F_{15302033}=22.2, p=2.44 \times 10^{-6}(\cdots+\cdots$

Structured data only OR Beferel lockdown (reference)
With tree text AND After lockdown Framing $\times$ Pandemic: $F_{2,23333,3}=4.42, p=0.012$

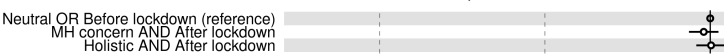

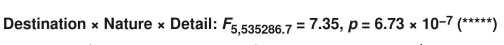
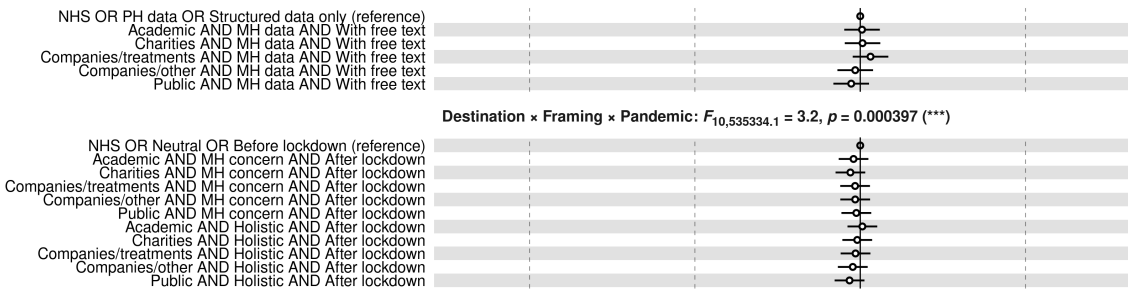

Detail × Framing $\times$ Pandemic: $F_{2,536205.8}=6.19, p=0.00204$ ("*)

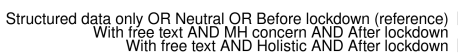

Change in preference
C. Linkage, all participants

C.Ldil $L 1, n=21615$

(Intercept)

(Intercept) $\quad \begin{aligned} & \mid \\ & 0\end{aligned}$

Source: $F_{7,15079.8}=7300, p<2.2 \times 10^{-16}($ (m)

education (reference) $\quad$.

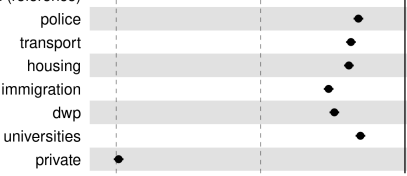

private

Source $\times$ Pandemic: $F_{7} 1507998=6.21, \rho=2.7 \times 10^{-7}(m-m$

education OR Befóre lockdown (reference

police AND After lockdow

housing AND After lockdow

dwp AND After lockdown
Dersities AND Ater lockdown

private AND After lockdown

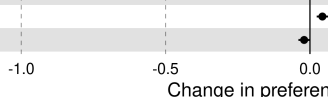


medRxiv preprint doi: https://doi.org/10.1101/2021.07.19.21260635; this version posted July 19, 2021. The copyright holder for this preprint (which was not certified by peer review) is the author/funder, who has granted medRxiv a license to display the preprint in perpetuity.

It is made available under a CC-BY 4.0 International license .

\section{Supplementary Figure 7}

\section{A. Expressing choice nationally via... (W)}

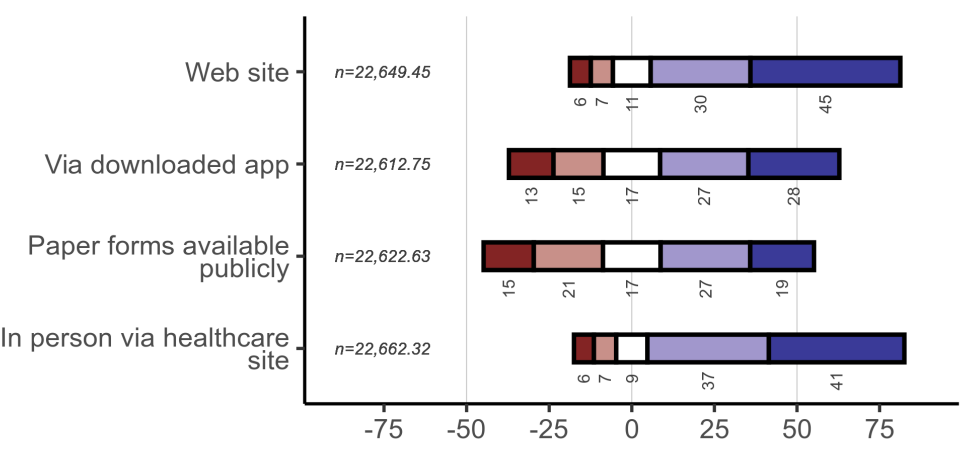

B. Expressing choice, if data held by... (W)

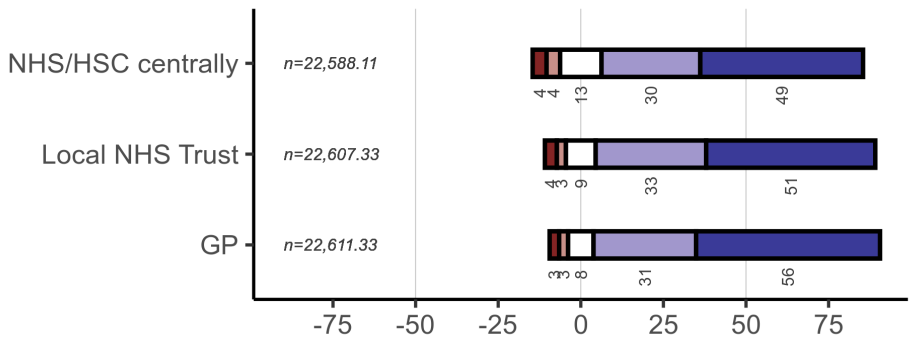

C. Changing preferences via... (W)

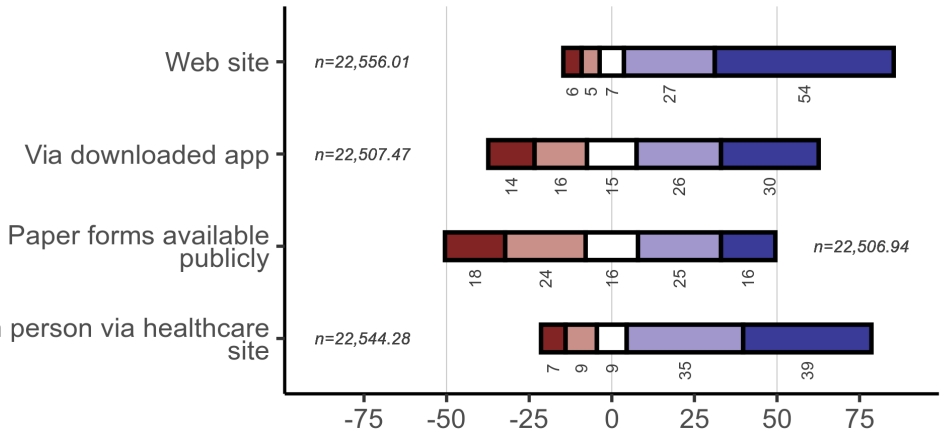

\section{Overall (W)}

Overall likelihood of signing up

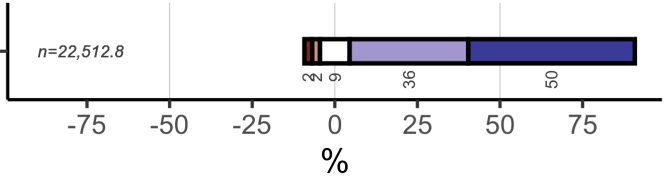

\begin{tabular}{l}
$\square$ Very unlikely \\
\hline$\square$ Unlikely \\
\hline$\square$ Not sure \\
Likely \\
Very likely
\end{tabular}

\section{E. Web sites for research participation (W)}

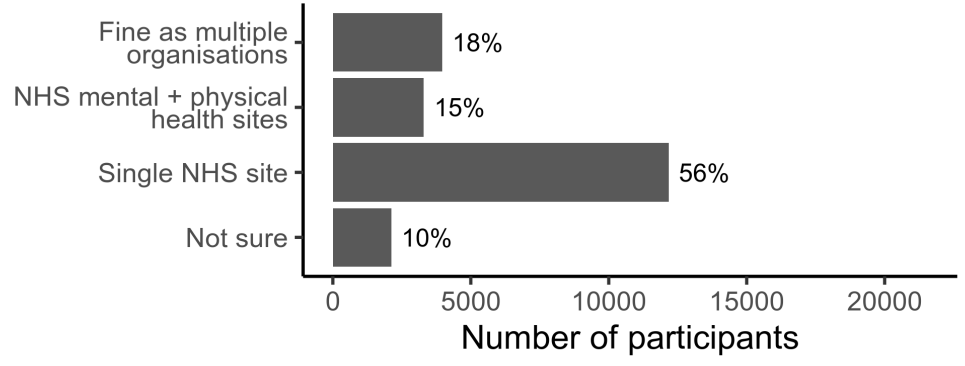

\section{F. Specimen consent form (W)}

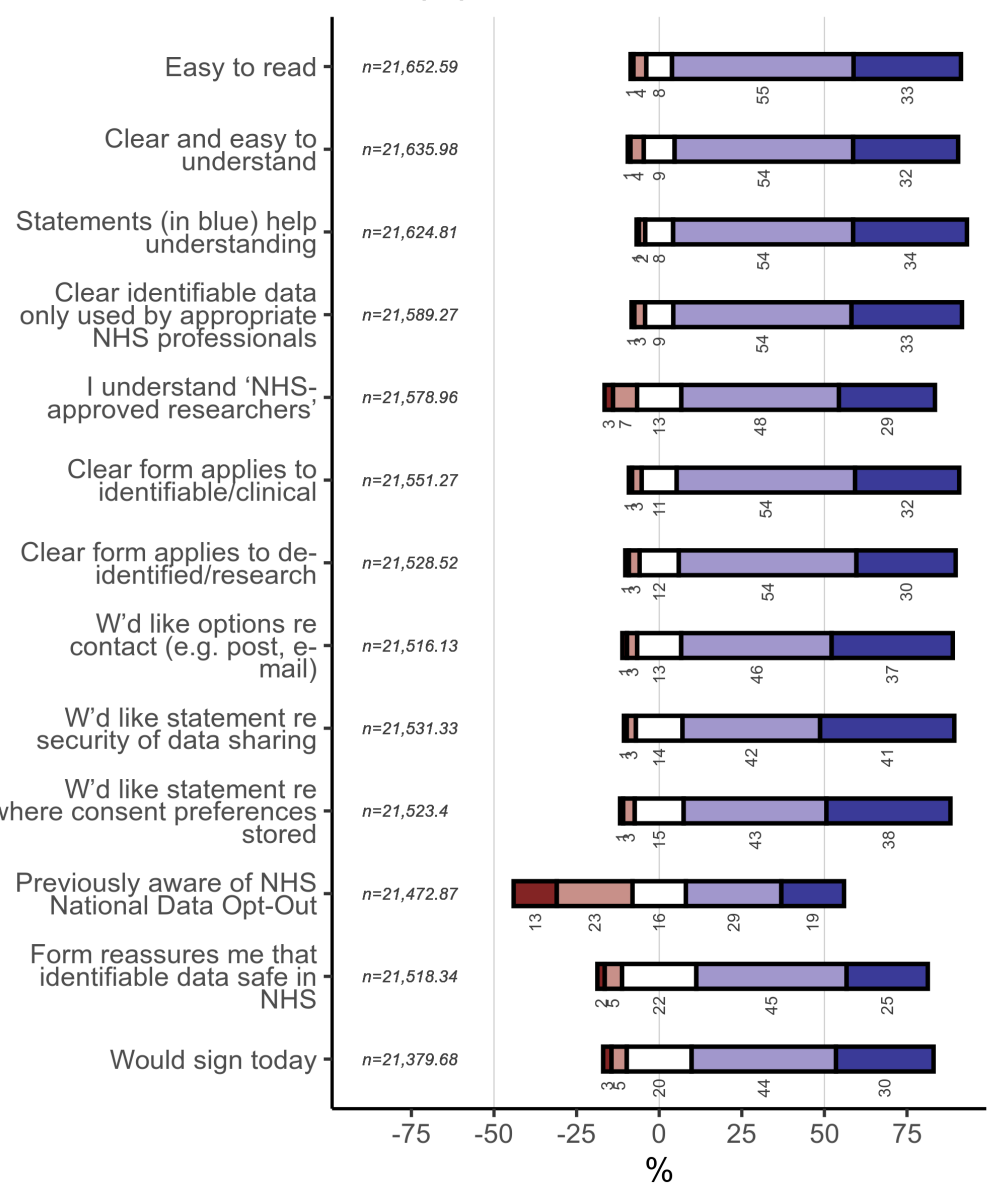

Strongly disagree

Disagree

Neither agree nor disagree

Agree

Strongly agree 


\title{
University of Cambridge NHS Health Data Consent Survey
}

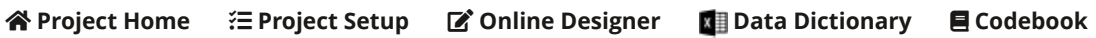

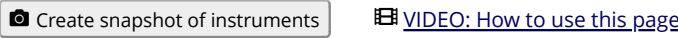
Last snapshot: 28/08/2019 10:22am ?

This page allows you to build and customize your data collection instruments one field at a time. You may add new fields or edit existing ones. New fields may be added by clicking the Add Field buttons. You can begin editing an existing field by clicking on the Edit icon. If you decide that you do not want to keep a field, you can simply delete it by clicking on the $\mathbf{x}$ Delete icon. To reorder the fields, simply drag and drop a field to a different position within the form below. NOTE: While in development status, all field changes will take effect immediately in real time. Are you using Action Tags yet? If not, learn about Action Tags here.

\section{Return to list of instruments Survey settings}

Current instrument: NHS Data Consent Survey

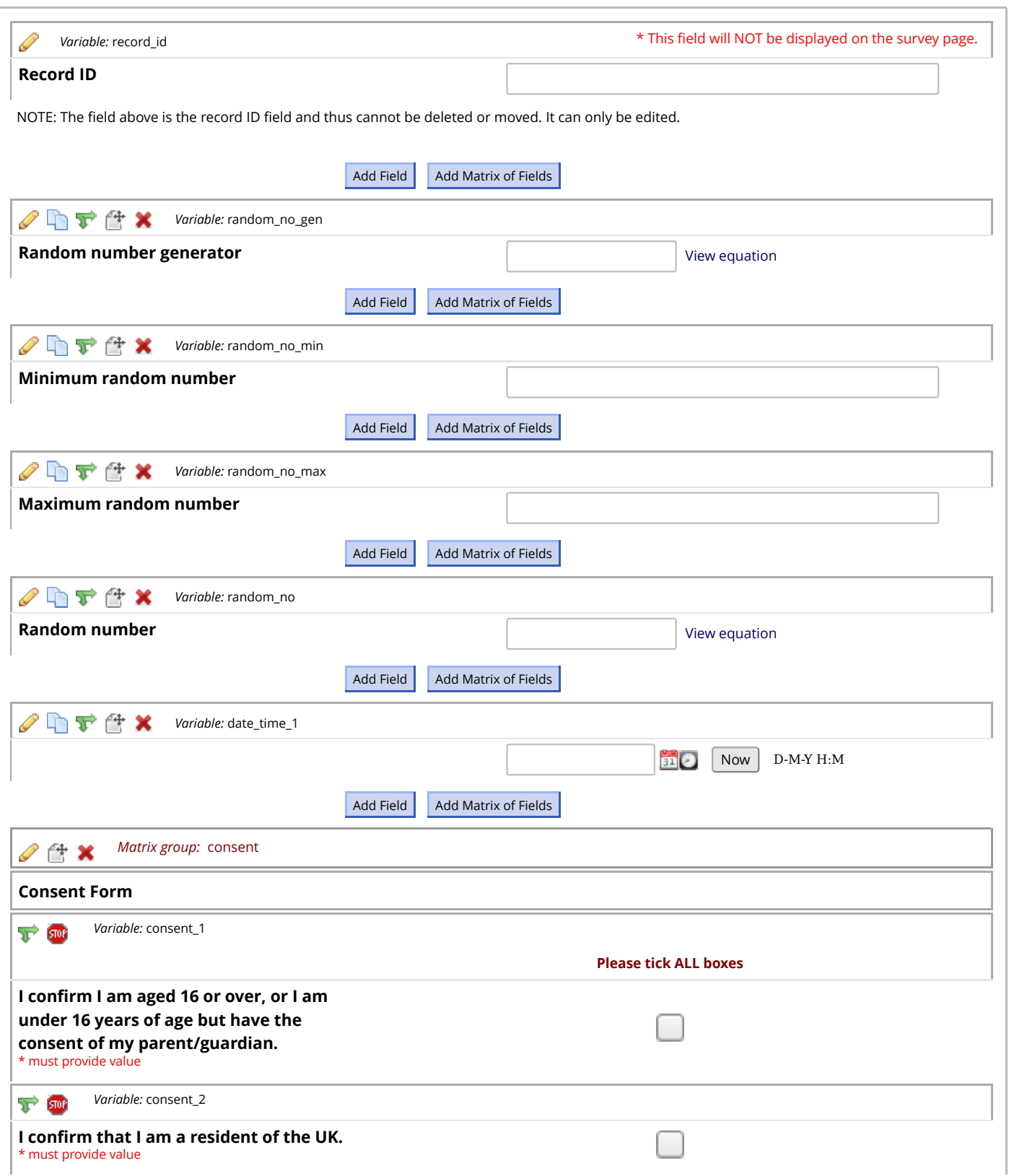




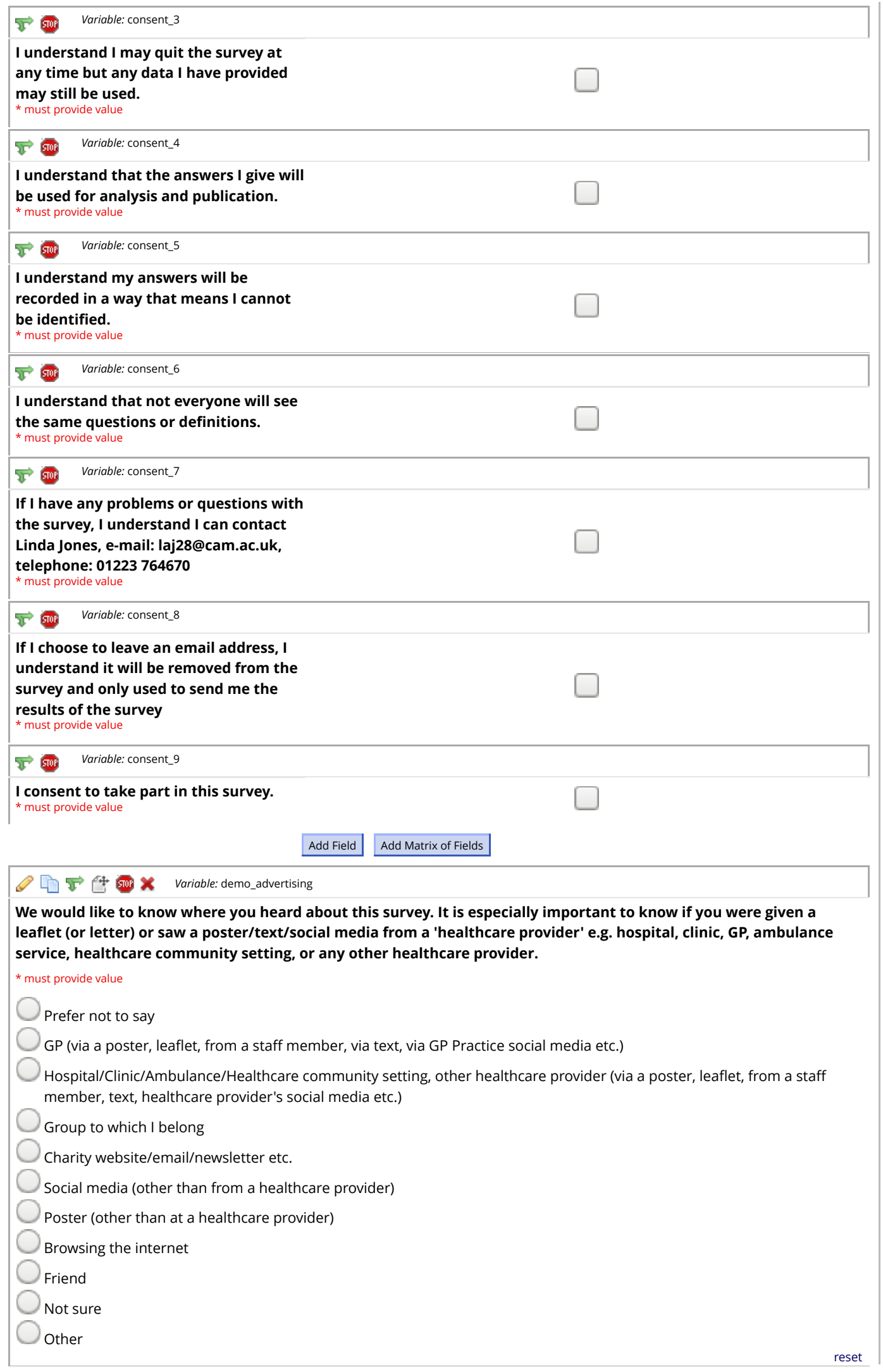




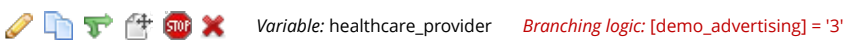

Please could you tell us in which healthcare establishment you saw a poster or picked up/were given a leaflet? If you have the leaflet, the healthcare setting may be named on the back of it. This is really important to each healthcare provider. (Please type in a few letters and options will appear.)

* must provide value

Add Field Add Matrix of Fields

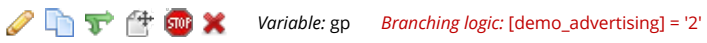

Please could you tell us in which GP Practice (surgery) you saw a poster or picked up/were given a leaflet? If you have the leaflet, the practice may be named on the back of it. This is really important to the GPs. (Please type in a few letters and options will appear.)

* must provide value

Add Field Add Matrix of Fields

$\mathbf{x}$

Before starting the survey please read the following definitions:

By "NHS" we mean all parts of the national health service in the UK: NHS England, NHS Scotland, NHS Wales, and Health and Social Care in Northern Ireland (HSC). We refer to all these as the NHS in this survey.

Health data means any information about a person's health such as might be collected by a nurse, doctor or other appropriate member of NHS staff. Health data includes things like your medical notes, blood test results, prescription information, scans, etc.

Identifiable health data means any health data (as described above) that can also identify a person -- such as any health data that also contains names, addresses, NHS numbers, etc.

Clinical care means providing health care directly to people -- for example, diagnosing illnesses or treating ill health.

Add Field Add Matrix of Fields

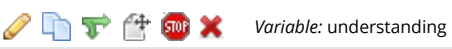

We would like to know/gauge your understanding of how NHS clinical care providers currently share your identifiable health data for your clinical care, without asking you each time. If you are not sure, please have a "best guess" as to what you think might happen.

My understanding is that (please tick only one):

* must provide value

My identifiable health data is currently shared freely between all NHS sites across the UK -- i.e. all acute hospital Trusts, my GP, all mental health Trusts, ambulance services, etc., in the whole UK.

My identifiable health data is currently shared between all NHS sites but only in the home nation that I live in -- i.e. shared only in England, or Scotland, or Northern Ireland, or Wales, but not between them.

My identifiable health data is currently only shared between NHS sites in my region (cluster of hospitals nearest to my local hospital).

My identifiable health data is currently only shared between my GP, acute local hospital, local mental health Trust, and other local services.

My identifiable health data is currently not shared between any NHS sites.

Add Field Add Matrix of Fields

\section{$\mathrm{x}$}

MOST hospital Trusts, GPs, mental health Trusts are separate and currently DO NOT share identifiable health data without asking you, though they correspond and communicate with each other with your permission. 


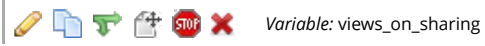

In view of the statement above, we would now like to ask you your views on sharing your own identifiable health data for YOUR CLINICAL CARE, without having to be asked each time (please tick only one):

* must provide value

I would like my identifiable health data to be shared for clinical purposes with any part of the NHS in the UK, without asking me first.

I would like my identifiable health data to be shared for clinical purposes with any part of the NHS in my home nation only (i.e. only in England, or only in Northern Ireland, or only in Scotland, or only in Wales) without asking me first.

I would like my identifiable health data to be shared for clinical purposes with any part of my region (cluster of hospitals nearest to my local hospital), without asking me first.

I would like my identifiable health data to be shared for clinical purposes only with my GP, local hospital, and local mental health services, without asking me first.

No one in the NHS should share my identifiable health data without asking me first.

Not sure.

[

Add Field Add Matrix of Fields

$0 \times$

We would now like to ask you some questions about your own MENTAL and PHYSICAL health. You can "prefer not to say" if you wish.

Add Field Add Matrix of Fields

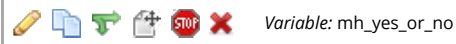

We would like to ask if you have had a MENTAL health condition either recently or at some point in your life.

By mental health conditions we include things like delirium, self harm, substance abuse, dementia, mania, schizophrenia, depression, anxiety disorders, psychosis, eating disorders, OCD, personality disorders, etc.

* must provide value

I prefer not to say.

Yes, I have had a mental health condition either recently or at some point in my life.

No, I have never had a mental health condition.

Add Field Add Matrix of Fields

4 4 Matrix group: mh_conditions

We would like to know if you would be willing to share what mental health condition you have had.

You may tick as many boxes as you wish.

If you prefer not to say, please use the "next page" button below to move on.

$\overrightarrow{2}$ G10 Variable: delirium Branching logic: [mh_yes_or_no] = '1'

In the last 5 years

More than 5 years ago

Delirium

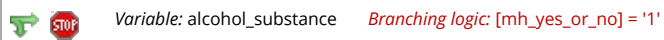

Alcohol or substance abuse

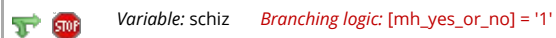

Schizophrenia, schizoaffective disorder

or delusional disorder

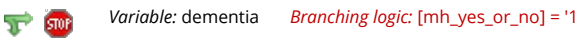

Dementia 


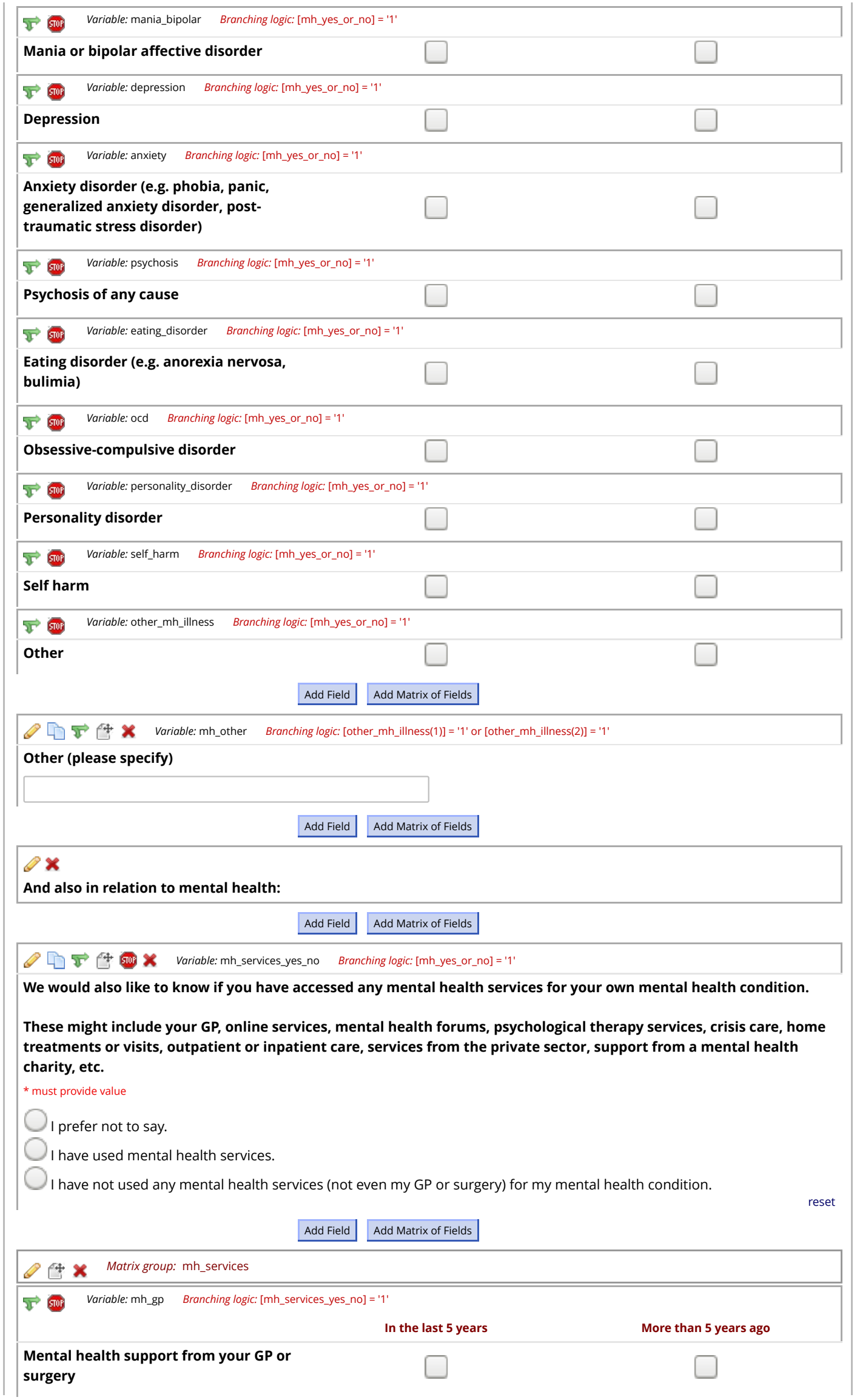




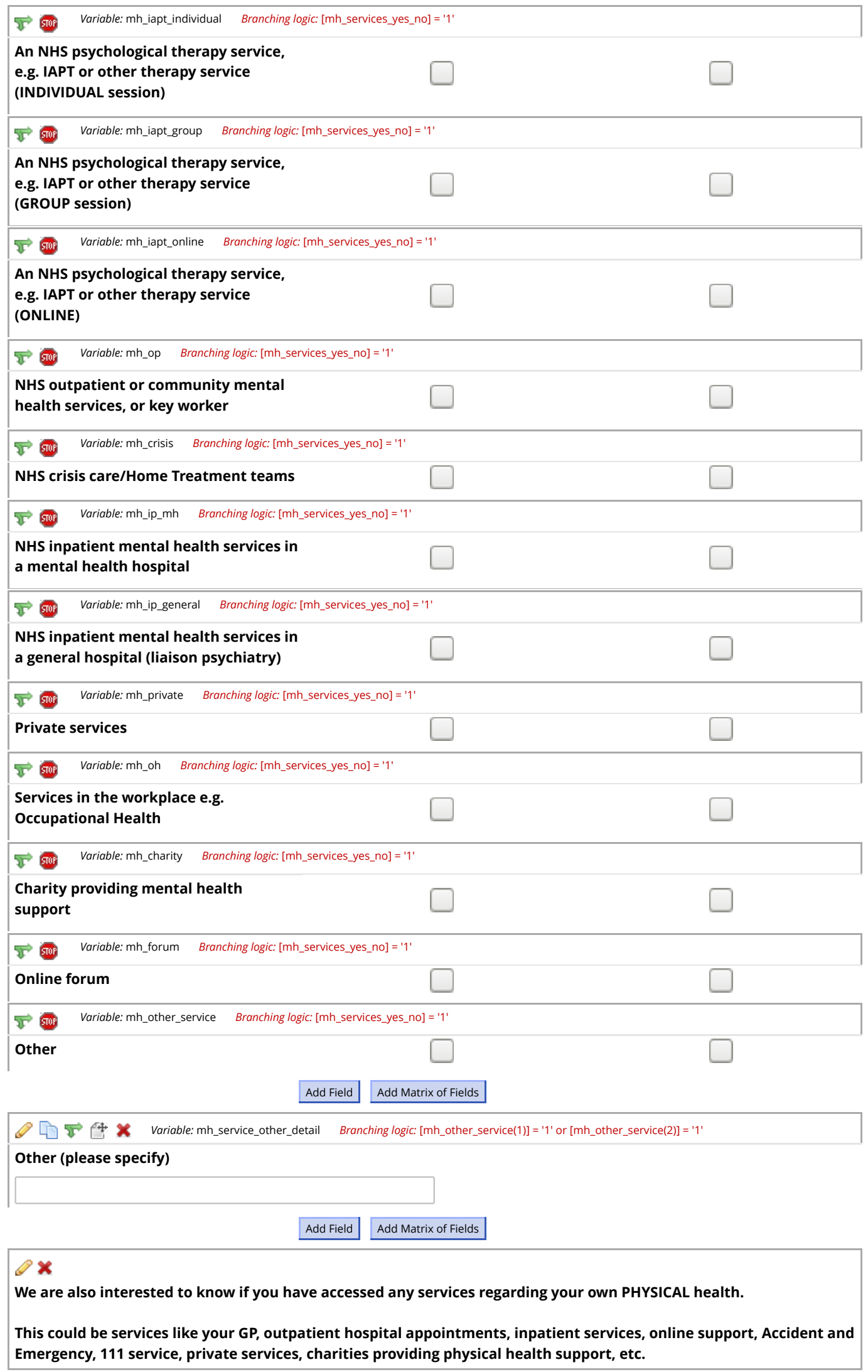




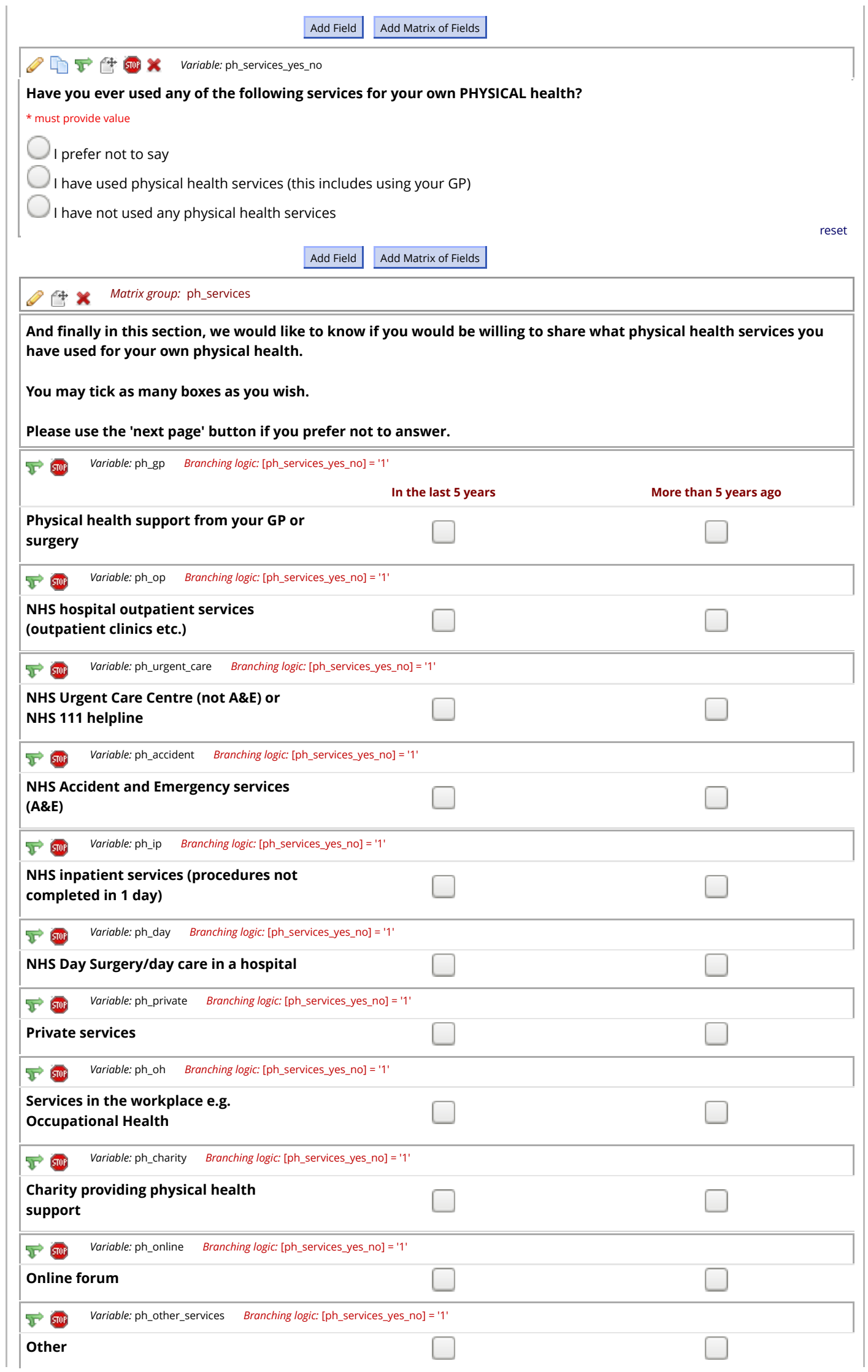




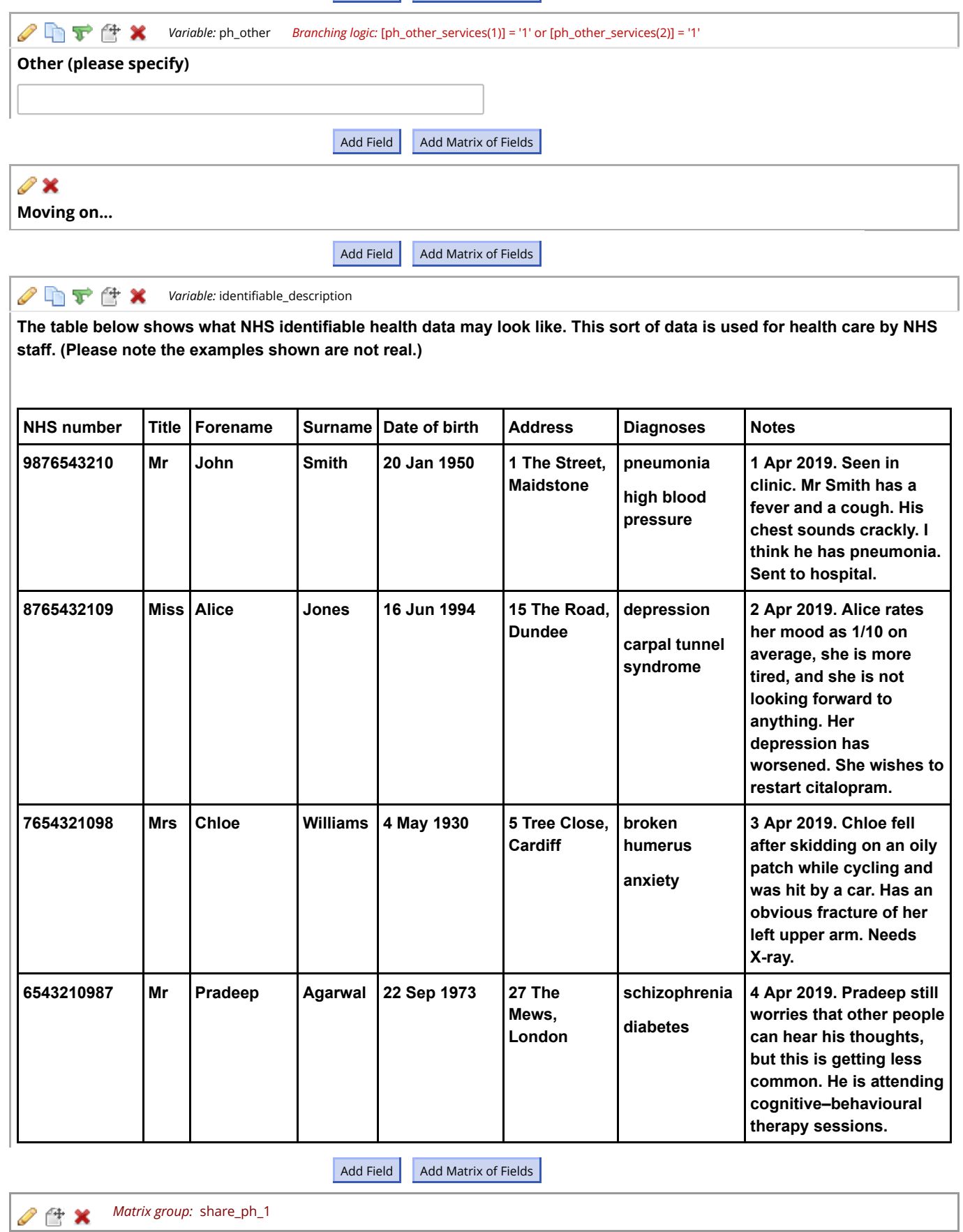

Previous surveys have found that people have more concerns about the use of their identifiable health data relating to their mental health than other aspects of their physical health care.

Regardless of whether you have a PHYSICAL health condition or have used PHYSICAL health services:

How likely are you to agree to share your identifiable PHYSICAL health data for your clinical care with the following, without being asked every time? 


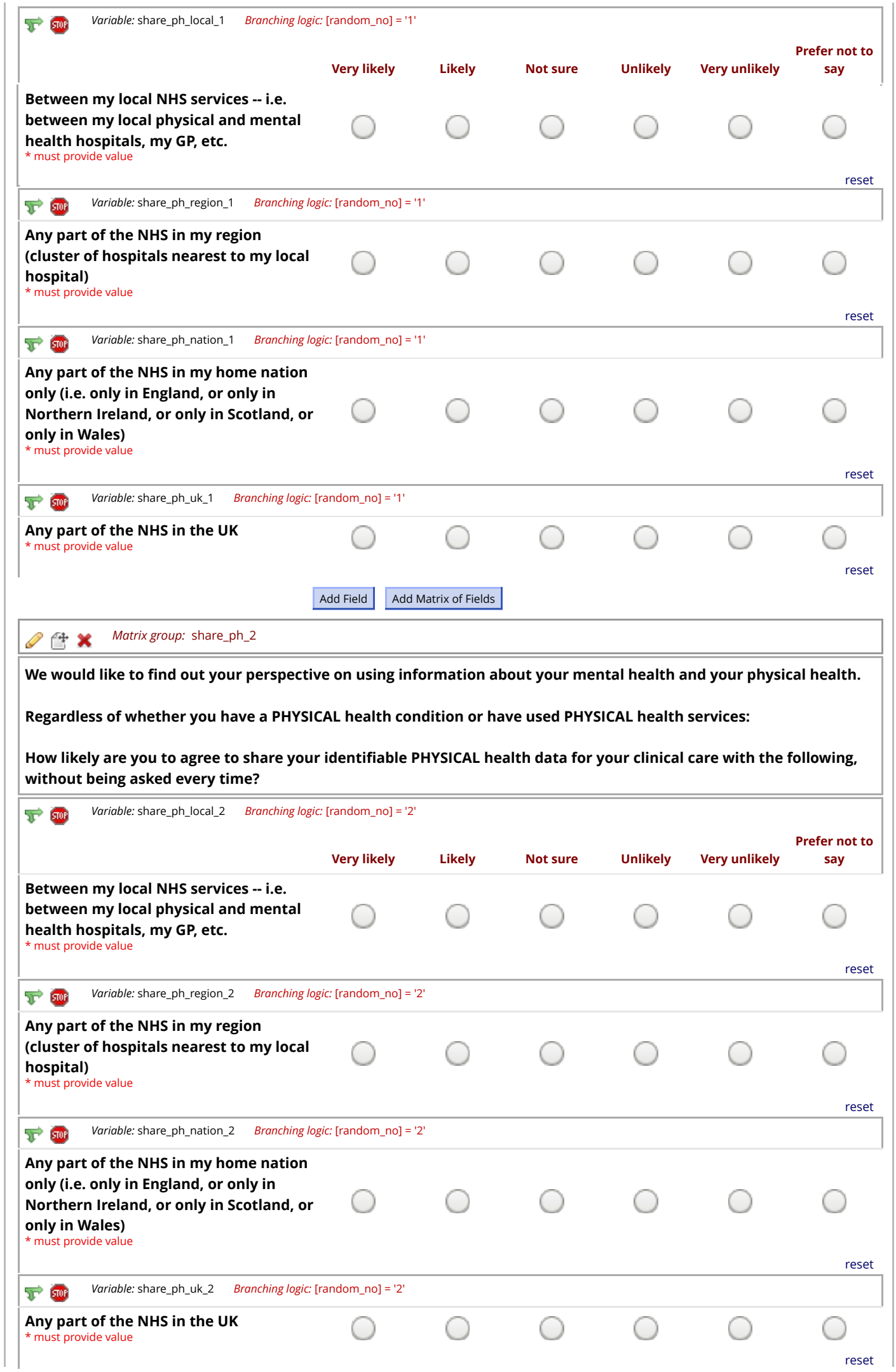




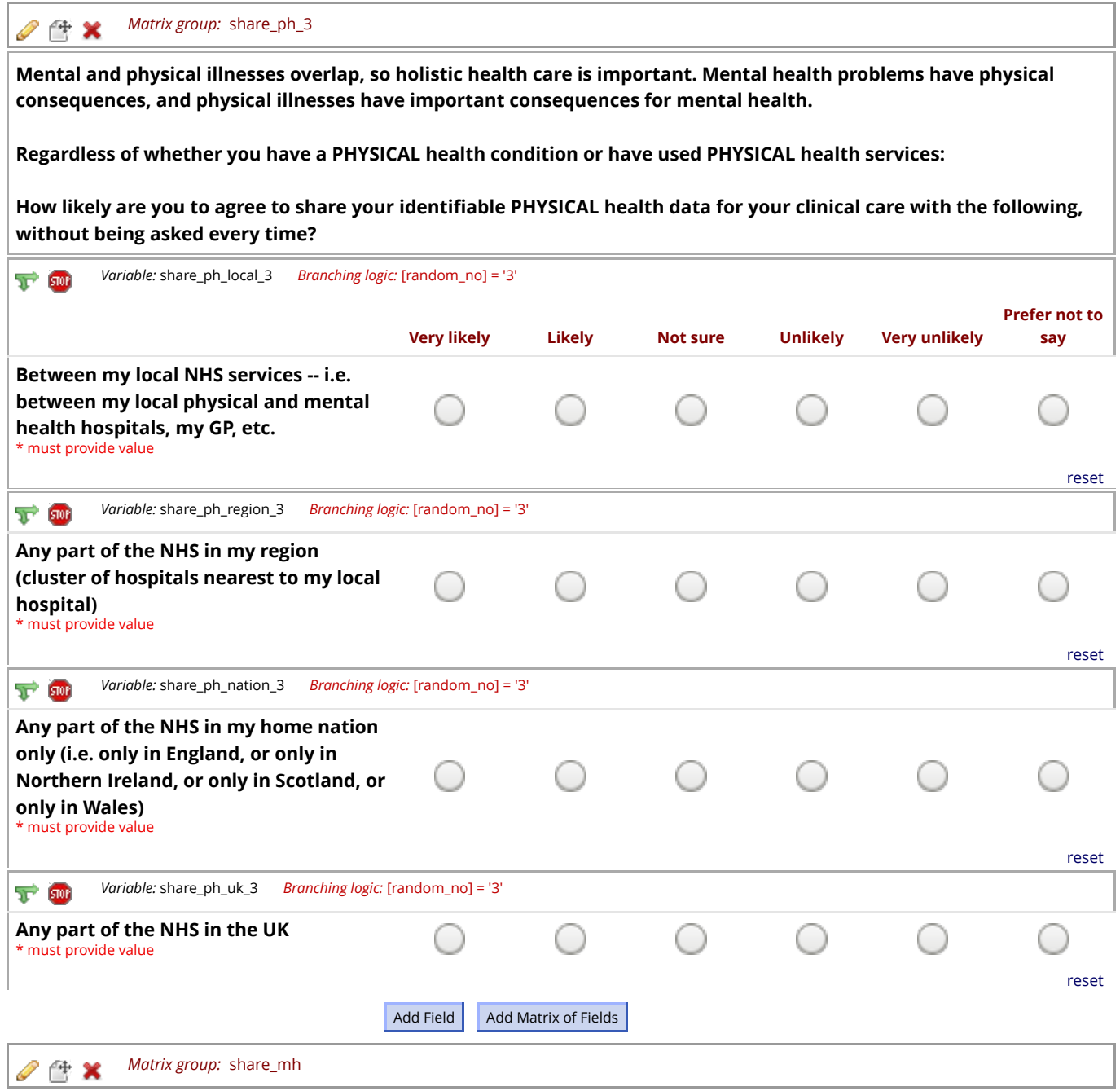

Regardless of whether you have a MENTAL health condition or have used MENTAL health services:

How likely are you to agree to share your identifiable MENTAL health data for your clinical care with the following, without being asked every time?

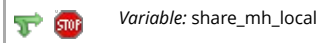

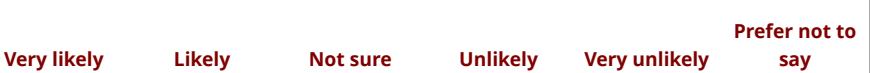

Between my local NHS services -- i.e.

between my local physical and mental

health hospitals, my GP, etc.

* must provide value

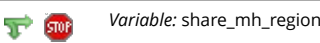

Any part of the NHS in my region

(cluster of hospitals nearest to my local

hospital)

* must provide value 


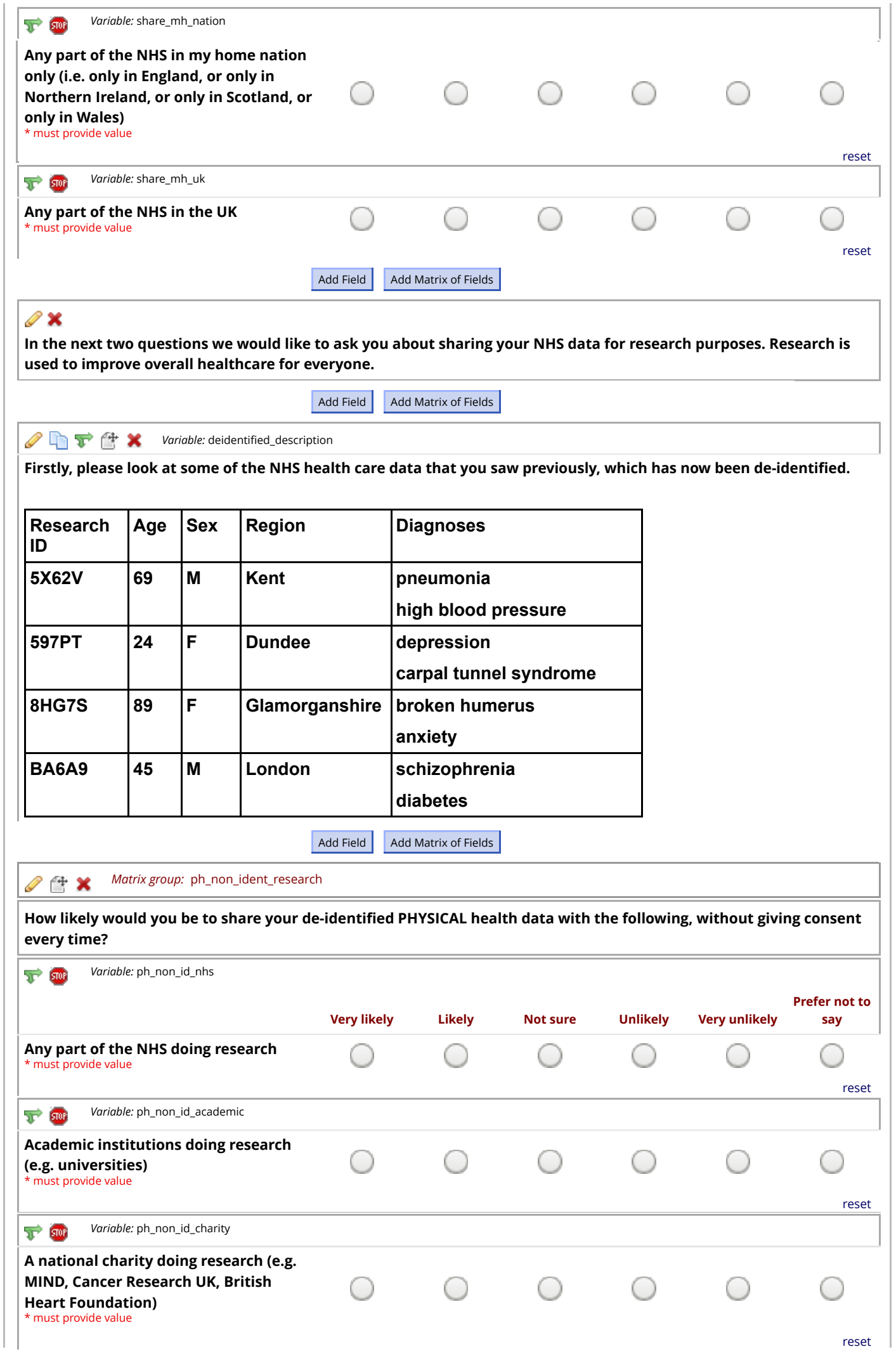




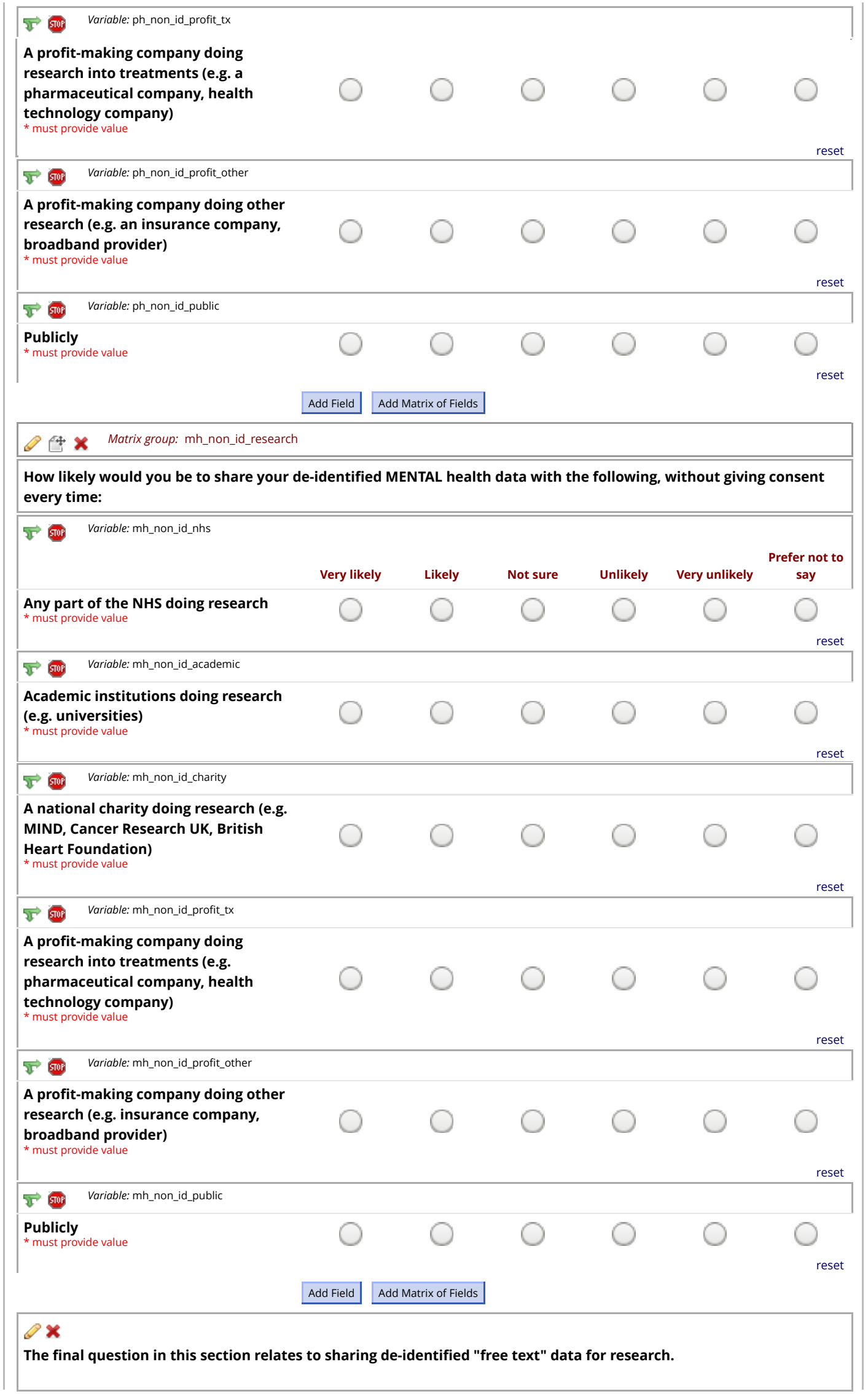




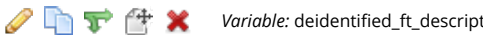

Here is the table of de-identified health care data you saw earlier, but this time a column labelled "Notes" has been added. This is known as "free text" data.

\begin{tabular}{|c|c|c|c|c|c|}
\hline $\begin{array}{l}\text { Research } \\
\text { ID }\end{array}$ & Age & Sex & Region & Diagnoses & Notes \\
\hline $5 \times 62 V$ & 69 & M & Kent & $\begin{array}{l}\text { pneumonia } \\
\text { high blood pressure }\end{array}$ & $\begin{array}{l}1^{\text {st }} \text { April 2019. XXX has a fever and } \\
\text { cough. His chest sounds crackly. I } \\
\text { think he has pneumonia. Sent to } \\
\text { hospital. }\end{array}$ \\
\hline 597PT & 24 & $\mathbf{F}$ & Dundee & $\begin{array}{l}\text { depression } \\
\text { carpal tunnel } \\
\text { syndrome }\end{array}$ & $\begin{array}{l}2^{\text {nd }} \text { April 2019. XXX rates her mood as } \\
1 / 10 \text { on average, she is more tired, and } \\
\text { she is not looking forward to anything. } \\
\text { Her depression has worsened. She } \\
\text { wishes to restart citalopram. }\end{array}$ \\
\hline 8HG7S & 89 & $\mathbf{F}$ & Glamorganshire & $\begin{array}{l}\text { broken humerus } \\
\text { anxiety }\end{array}$ & $\begin{array}{l}3^{\text {rd }} \text { April 2019. XXX fell after skidding } \\
\text { on an oily patch while cycling and was } \\
\text { hit by a car. She has an obvious } \\
\text { fracture of her left upper arm. She } \\
\text { needs an X-ray. }\end{array}$ \\
\hline BA6A9 & 45 & M & London & $\begin{array}{l}\text { schizophrenia } \\
\text { diabetes }\end{array}$ & $\begin{array}{l}4^{\text {th }} \text { April 2019. XXX still worries that } \\
\text { other people can hear his thoughts, } \\
\text { but this is getting less common. He is } \\
\text { attending cognitive-behavioural } \\
\text { therapy sessions. }\end{array}$ \\
\hline
\end{tabular}

Like the last example the data remains de-identified but gives the researchers more information. As there is more information there is a slightly increased risk of someone being identified from the data.

For example, in the table above, an "89-year-old cyclist skidding on oil and being hit by a car" may be reported in a local newspaper. Whilst the lady is not named in the data above, she would almost certainly be named in the newspaper and it may therefore be possible for researchers to work out who she is.

\section{Add Field Add Matrix of Fields}

\section{Matrix group: ph_free_text}

How likely would you be to share your FREE TEXT de-identified PHYSICAL health data with the following, without giving consent every time:

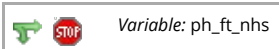

$\begin{aligned} & \text { Any part of the NHS doing research } \\ & \text { * must provide value }\end{aligned}$
reset

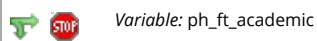

Academic institutions doing research (e.g. universities) * must provide value

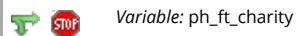

A national charity doing research (e.g MIND, Cancer Research UK, British Heart Foundation) * must provide value

\section{$\overrightarrow{2}$ Gor Variable: ph_ft_profit_tx}

A profit-making company doing research into treatments (e.g. pharmaceutical company, health technology company) * must provide value 


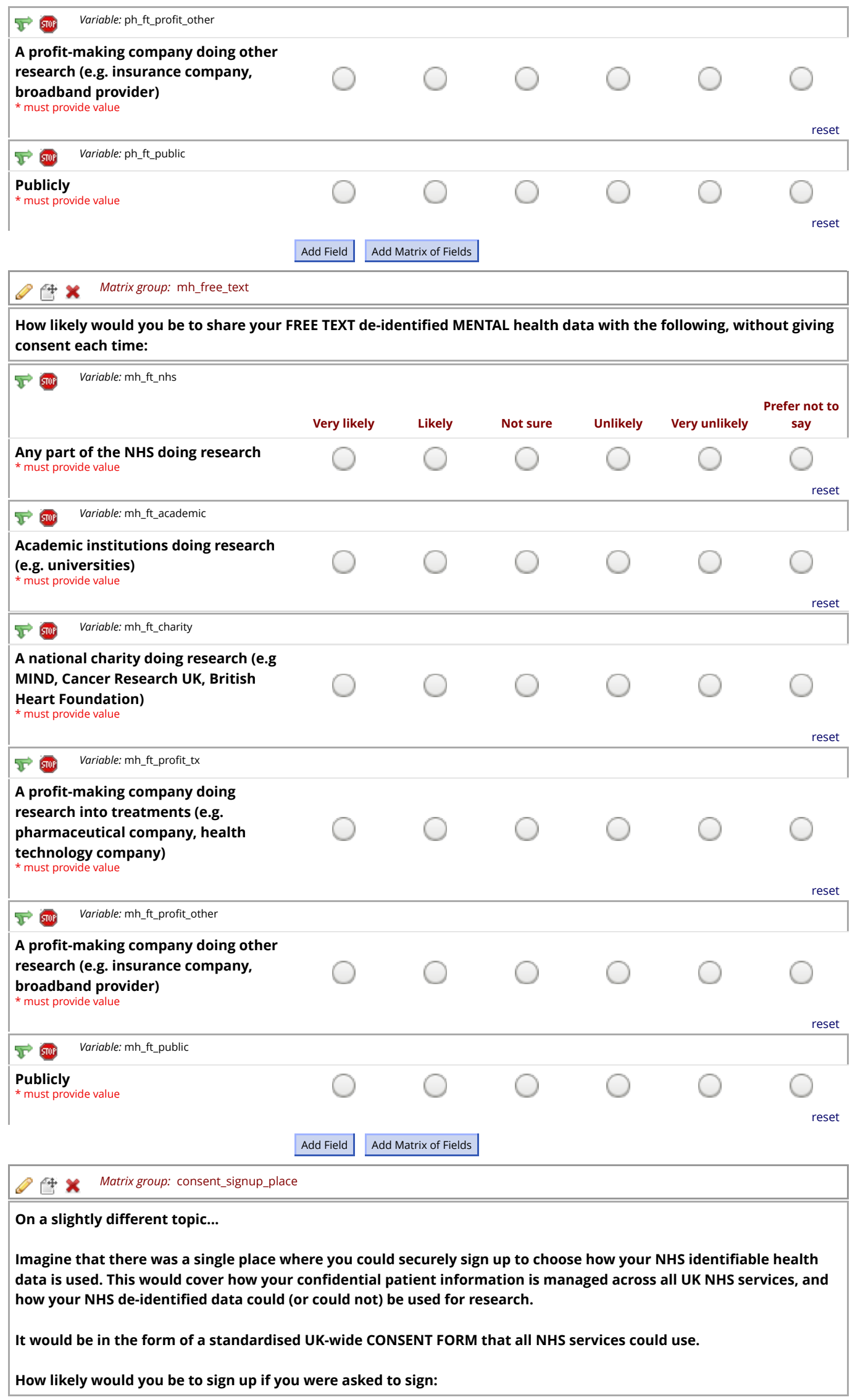




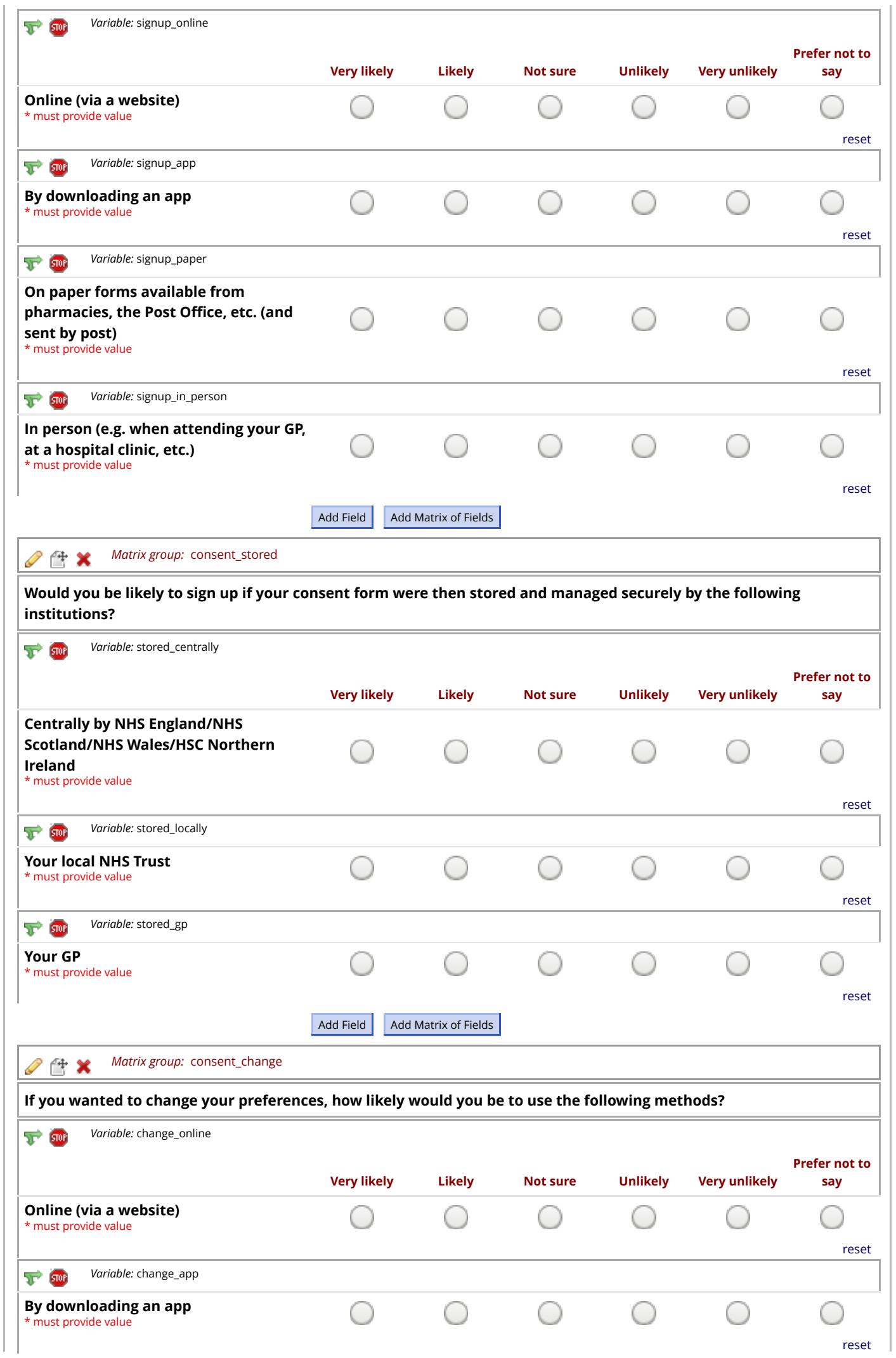




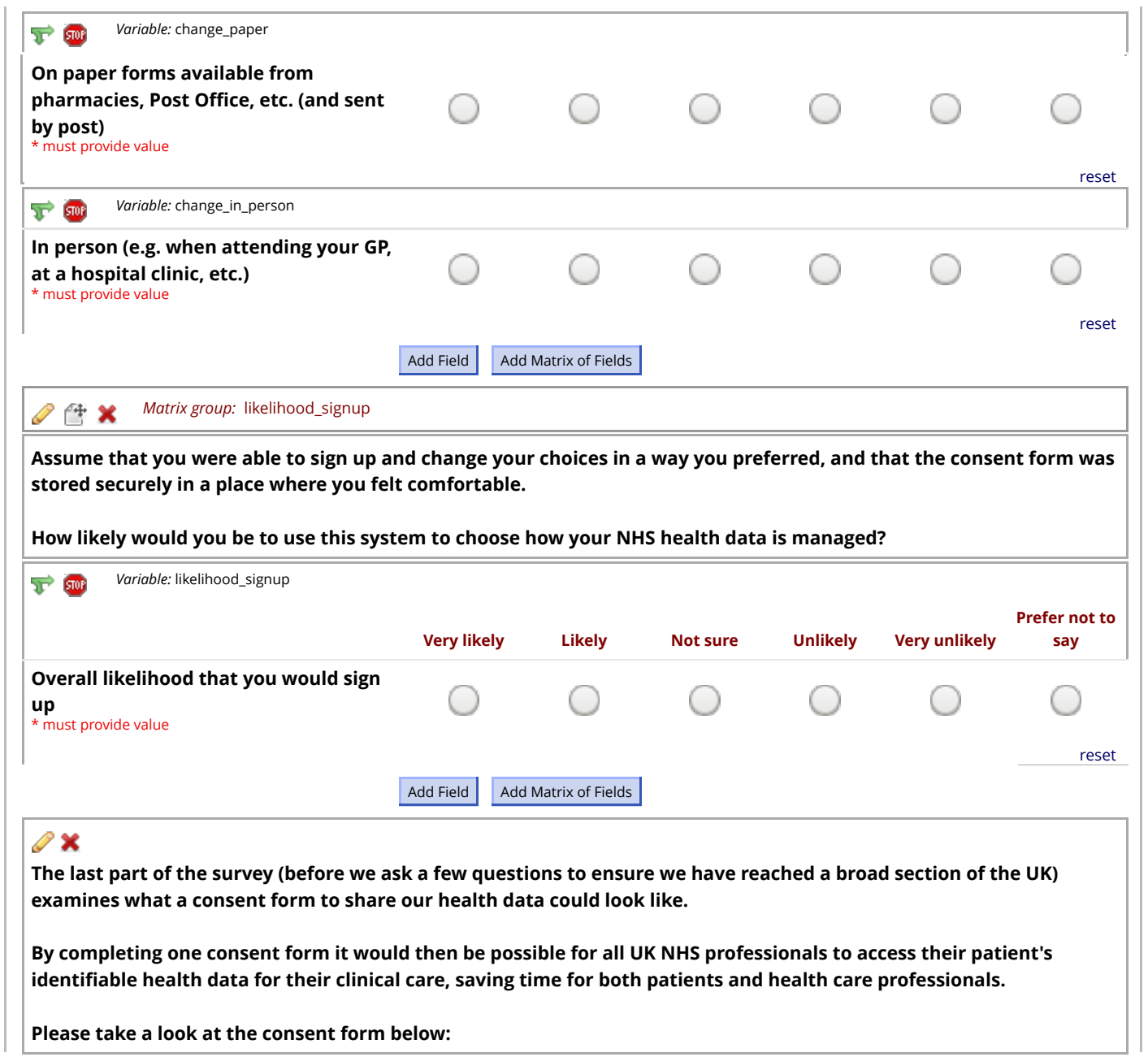


National NHS/HSC data sharing consent form HSC), Health and Social Care

Full name Date of birth NHS number Address

E-mail address

I confirm I have read the information sheet 'Sharing My Health Data' version XXX dated XXX. I have had the opportunity to consider the information and ask questions. I understand that my participation is voluntary, and that $I$ am free to change or withdraw my consent at any time, without giving a reason and without my medical care or rights being affected.

\section{Providing health care to you}

Confidential patient information is information that can identify you and that says something about your health care or treatment. Information about you might be held by several NHS organizations (such as GP surgeries and hospitals). May they share your information with each other when providing health care to you?

I agree that all NHS care providers and professionals may share my confidential patient information with each other for the purpose of my treatment and care.

\section{Using your de-identified data to help others}

The NHS promises to anonymise the information collected during the course of your treatment and use it to support research and improve care for others. Research is conducted by the NHS and by NHS-approved researchers in organizations such as universities. Strict security controls apply to the use of NHS data, even after information that might identify you (such as names and addresses) has been removed. All research involving NHS data must be approved by the NHS.

Saying no doesn't prevent all uses of your confidential information for research. To do that, use the national data opt-out at https://www.nhs.uk/your-nhs-data-matters.

I agree that all NHS care providers may share my confidential patient $\quad$ Yes [ ] No [ ] information with each other and de-identify it for the purpose of research.

\section{Taking part in research}

Some research involves direct participation. This ranges from questionnaires to trials of new treatments. The NHS promises to inform you of research studies in which you may be eligible to participate. There is never a commitment to take part.

I agree that NHS-approved researchers may learn my identity and contact me Yes [ ] No [ ] directly about research studies for which I may be eligible.

Signature:

Date:

4. Matrix group: consent_form

Having looked at the consent form, please agree or disagree with the following statements.

(If you would like to take another look at the consent form at any time while answering this question, you can use the 'previous' button at the bottom of this page to look back. This will not affect answers already given.) 


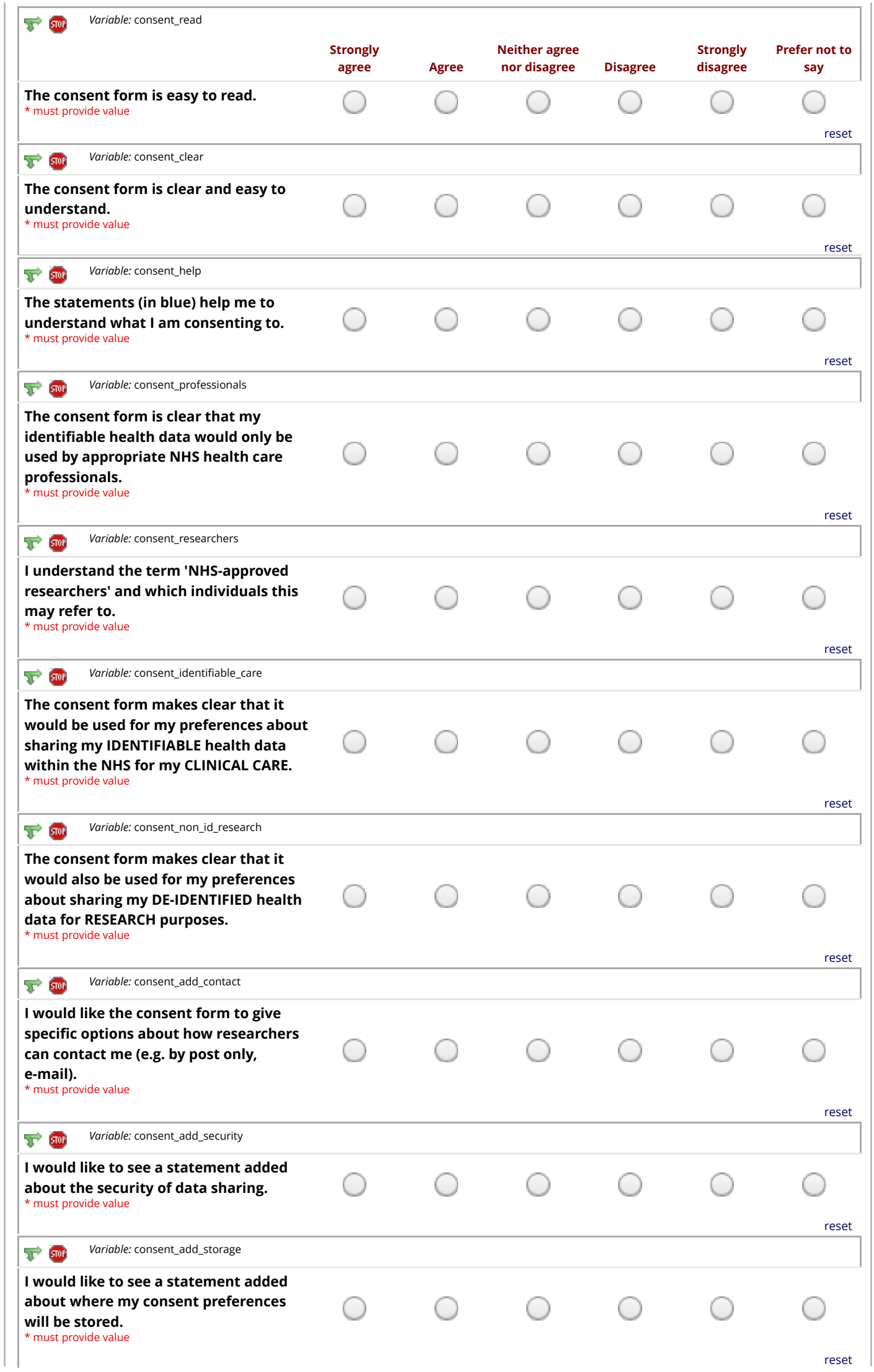




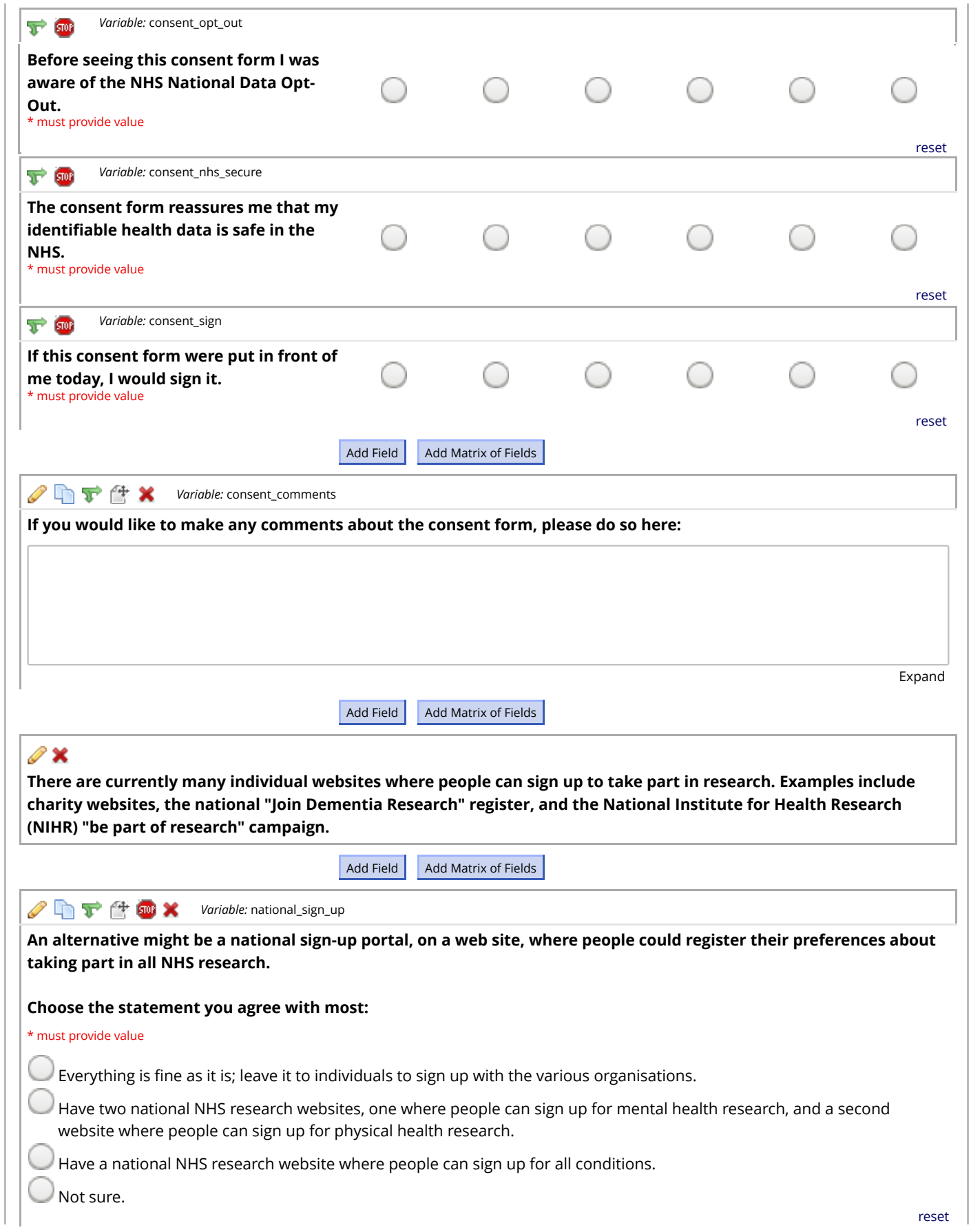


\% $\times$ Matrixgroup: linked_data

Finally, it can be very valuable for research to link health (NHS) data to other data sources.

For example, causes of death (from death certificates) are held by the UK Office of National Statistics (ONS), rather than the NHS -- so to find out more about the reasons people die, NHS and ONS data must be linked.

Usually, this is done as follows:

a) Research teams seek special permission for the process.

b) The relevant information from each organization, plus a small amount of identifiable information, is given to a "trusted third party" (e.g. an NHS Trust, the Office of National Statistics).

c) The trusted third party links the information, then removes any details that can identify anyone.

d) Researchers are then given access to the de-identified information only, under special controls.

We are interested to hear whether you would be happy for your health data to be linked, in this way, to:

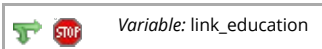

Yes

Not sure

No

Prefer not to say

Educational data (e.g. to study impact of

illness on education)

* must provide value

$\vec{V}$ Givi Variable: link_police

Police/Criminal Justice data (e.g. to

study health in the victims of crime)

* must provide value

$\overrightarrow{2}$ Gำ Variable: link_transport

Transport/DVLA data (e.g. to study

health and pollution)

* must provide value

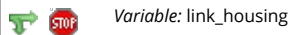

Housing data (e.g. impact of social

housing on health)

* must provide value

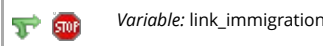

Immigration data (e.g. health in

immigrants)

* must provide value

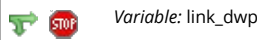

Social security/Work and Pensions (e.g.

health and financial insecurity)

* must provide value

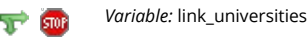

Data held about you for research by

universities (e.g. if you have

volunteered for research studies)

* must provide value

$\overrightarrow{5}$ ज़ㅏ. Variable: link_private

Data held about you by private

companies

* must provide value 


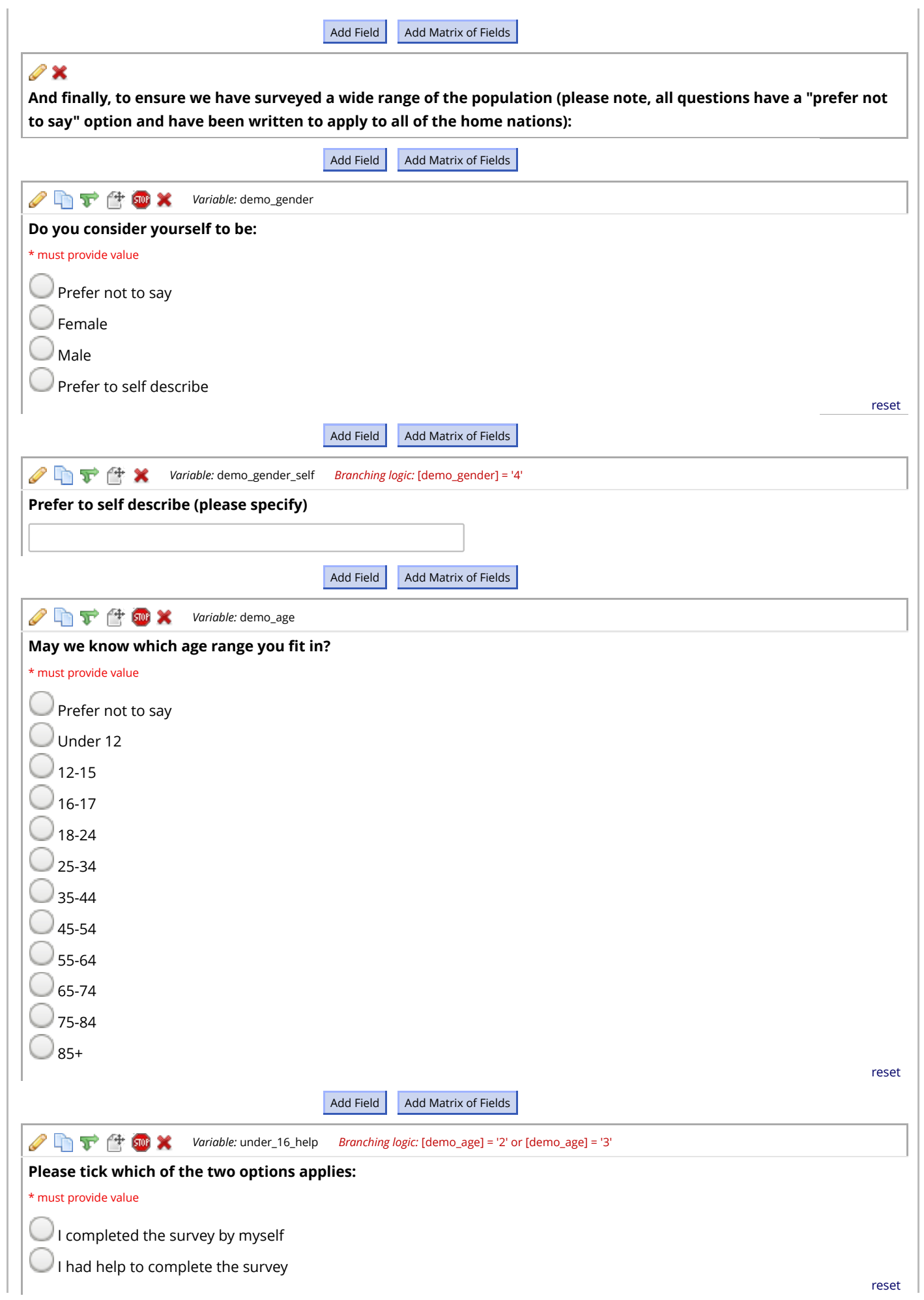


(2) $\vec{x}$ जariable: demo_ethnicity

What do you consider your ethnicity to be?

* must provide value

Prefer not to say

White

Irish Traveller

Mixed/Multiple ethnic groups

Asian or Asian British

Indian

Pakistani

Bangladeshi

Chinese

Black/African/Caribbean/Black British

Arab

Other or prefer to self describe

Add Field Add Matrix of Fields

reset

(2) $\overrightarrow{2} \boldsymbol{*}$ Variable: demo_ethnicity_other Branching logic: [demo_ethnicity] = '12'

Other or prefer to self describe (please specify)

Add Field Add Matrix of Fields

(2) $\Rightarrow$ जariable: demo_education

What is the highest qualification you have achieved?

* must provide value

Prefer not to say

No formal qualifications

Secondary school level qualifications e.g. CSE, GCSE, O-Levels, Nationals, or equivalent

A-Levels, Highers, or equivalent

Vocational qualification or equivalent

Undergraduate degree or equivalent

Postgraduate or professional qualification or equivalent

Add Field Add Matrix of Fields

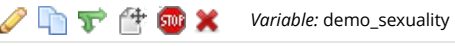

Do you consider yourself to be

* must provide value

Prefer not to say

Heterosexual (straight)

Homosexual (gay or lesbian)

Bisexual

Other or prefer to self describe 


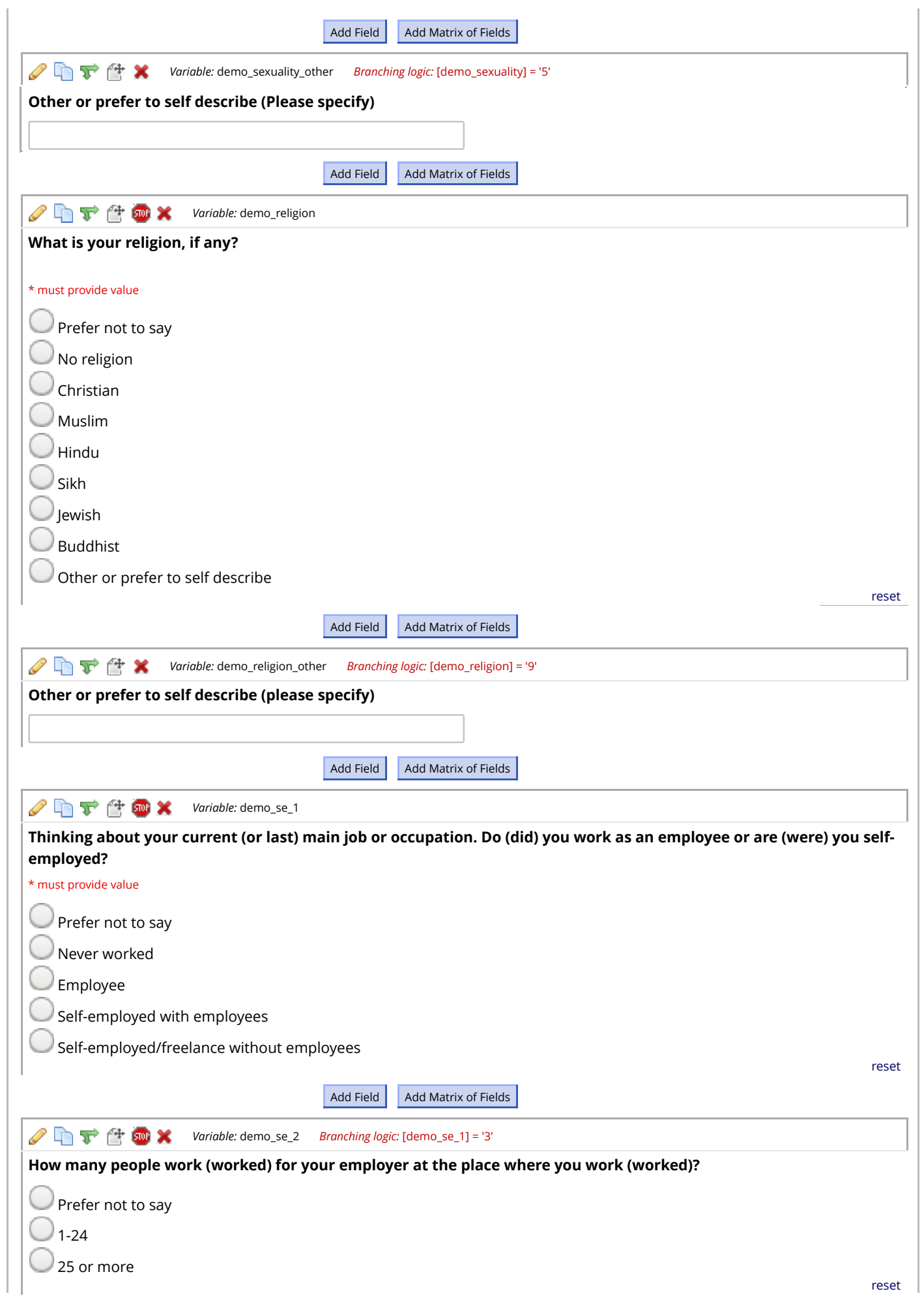




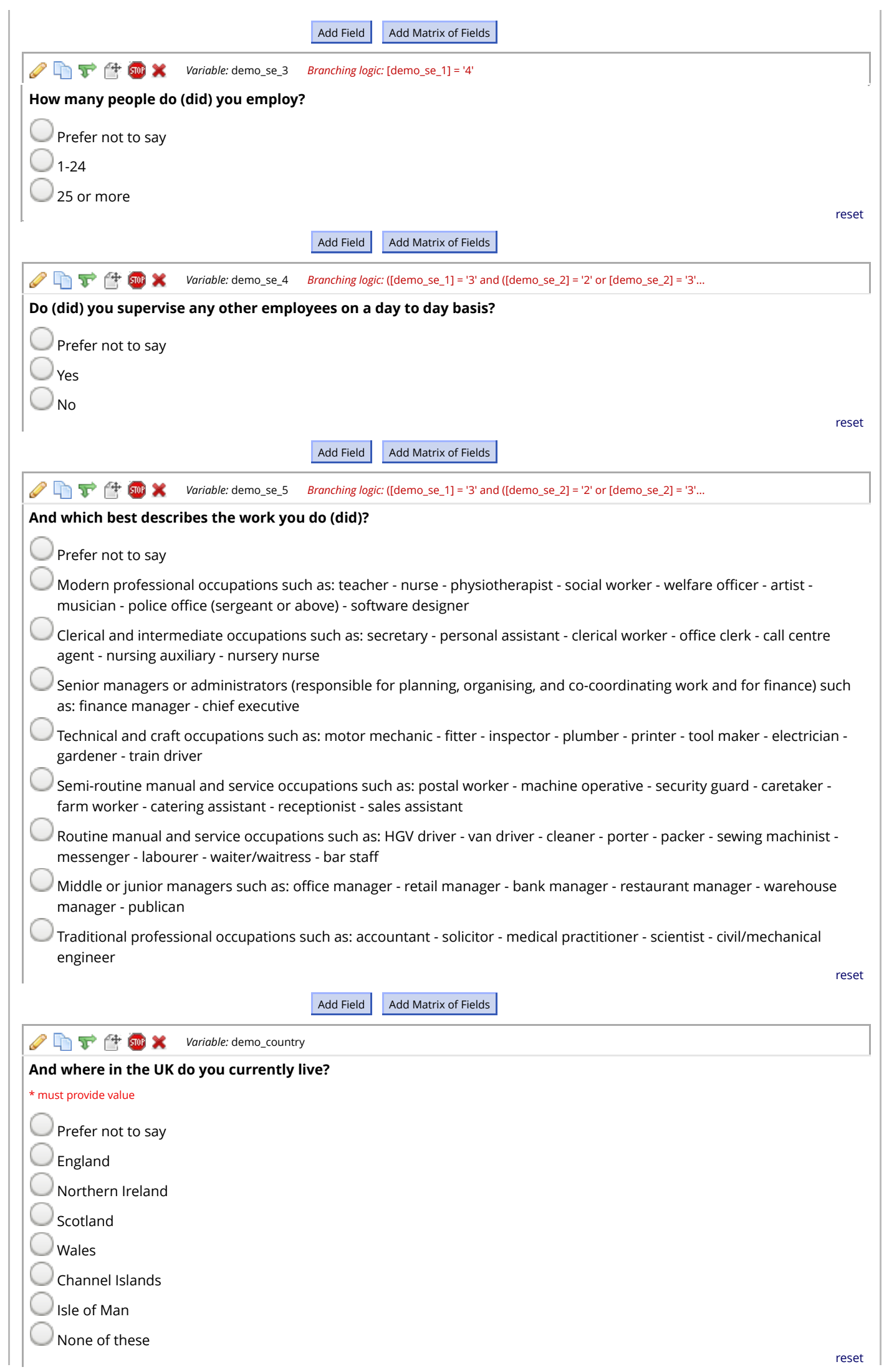




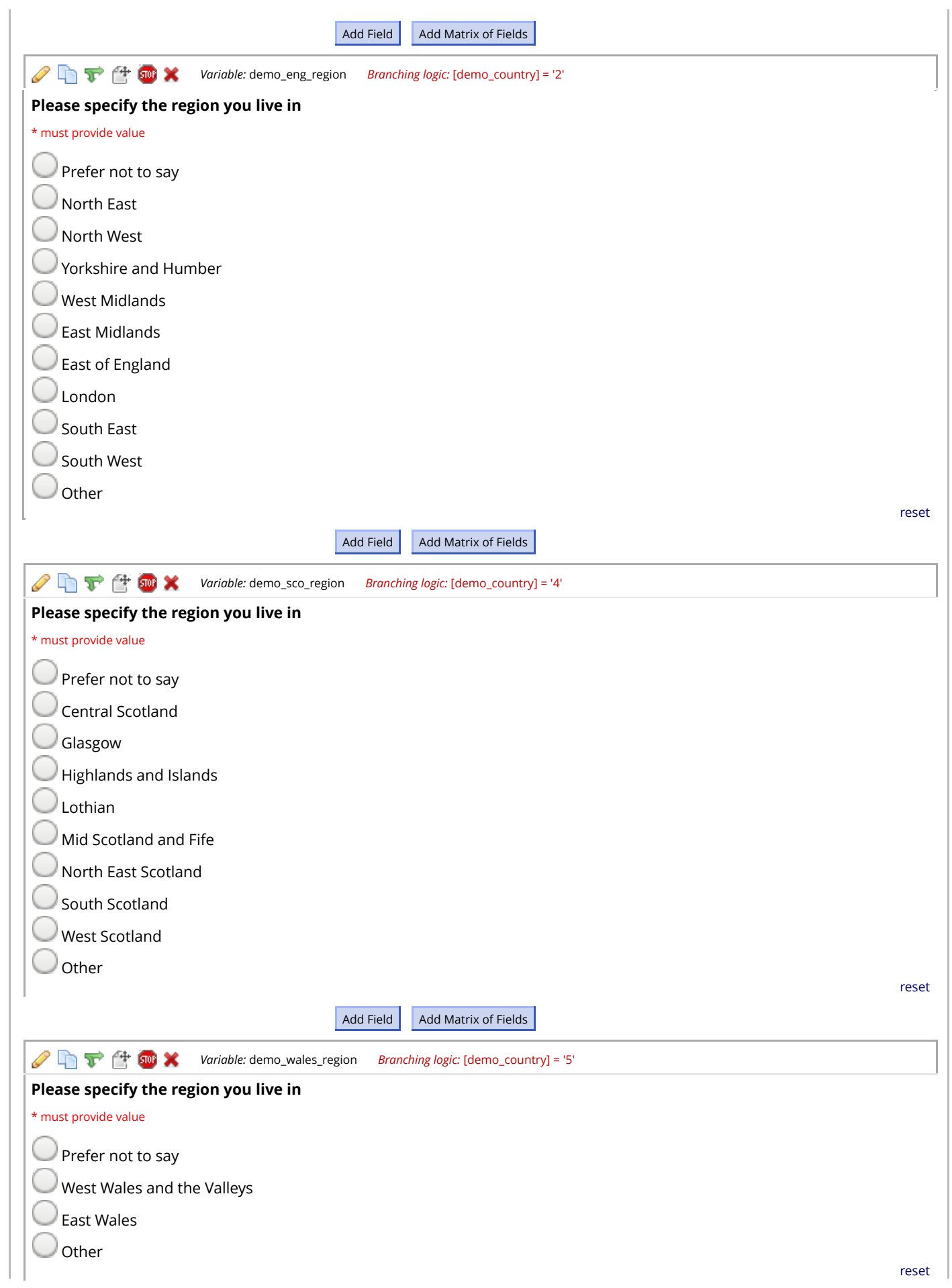




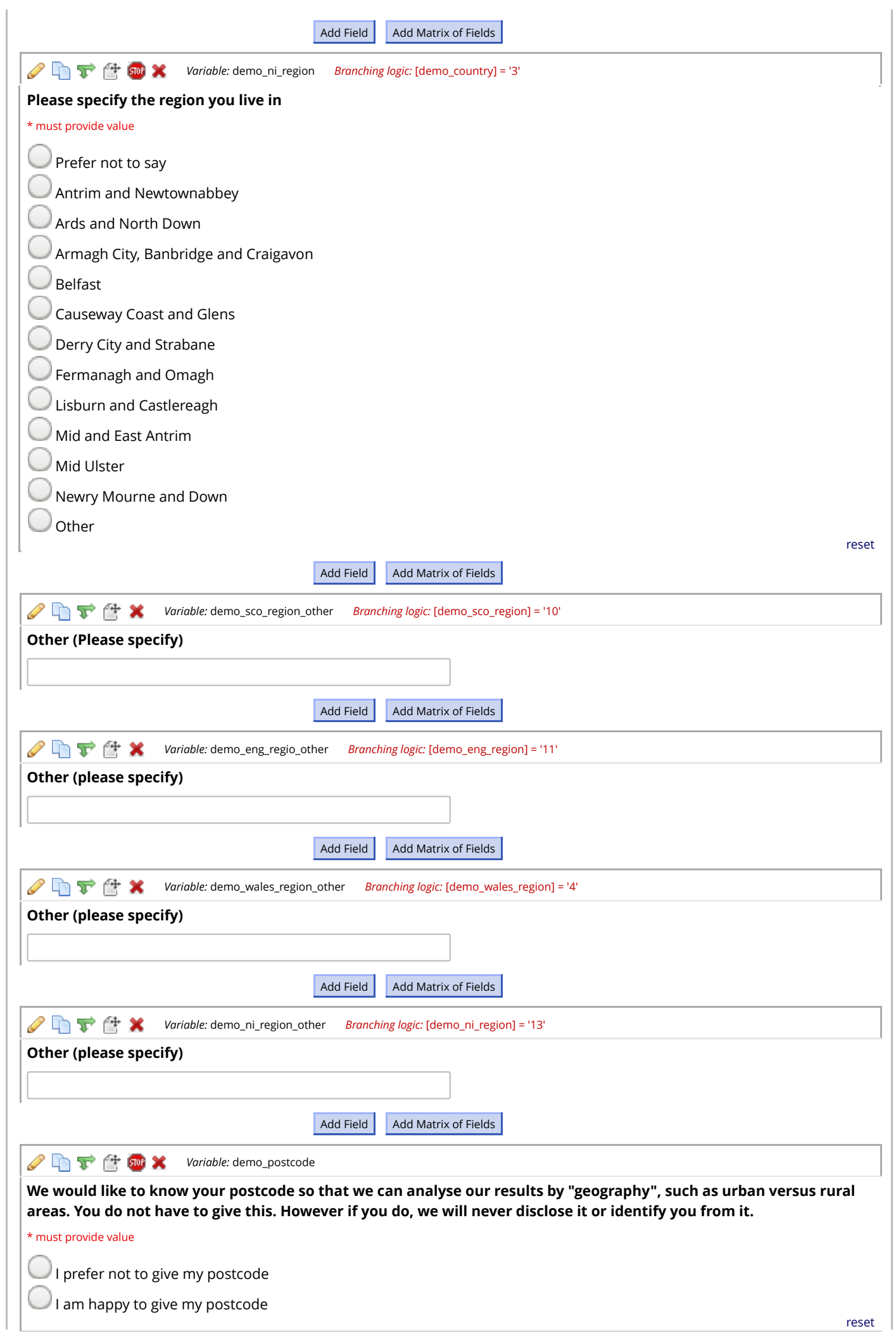




\begin{tabular}{|c|c|c|}
\hline & Add Field & Add Matrix of Fields \\
\hline \multirow[t]{2}{*}{$\begin{array}{l}\text { Postcode } \\
\text { Po }\end{array}$} & \multicolumn{2}{|c|}{ ual Branching logic: [demo_postco } \\
\hline & \multicolumn{2}{|c|}{ Add Field Add Matrix of Fields } \\
\hline$\theta \square \overrightarrow{0}$ & \multicolumn{2}{|c|}{ Variable: email } \\
\hline \multicolumn{3}{|c|}{$\begin{array}{l}\text { Before you submit your answers there is the option to leave an e-mail address should you wish to have the final } \\
\text { report of the survey results personally e-mailed to you. }\end{array}$} \\
\hline \multicolumn{3}{|c|}{$\begin{array}{l}\text { Please note: all e-mail addresses will be removed from the survey answers so that you cannot be identified, and will } \\
\text { be held securely on password-protected computers at the University of Cambridge until the results are available, as } \\
\text { described in the information sheet at the start of the survey. }\end{array}$} \\
\hline \multirow{2}{*}{\multicolumn{3}{|c|}{$\begin{array}{l}\text { If you wish to leave an e-mail address, please do so in the box belov } \\
\text { please submit your answers now. }\end{array}$}} \\
\hline & & \\
\hline 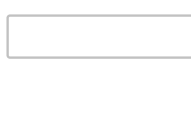 & Add Field & Add Matrix of Fields \\
\hline
\end{tabular}


medRxiv preprint doi: https://doi.org/10.1101/2021.07.19.21260635; this version posted July 19, 2021. The copyright holder for this preprint

(which was not certified by peer review) is the author/funder, who has granted medRxiv a license to display the preprint in perpetuity. It is made available under a CC-BY 4.0 International license .

\section{NHS Data Consent Survey}

\section{What am I being invited to do?}

You are being invited to take part in an online survey about the UK's views on sharing National Health Service (NHS) (or Health and Social Care in Northern Ireland) health data, for both clinical and research purposes. This survey is open to anyone living in the UK over 16 years of age (or under 16 with parental permission). If you are under 16, please show your parent/guardian this page and ask if they are happy for you to take this survey. You will need to confirm you have their permission before you start the survey.

\section{What will taking part involve?}

If you agree to take part, after filling in a consent form, you will be asked a series of questions about your views on sharing your NHS/HSC health data for both clinical and research purposes. By 'health data' we mean any information collected about a person's health including things like medical notes, blood test results, prescription information etc. collected by an appropriate health care professional. As well as asking about sharing health data, we will also ask you some questions about your physical and mental health and any health services you may have used, as well as some questions about you, for example your age and gender. The survey does not ask for any identifiable personal information, and at any time you may click the "prefer not to answer" box if you wish.

The survey has been tested and will take approximately 18-25 minutes to complete. The survey does not need to be completed at one sitting.

Your answers won't affect the way your own health information is managed.

\section{What are the benefits or disadvantages of taking part in the survey?}

There are no direct benefits or disadvantages to taking part in this survey nor are there any payments. However, the study team hopes the results of this survey can be used to inform and improve the way the NHS/HSC manage data for clinical and research purposes.

\section{Do I have to take part?}

No, taking part in this survey is entirely up to you. The consent form at the start of the survey asks for your permission to use your data, even if you decide not to complete all of the survey. Unfortunately, once data has been submitted it will not be possible for the study team to find and delete your answers as we are not asking for any personal details, making it impossible for us to retrieve and delete your individual answers.

\section{How will the information I give be kept confidential? Where can I find out more about how your information is used?}

No information that can identify you is being collected in this study. There is an option to leave an email address, should you wish to personally receive the results of the survey. Email addresses will be removed from the survey responses and stored on password protected computers at the University of Cambridge. Access to these email addresses will be by the study team only and will only be used to send you the final results of the survey. Once you have received the results you will be asked if you would like any further updates, for example any publications or posters that arise from the results of the study. If you decide you do not want any further information, we will delete your email address. If you would like further updates, we will keep your email address securely until we have sent you the final publications from the study, at which time point your email address will then be deleted from our records.

There is also an option to leave your postcode (or not) in the survey. The study team would like to look at whether there are any effects of geographical area on answers to the survey. Once the survey has closed the study team will convert all postcodes to a nationally available 'code' of the area you live in, and then delete your postcode. By doing this it will never be possible to identify you or the road that you live in, as one code is given to multiple postcodes in the same area. Whether or not you agree to give us your post code is entirely up to you.

Once the study team have finished using the de-identified data, they will make it freely available for public use via the University of Cambridge Research Data Repository (https://www.data.cam.ac.uk/repository). Please be assured that, as in the information above, any email addresses or postcodes given will have been deleted before this happens. There will be no way that anyone will be able to identify you from the data, but we hope that others may use the data to further understand the sharing of health data with the aim to improve mental and physical health.

You can find out more about how we use your information:

- at www.hra.nhs.uk/information-about-patients

- our leaflet from http://www.hra.nhs.uk/patientdataandresearch

- by sending an email to the University of Cambridge Data Protection officer at dpo@ @admin.cam.ac.uk

- by asking one of the research team

\section{Who is conducting this survey?}

This survey is being conducted by the CLIMB project study team based at the University of Cambridge in conjunction with a patient and public research advisory group. Funding for the study team is from the Medical Research Council's (MRC) Mental Health Data Pathfinder awards. 
medRxiv preprint doi: https://doi.org/10.1101/2021.07.19.21260635; this version posted July 19, 2021. The copyright holder for this preprint (which was not certified by peer review) is the author/funder, who has granted medRxiv a license to display the preprint in perpetuity.

It is made available under a CC-BY 4.0 International license .

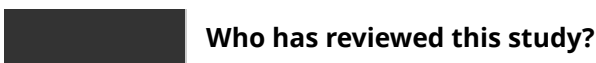

This study has been reviewed and given a favourable opinion by members of the East of Scotland Research Ethics Service.

\section{Where can I find the results of this survey?}

Once the study has concluded and the results have been analysed, a report will be made available. If you have chosen to leave an email address this report will be sent directly to you. Results will also be published on the following websites: https://www.climbproject.org.uk/ and www.psychiatry.cam.ac.uk. You may like to note these down now before you move on or, alternatively, they will be displayed again at the end of the survey.

\section{What if I have any concerns about this study?}

The study team can be contacted in the following ways:

Mrs Linda Jones

Email: lajj요cam.ac.uk

Telephone (01223) 764670

Further contact details are available at: https://www.climbproject.org.uk/

Alternatively you may like to contact the CPFT's Patient Advice and Liaison Service (PALS) on 08003760775 or email pals@cpft.nhs.uk. Please note PALS will not be able to give advice about technical queries with the study.

Thank you very much for reading the information sheet about the survey. If you would now like to take part in the survey, please read the following statements and tick the boxes to show that you agree. Please only take the survey one time (although you do not have to complete it in one go).

Page 1 of 29 
medRxiv preprint doi: https://doi.org/10.1101/2021.07.19.21260635; this version posted July 19, 2021. The copyright holder for this preprint (which was not certified by peer review) is the author/funder, who has granted medRxiv a license to display the preprint in perpetuity.

It is made available under a CC-BY 4.0 International license .

\section{NHS Data Consent Survey}

Page 2 of 29

Consent Form

I confirm I am aged 16 or over, or I am under 16 years of age but have the consent of my parent/guardian.

* must provide value

I confirm that I am a resident of the UK.

must provide value

I understand I may quit the survey at any time but any data I have

provided may still be used. * must provide value

I understand that the answers I give will be used for analysis and

publication.

* must provide value

I understand my answers will be recorded in a way that means I cannot be identified.

* must provide value

I understand that not everyone will see the same questions or

definitions.

* must provide value

If I have any problems or questions with the survey, I understand I can contact Linda Jones, e-mail:

laj28@cam.ac.uk, telephone: 01223

764670

* must provide value

If I choose to leave an email address, I understand it will be removed from the survey and only used to send me the results of the survey * must provide value

Please tick ALL boxes

I consent to take part in this survey.

* must provide value

We would like to know where you heard about this survey. It is especially important to know if you were given a leaflet (or letter) or saw a poster/text/social media from a 'healthcare provider' e.g. hospital, clinic, GP, ambulance service, healthcare community setting, or any other healthcare provider.

* must provide value

Prefer not to say

GP (via a poster, leaflet, from a staff member, via text, via GP Practice social media etc.)

- Hospital/Clinic/Ambulance/Healthcare community setting, other healthcare provider (via a poster, leaflet, from a staff member, text, healthcare provider's social media etc.)

Group to which I belong

Charity website/email/newsletter etc.

Social media (other than from a healthcare provider)

Poster (other than at a healthcare provider)

Browsing the internet

Friend

Not sure

Other 
medRxiv preprint doi: https://doi.org/10.1101/2021.07.19.21260635; this version posted July 19, 2021. The copyright holder for this preprint (which was not certified by peer review) is the author/funder, who has granted medRxiv a license to display the preprint in perpetuity.

It is made available under a CC-BY 4.0 International license .

Please could you tell us in which healthcare establishment you saw a poster or picked up/were given a leaflet? If you have the leaflet, the healthcare setting may be named on the back of it. This is really important to each healthcare provider. (Please type in a few letters and options will appear.)

* must provide value

Cambridgeshire and Peterborough NHS Foundation Trust (CPFT)

$\ll$ Previous Page

Next Page $>>$ 
medRxiv preprint doi: https://doi.org/10.1101/2021.07.19.21260635; this version posted July 19, 2021. The copyright holder for this preprint (which was not certified by peer review) is the author/funder, who has granted medRxiv a license to display the preprint in perpetuity. It is made available under a CC-BY 4.0 International license .

\section{NHS Data Consent Survey}

Before starting the survey please read the following definitions:

By "NHS" we mean all parts of the national health service in the UK: NHS England, NHS Scotland, NHS Wales, and Health and Social Care in Northern Ireland (HSC). We refer to all these as the NHS in this survey.

Health data means any information about a person's health such as might be collected by a nurse, doctor or other appropriate member of NHS staff. Health data includes things like your medical notes, blood test results, prescription information, scans, etc.

Identifiable health data means any health data (as described above) that can also identify a person -- such as any health data that also contains names, addresses, NHS numbers, etc.

Clinical care means providing health care directly to people -- for example, diagnosing illnesses or treating ill health.

We would like to know/gauge your understanding of how NHS clinical care providers currently share your identifiable health data for your clinical care, without asking you each time. If you are not sure, please have a "best guess" as to what you think might happen.

My understanding is that (please tick only one):

* must provide value

My identifiable health data is currently shared freely between all NHS sites across the UK -- i.e. all acute hospital Trusts, my GP, all mental health Trusts, ambulance services, etc., in the whole UK.

My identifiable health data is currently shared between all NHS sites but only in the home nation that I live in -- i.e. shared only in England, or Scotland, or Northern Ireland, or Wales, but not between them.

My identifiable health data is currently only shared between NHS sites in my region (cluster of hospitals nearest to my local hospital).

My identifiable health data is currently only shared between my GP, acute local hospital, local mental health Trust, and other local services.

My identifiable health data is currently not shared between any NHS sites.

\begin{tabular}{c|}
\hline < Previous Page \\
\hline Next Page $\gg>$ \\
\hline
\end{tabular}


medRxiv preprint doi: https://doi.org/10.1101/2021.07.19.21260635; this version posted July 19, 2021. The copyright holder for this preprint (which was not certified by peer review) is the author/funder, who has granted medRxiv a license to display the preprint in perpetuity.

It is made available under a CC-BY 4.0 International license.

\section{NHS Data Consent Survey}

Page 4 of 29

MOST hospital Trusts, GPs, mental health Trusts are separate and currently DO NOT share identifiable health data without asking you, though they correspond and communicate with each other with your permission.

In view of the statement above, we would now like to ask you your views on sharing your own identifiable health data for YOUR CLINICAL CARE, without having to be asked each time (please tick only one):

* must provide value

I would like my identifiable health data to be shared for clinical purposes with any part of the NHS in the UK, without asking me first.

I would like my identifiable health data to be shared for clinical purposes with any part of the NHS in my home nation only (i.e. only in England, or only in Northern Ireland, or only in Scotland, or only in Wales) without asking me first.

I would like my identifiable health data to be shared for clinical purposes with any part of my region (cluster of hospitals nearest to my local hospital), without asking me first.

I would like my identifiable health data to be shared for clinical purposes only with my GP, local hospital, and local mental health services, without asking me first.

No one in the NHS should share my identifiable health data without asking me first.

Not sure. 
medRxiv preprint doi: https://doi.org/10.1101/2021.07.19.21260635; this version posted July 19, 2021. The copyright holder for this preprint (which was not certified by peer review) is the author/funder, who has granted medRxiv a license to display the preprint in perpetuity.

It is made available under a CC-BY 4.0 International license.

\section{NHS Data Consent Survey}

We would now like to ask you some questions about your own MENTAL and PHYSICAL health. You can "prefer not to say" if you wish.

We would like to ask if you have had a MENTAL health condition either recently or at some point in your life.

By mental health conditions we include things like delirium, self harm, substance abuse, dementia, mania, schizophrenia, depression, anxiety disorders, psychosis, eating disorders, OCD, personality disorders, etc.

* must provide value

I prefer not to say.

Yes, I have had a mental health condition either recently or at some point in my life.

No, I have never had a mental health condition.

$\ll$ Previous Page

Next Page $\gg$ 
medRxiv preprint doi: https://doi.org/10.1101/2021.07.19.21260635; this version posted July 19, 2021. The copyright holder for this preprint (which was not certified by peer review) is the author/funder, who has granted medRxiv a license to display the preprint in perpetuity.

It is made available under a CC-BY 4.0 International license.

\section{NHS Data Consent Survey}

Page 6 of 29

We would like to know if you would be willing to share what mental health condition you have had.

You may tick as many boxes as you wish.

If you prefer not to say, please use the "next page" button below to move on.

In the last 5 years

More than 5 years ago

\section{Delirium}

Alcohol or substance abuse

Schizophrenia, schizoaffective

disorder, or delusional disorder

\section{Dementia}

Mania or bipolar affective disorder

Depression

Anxiety disorder (e.g. phobia, panic, generalized anxiety disorder, posttraumatic stress disorder)

Psychosis of any cause

\section{Eating disorder (e.g. anorexia} nervosa, bulimia)

Obsessive-compulsive disorder

Personality disorder

Self harm

Other

« Previous Page

Next Page $>>$ 
medRxiv preprint doi: https://doi.org/10.1101/2021.07.19.21260635; this version posted July 19, 2021. The copyright holder for this preprint (which was not certified by peer review) is the author/funder, who has granted medRxiv a license to display the preprint in perpetuity.

It is made available under a CC-BY 4.0 International license

\section{NHS Data Consent Survey}

Page 7 of 29

And also in relation to mental health:

We would also like to know if you have accessed any mental health services for your own mental health condition.

These might include your GP, online services, mental health forums, psychological therapy services, crisis care, home treatments or visits, outpatient or inpatient care, services from the private sector, support from a mental health charity, etc.

* must provide value

I prefer not to say.

- I have used mental health services.

I have not used any mental health services (not even my GP or surgery) for my mental health condition.

Mental health support from your GP

or surgery

An NHS psychological therapy service,

e.g. IAPT or other therapy service

(INDIVIDUAL session)

An NHS psychological therapy service,

e.g. IAPT or other therapy service

(GROUP session)

An NHS psychological therapy service,

e.g. IAPT or other therapy service

(ONLINE)

NHS outpatient or community mental

health services, or key worker

NHS crisis care/Home Treatment

teams

NHS inpatient mental health services

in a mental health hospital

NHS inpatient mental health services

in a general hospital (liaison

psychiatry)

Private services

Services in the workplace e.g.

Occupational Health

Charity providing mental health

support

Online forum

Other

$\ll$ Previous Page

Next Page $>$

Save \& Return Later 
medRxiv preprint doi: https://doi.org/10.1101/2021.07.19.21260635; this version posted July 19, 2021. The copyright holder for this preprint (which was not certified by peer review) is the author/funder, who has granted medRxiv a license to display the preprint in perpetuity.

It is made available under a CC-BY 4.0 International license.

\section{NHS Data Consent Survey}

We are also interested to know if you have accessed any services regarding your own PHYSICAL health.

This could be services like your GP, outpatient hospital appointments, inpatient services, online support, Accident and Emergency, 111 service, private services, charities providing physical health support, etc.

Have you ever used any of the following services for your own PHYSICAL health?

* must provide value

I prefer not to say

- I have used physical health services (this includes using your GP)

I have not used any physical health services

$<$ Previous Page

Next Page $>$ 
medRxiv preprint doi: https://doi.org/10.1101/2021.07.19.21260635; this version posted July 19, 2021. The copyright holder for this preprint (which was not certified by peer review) is the author/funder, who has granted medRxiv a license to display the preprint in perpetuity.

It is made available under a CC-BY 4.0 International license.

\section{NHS Data Consent Survey}

Page 9 of 29

And finally in this section, we would like to know if you would be willing to share what physical health services you have used for your own physical health.

You may tick as many boxes as you wish.

Please use the 'next page' button if you prefer not to answer.

More than 5 years ago

Physical health support from your GP or surgery

NHS hospital outpatient services

(outpatient clinics etc.)

NHS Urgent Care Centre (not A\&E) or NHS 111 helpline

NHS Accident and Emergency services (A\&E)

NHS inpatient services (procedures not completed in 1 day)

NHS Day Surgery/day care in a

hospital

Private services

Services in the workplace e.g.

Occupational Health

Charity providing physical health

support

Online forum

Other

< Previous Page

Next Page $>>$ 
medRxiv preprint doi: https://doi.org/10.1101/2021.07.19.21260635; this version posted July 19, 2021. The copyright holder for this preprint (which was not certified by peer review) is the author/funder, who has granted medRxiv a license to display the preprint in perpetuity.

It is made available under a CC-BY 4.0 International license.

NHS Data Consent Survey

Page 10 of 29

Moving on...

The table below shows what NHS identifiable health data may look like. This sort of data is used for health care by NHS staff. (Please note the examples shown are not real.)

\begin{tabular}{|c|c|c|c|c|c|c|c|}
\hline NHS number & Title & Forename & Surname & Date of birth & Address & Diagnoses & Notes \\
\hline 9876543210 & $\mathrm{Mr}$ & John & Smith & 20 Jan 1950 & $\begin{array}{l}1 \text { The Street, } \\
\text { Maidstone }\end{array}$ & $\begin{array}{l}\text { pneumonia } \\
\text { high blood } \\
\text { pressure }\end{array}$ & $\begin{array}{l}1 \text { Apr } 2019 . \text { Seen in } \\
\text { clinic. Mr Smith has a } \\
\text { fever and a cough. His } \\
\text { chest sounds crackly. I } \\
\text { think he has } \\
\text { pneumonia. Sent to } \\
\text { hospital. }\end{array}$ \\
\hline 8765432109 & Miss & Alice & Jones & 16 Jun 1994 & $\begin{array}{l}15 \text { The Road, } \\
\text { Dundee }\end{array}$ & $\begin{array}{l}\text { depression } \\
\text { carpal tunnel } \\
\text { syndrome }\end{array}$ & $\begin{array}{l}2 \text { Apr } 2019 . \text { Alice rates } \\
\text { her mood as } 1 / 10 \text { on } \\
\text { average, she is more } \\
\text { tired, and she is not } \\
\text { looking forward to } \\
\text { anything. Her } \\
\text { depression has } \\
\text { worsened. She wishes } \\
\text { to restart citalopram. }\end{array}$ \\
\hline 7654321098 & Mrs & Chloe & Williams & 4 May 1930 & $\begin{array}{l}5 \text { Tree Close, } \\
\text { Cardiff }\end{array}$ & $\begin{array}{l}\text { broken } \\
\text { humerus } \\
\text { anxiety }\end{array}$ & $\begin{array}{l}3 \text { Apr } 2019 . \text { Chloe fell } \\
\text { after skidding on an } \\
\text { oily patch while cycling } \\
\text { and was hit by a car. } \\
\text { Has an obvious fracture } \\
\text { of her left upper arm. } \\
\text { Needs X-ray. }\end{array}$ \\
\hline 6543210987 & Mr & Pradeep & Agarwal & 22 Sep 1973 & $\begin{array}{l}27 \text { The } \\
\text { Mews, } \\
\text { London }\end{array}$ & $\begin{array}{l}\text { schizophrenia } \\
\text { diabetes }\end{array}$ & $\begin{array}{l}4 \text { Apr 2019. Pradeep stil } \\
\text { worries that other } \\
\text { people can hear his } \\
\text { thoughts, but this is } \\
\text { getting less common. } \\
\text { He is attending } \\
\text { cognitive-behavioural } \\
\text { therapy sessions. }\end{array}$ \\
\hline
\end{tabular}

\begin{tabular}{|c|}
\hline Next Page $>>$ \\
\hline
\end{tabular}


medRxiv preprint doi: https://doi.org/10.1101/2021.07.19.21260635; this version posted July 19, 2021. The copyright holder for this preprint (which was not certified by peer review) is the author/funder, who has granted medRxiv a license to display the preprint in perpetuity.

It is made available under a CC-BY 4.0 International license .

\section{NHS Data Consent Survey}

Previous surveys have found that people have more concerns about the use of their identifiable health data relating to their mental health than other aspects of their physical health care.

Regardless of whether you have a PHYSICAL health condition or have used PHYSICAL health services:

How likely are you to agree to share your identifiable PHYSICAL health data for your clinical care with the following, without being asked every time?

Very likely Likely Very Prefer not

Between my local NHS services -- i.e. Very likely Likely O

unlikely to say

between my local physical and

mental health hospitals, my GP, etc.

* must provide value

Any part of the NHS in my region (cluster of hospitals nearest to my local hospital)

* must provide value

Any part of the NHS in my home nation only (i.e. only in England, or only in Northern Ireland, or only in Scotland, or only in Wales)

* must provide value

Any part of the NHS in the UK * must provide value

O

○

O

$0 \quad 0 \quad 0$


medRxiv preprint doi: https://doi.org/10.1101/2021.07.19.21260635; this version posted July 19, 2021. The copyright holder for this preprint (which was not certified by peer review) is the author/funder, who has granted medRxiv a license to display the preprint in perpetuity.

It is made available under a CC-BY 4.0 International license.

\section{NHS Data Consent Survey}

Regardless of whether you have a MENTAL health condition or have used MENTAL health services:

How likely are you to agree to share your identifiable MENTAL health data for your clinical care with the following, without being asked every time?

Between my local NHS services -- i.e.
between my local physical and
mental health hospitals, my GP, etc.
* must provide value
Any part of the NHS in my region
(cluster of hospitals nearest to my
local hospital)
* must provide value
Any part of the NHS in my home
nation only (i.e. only in England, or
only in Northern Ireland, or only in
Scotland, or only in Wales)
* must provide value
Any part of the NHS in the UK
* must provide value

$\ll$ Previous Page

Next Page $>>$ 
medRxiv preprint doi: https://doi.org/10.1101/2021.07.19.21260635; this version posted July 19, 2021. The copyright holder for this preprint (which was not certified by peer review) is the author/funder, who has granted medRxiv a license to display the preprint in perpetuity.

It is made available under a CC-BY 4.0 International license .

\section{NHS Data Consent Survey}

In the next two questions we would like to ask you about sharing your NHS data for research purposes.

Research is used to improve overall healthcare for everyone.

Firstly, please look at some of the NHS health care data that you saw previously, which has now been de-identified.

\begin{tabular}{|l|l|l|l|l|}
\hline $\begin{array}{l}\text { Research } \\
\text { ID }\end{array}$ & Age & Sex & Region & Diagnoses \\
\hline 5X62V & 69 & M & Kent & $\begin{array}{l}\text { pneumonia } \\
\text { high blood pressure }\end{array}$ \\
\hline 597PT & 24 & F & Dundee & $\begin{array}{l}\text { depression } \\
\text { carpal tunnel syndrome }\end{array}$ \\
\hline 8HG7S & 89 & F & Glamorganshire & $\begin{array}{l}\text { broken humerus } \\
\text { anxiety }\end{array}$ \\
\hline BA6A9 & 45 & M & London & $\begin{array}{l}\text { schizophrenia } \\
\text { diabetes }\end{array}$ \\
\hline
\end{tabular}

$\ll$ Previous Page

Next Page $>$ 
medRxiv preprint doi: https://doi.org/10.1101/2021.07.19.21260635; this version posted July 19, 2021. The copyright holder for this preprint (which was not certified by peer review) is the author/funder, who has granted medRxiv a license to display the preprint in perpetuity.

It is made available under a CC-BY 4.0 International license.

\section{NHS Data Consent Survey}

Page 16 of 29

How likely would you be to share your de-identified PHYSICAL health data with the following, without giving consent every time?

\begin{tabular}{|c|c|c|c|c|c|c|}
\hline & Very likely & Likely & Not sure & Unlikely & $\begin{array}{c}\text { Very } \\
\text { unlikely }\end{array}$ & $\begin{array}{l}\text { Prefer not } \\
\text { to say }\end{array}$ \\
\hline $\begin{array}{l}\text { Any part of the NHS doing research } \\
* \text { must provide value }\end{array}$ & 0 & 0 & 0 & 0 & 0 & $\bigcirc$ \\
\hline $\begin{array}{l}\text { Academic institutions doing research } \\
\text { (e.g. universities) } \\
* \text { must provide value }\end{array}$ & 0 & 0 & 0 & 0 & 0 & O \\
\hline $\begin{array}{l}\text { A national charity doing research (e.g. } \\
\text { MIND, Cancer Research UK, British } \\
\text { Heart Foundation) } \\
{ }^{*} \text { must provide value }\end{array}$ & 0 & $\bigcirc$ & 0 & 0 & 0 & 0 \\
\hline $\begin{array}{l}\text { A profit-making company doing } \\
\text { research into treatments (e.g. a } \\
\text { pharmaceutical company, health } \\
\text { technology company) } \\
\text { * must provide value }\end{array}$ & 0 & 0 & 0 & 0 & 0 & 0 \\
\hline $\begin{array}{l}\text { A profit-making company doing other } \\
\text { research (e.g. an insurance company, } \\
\text { broadband provider) } \\
\text { * must provide value }\end{array}$ & 0 & 0 & 0 & ○ & 0 & 0 \\
\hline $\begin{array}{l}\text { Publicly } \\
\text { * must provide value }\end{array}$ & 0 & $\bigcirc$ & 0 & 0 & 0 & O \\
\hline & $\ll$ Previ & s Page & & & & \\
\hline & Next & e >> & & & & \\
\hline & Save \& $R$ & rn Later & & & & \\
\hline
\end{tabular}


medRxiv preprint doi: https://doi.org/10.1101/2021.07.19.21260635; this version posted July 19, 2021. The copyright holder for this preprint (which was not certified by peer review) is the author/funder, who has granted medRxiv a license to display the preprint in perpetuity.

It is made available under a CC-BY 4.0 International license.

\section{NHS Data Consent Survey}

Page 17 of 29

How likely would you be to share your de-identified MENTAL health data with the following, without giving consent every time:

\begin{tabular}{|c|c|c|c|c|c|c|}
\hline & Very likely & Likely & Not sure & Unlikely & $\begin{array}{l}\text { Very } \\
\text { unlikely }\end{array}$ & $\begin{array}{l}\text { Prefer not } \\
\text { to say }\end{array}$ \\
\hline $\begin{array}{l}\text { Any part of the NHS doing research } \\
\text { * must provide value }\end{array}$ & 0 & 0 & 0 & 0 & 0 & reset \\
\hline \multirow[t]{2}{*}{$\begin{array}{l}\text { Academic institutions doing research } \\
\text { (e.g. universities) } \\
* \text { * must provide value }\end{array}$} & ○ & ○ & ○ & 0 & 0 & 0 \\
\hline & & & & & & reset \\
\hline \multirow[t]{2}{*}{$\begin{array}{l}\text { A national charity doing research (e.g. } \\
\text { MIND, Cancer Research UK, British } \\
\text { Heart Foundation) } \\
{ }^{*} \text { must provide value }\end{array}$} & ○ & 0 & ○ & O & $\bigcirc$ & 0 \\
\hline & & & & & & reset \\
\hline \multirow[t]{2}{*}{$\begin{array}{l}\text { A profit-making company doing } \\
\text { research into treatments (e.g. } \\
\text { pharmaceutical company, health } \\
\text { technology company) } \\
\text { * must provide value }\end{array}$} & O & ○ & 0 & O & ○ & 0 \\
\hline & & & & & & reset \\
\hline \multirow[t]{2}{*}{$\begin{array}{l}\text { A profit-making company doing other } \\
\text { research (e.g. insurance company, } \\
\text { broadband provider) } \\
\text { * must provide value }\end{array}$} & 0 & 0 & 0 & ○ & O & 0 \\
\hline & & & & & & reset \\
\hline \multirow[t]{4}{*}{$\begin{array}{l}\text { Publicly } \\
\text { * must provide value }\end{array}$} & $\bigcirc$ & ○ & ○ & 0 & $\bigcirc$ & \\
\hline & \multicolumn{2}{|c|}{$\ll$ Previous Page } & & & & \\
\hline & \multicolumn{2}{|c|}{ Next Page >> } & & & & \\
\hline & \multicolumn{2}{|c|}{ Save \& Return Later } & & & & \\
\hline
\end{tabular}


medRxiv preprint doi: https://doi.org/10.1101/2021.07.19.21260635; this version posted July 19, 2021. The copyright holder for this preprint (which was not certified by peer review) is the author/funder, who has granted medRxiv a license to display the preprint in perpetuity.

It is made available under a CC-BY 4.0 International license.

\section{NHS Data Consent Survey}

The final question in this section relates to sharing de-identified "free text" data for research.

Here is the table of de-identified health care data you saw earlier, but this time a column labelled

"Notes" has been added. This is known as "free text" data.

\begin{tabular}{|c|c|c|c|c|c|}
\hline $\begin{array}{l}\text { Research } \\
\text { ID }\end{array}$ & Age & Sex & Region & Diagnoses & Notes \\
\hline $5 \times 62 \mathrm{~V}$ & 69 & $M$ & Kent & $\begin{array}{l}\text { pneumonia } \\
\text { high blood pressure }\end{array}$ & $\begin{array}{l}1^{\text {st }} \text { April 2019. XXX has a fever and } \\
\text { cough. His chest sounds crackly. I think } \\
\text { he has pneumonia. Sent to hospital. }\end{array}$ \\
\hline 597PT & 24 & $F$ & Dundee & $\begin{array}{l}\text { depression } \\
\text { carpal tunnel } \\
\text { syndrome }\end{array}$ & $\begin{array}{l}2^{\text {nd }} \text { April 2019. XXX rates her mood as } \\
1 / 10 \text { on average, she is more tired, and } \\
\text { she is not looking forward to anything. } \\
\text { Her depression has worsened. She } \\
\text { wishes to restart citalopram. }\end{array}$ \\
\hline 8HG7S & 89 & $\mathbf{F}$ & Glamorganshire & $\begin{array}{l}\text { broken humerus } \\
\text { anxiety }\end{array}$ & $\begin{array}{l}3^{\text {rd }} \text { April 2019. XXX fell after skidding } \\
\text { on an oily patch while cycling and was } \\
\text { hit by a car. She has an obvious } \\
\text { fracture of her left upper arm. She } \\
\text { needs an X-ray. }\end{array}$ \\
\hline BA6A9 & 45 & $M$ & London & $\begin{array}{l}\text { schizophrenia } \\
\text { diabetes }\end{array}$ & $\begin{array}{l}4^{\text {th }} \text { April 2019. XXX still worries that } \\
\text { other people can hear his thoughts, } \\
\text { but this is getting less common. He is } \\
\text { attending cognitive-behavioural } \\
\text { therapy sessions. }\end{array}$ \\
\hline
\end{tabular}

Like the last example the data remains de-identified but gives the researchers more information. As there is more information there is a slightly increased risk of someone being identified from the data.

For example, in the table above, an "89-year-old cyclist skidding on oil and being hit by a car" may be reported in a local newspaper. Whilst the lady is not named in the data above, she would almost certainly be named in the newspaper and it may therefore be possible for researchers to work out who she is.

\begin{tabular}{|c|}
\hline \& Previous Page \\
\hline Next Page $>>$
\end{tabular}


medRxiv preprint doi: https://doi.org/10.1101/2021.07.19.21260635; this version posted July 19, 2021. The copyright holder for this preprint (which was not certified by peer review) is the author/funder, who has granted medRxiv a license to display the preprint in perpetuity.

It is made available under a CC-BY 4.0 International license.

\section{NHS Data Consent Survey}

Page 19 of 29

How likely would you be to share your FREE TEXT de-identified PHYSICAL health data with the following, without giving consent every time:

\begin{tabular}{|c|c|c|c|c|c|c|}
\hline & Very likely & Likely & Not sure & Unlikely & $\begin{array}{l}\text { Very } \\
\text { unlikely }\end{array}$ & $\begin{array}{l}\text { Prefer not } \\
\text { to say }\end{array}$ \\
\hline $\begin{array}{l}\text { Any part of the NHS doing research } \\
* \text { must provide value }\end{array}$ & 0 & 0 & 0 & 0 & ○ & reset \\
\hline $\begin{array}{l}\text { Academic institutions doing research } \\
\text { (e.g. universities) } \\
\text { * must provide value }\end{array}$ & ○ & 0 & ○ & ○ & - & 0 \\
\hline & & & & & & reset \\
\hline $\begin{array}{l}\text { A national charity doing research (e.g } \\
\text { MIND, Cancer Research UK, British } \\
\text { Heart Foundation) } \\
\text { * must provide value }\end{array}$ & ○ & ○ & ○ & ○ & - & 0 \\
\hline & & & & & & reset \\
\hline $\begin{array}{l}\text { A profit-making company doing } \\
\text { research into treatments (e.g. } \\
\text { pharmaceutical company, health } \\
\text { technology company) } \\
\text { * must provide value }\end{array}$ & ○ & ○ & 0 & O & - & 0 \\
\hline & & & & & & reset \\
\hline $\begin{array}{l}\text { A profit-making company doing other } \\
\text { research (e.g. insurance company, } \\
\text { broadband provider) } \\
\text { * must provide value }\end{array}$ & 0 & 0 & O & 0 & - & $\bigcirc$ \\
\hline & & & & & & reset \\
\hline $\begin{array}{l}\text { Publicly } \\
\text { * must provide value }\end{array}$ & $\bigcirc$ & ○ & ○ & 0 & - & \\
\hline & \multicolumn{2}{|c|}{$\ll$ Previous Page } & & & & \\
\hline & \multicolumn{2}{|c|}{ Next Page >> } & & & & \\
\hline & \multicolumn{2}{|c|}{ Save \& Return Later } & & & & \\
\hline
\end{tabular}


medRxiv preprint doi: https://doi.org/10.1101/2021.07.19.21260635; this version posted July 19, 2021. The copyright holder for this preprint (which was not certified by peer review) is the author/funder, who has granted medRxiv a license to display the preprint in perpetuity.

It is made available under a CC-BY 4.0 International license.

\section{NHS Data Consent Survey}

Page 20 of 29

How likely would you be to share your FREE TEXT de-identified MENTAL health data with the following, without giving consent each time:

\begin{tabular}{|c|c|c|c|c|c|c|}
\hline & Very likely & Likely & Not sure & Unlikely & $\begin{array}{l}\text { Very } \\
\text { unlikely }\end{array}$ & $\begin{array}{l}\text { Prefer not } \\
\text { to say }\end{array}$ \\
\hline $\begin{array}{l}\text { Any part of the NHS doing research } \\
\text { * must provide value }\end{array}$ & 0 & $\bigcirc$ & 0 & 0 & 0 & reset \\
\hline $\begin{array}{l}\text { Academic institutions doing research } \\
\text { (e.g. universities) } \\
\text { * must provide value }\end{array}$ & ○ & 0 & ○ & ○ & ○ & $\bigcirc$ \\
\hline $\begin{array}{l}\text { A national charity doing research (e.g } \\
\text { MIND, Cancer Research UK, British } \\
\text { Heart Foundation) } \\
\text { * must provide value }\end{array}$ & 0 & O & O & O & O & 0 \\
\hline $\begin{array}{l}\text { A profit-making company doing } \\
\text { research into treatments (e.g. } \\
\text { pharmaceutical company, health } \\
\text { technology company) } \\
\text { * must provide value }\end{array}$ & 0 & ○ & O & 0 & $\bigcirc$ & O \\
\hline $\begin{array}{l}\text { A profit-making company doing other } \\
\text { research (e.g. insurance company, } \\
\text { broadband provider) } \\
\text { * must provide value }\end{array}$ & O & 0 & 0 & 0 & O & $0^{\text {reset }}$ \\
\hline $\begin{array}{l}\text { Publicly } \\
\text { * must provide value }\end{array}$ & 0 & $\bigcirc$ & ○ & ○ & 0 & $0^{\text {reset }}$ \\
\hline & \multicolumn{2}{|c|}{$\ll$ Previous Page } & & & & \\
\hline & \multicolumn{2}{|c|}{ Next Page >> } & & & & \\
\hline & Save \& $\operatorname{Re}$ & rn Later & & & & \\
\hline
\end{tabular}


medRxiv preprint doi: https://doi.org/10.1101/2021.07.19.21260635; this version posted July 19, 2021. The copyright holder for this preprint (which was not certified by peer review) is the author/funder, who has granted medRxiv a license to display the preprint in perpetuity.

It is made available under a CC-BY 4.0 International license.

\section{NHS Data Consent Survey}

Page 21 of 29

On a slightly different topic...

Imagine that there was a single place where you could securely sign up to choose how your NHS identifiable health data is used. This would cover how your confidential patient information is managed across all UK NHS services, and how your NHS de-identified data could (or could not) be used for research.

It would be in the form of a standardised UK-wide CONSENT FORM that all NHS services could use.

How likely would you be to sign up if you were asked to sign:

Online (via a website)

Very likely Likely

Not sure Unlikely

Very

Prefer not

* must provide value

$\bigcirc$

likely

to say

By downloading an app

* must provide value

On paper forms available from

pharmacies, the Post Office, etc. (and

sent by post)

* must provide value

In person (e.g. when attending your

GP, at a hospital clinic, etc.)

* must provide value

$\ll$ Previous Page

Next Page $>$ 
medRxiv preprint doi: https://doi.org/10.1101/2021.07.19.21260635; this version posted July 19, 2021. The copyright holder for this preprint (which was not certified by peer review) is the author/funder, who has granted medRxiv a license to display the preprint in perpetuity.

It is made available under a CC-BY 4.0 International license.

\section{NHS Data Consent Survey}

Page 22 of 29

Would you be likely to sign up if your consent form were then stored and managed securely by the following institutions?

$\begin{aligned} & \text { Centrally by NHS England/NHS } \\ & \text { Scotland/NHS Wales/HSC Northern } \\ & \text { Ireland } \\ & \text { * must provide value }\end{aligned}$
$\begin{aligned} & \text { Vory likely } \\ & \text { Your local NHS Trust }\end{aligned}$
Youst provide value
* must provide value

$<$ Previous Page

Next Page >> 
medRxiv preprint doi: https://doi.org/10.1101/2021.07.19.21260635; this version posted July 19, 2021. The copyright holder for this preprint (which was not certified by peer review) is the author/funder, who has granted medRxiv a license to display the preprint in perpetuity.

It is made available under a CC-BY 4.0 International license.

\section{NHS Data Consent Survey}

If you wanted to change your preferences, how likely would you be to use the following methods?

Online (via a website)

* must provide value

\begin{tabular}{cccccc} 
Very likely & Likely & Not sure & Unlikely & $\begin{array}{c}\text { Very } \\
\text { unlikely }\end{array}$ & $\begin{array}{c}\text { Prefer not } \\
\text { to say }\end{array}$ \\
\hline & & & & &
\end{tabular}

By downloading an app

* must provide value

O

On paper forms available from

pharmacies, Post Office, etc. (and

sent by post)

* must provide value

In person (e.g. when attending your

GP, at a hospital clinic, etc.)

* must provide value

$\ll$ Previous Page

Next Page $>>$ 
medRxiv preprint doi: https://doi.org/10.1101/2021.07.19.21260635; this version posted July 19, 2021. The copyright holder for this preprint which was not certified by peer review) is the author/funder, who has granted medRxiv a license to display the preprint in perpetuity.

It is made available under a CC-BY 4.0 International license.

NHS Data Consent Survey

Assume that you were able to sign up and change your choices in a way you preferred, and that the consent form was stored securely in a place where you felt comfortable.

How likely would you be to use this system to choose how your NHS health data is managed?

Oery likely
Overall likelihood that you would sign

$\ll$ Previous Page

Next Page >>

Save \& Return Later 
medRxiv preprint doi: https://doi.org/10.1101/2021.07.19.21260635; this version posted July 19, 2021. The copyright holder for this preprint

(which was not certified by peer review) is the author/funder, who has granted medRxiv a license to display the preprint in perpetuity.

It is made available under a CC-BY 4.0 International license.

NHS Data Consent Survey

Page 25 of 29

The last part of the survey (before we ask a few questions to ensure we have reached a broad section of the UK) examines what a consent form to share our health data could look like.

By completing one consent form it would then be possible for all UK NHS professionals to access their patient's identifiable health data for their clinical care, saving time for both patients and health care professionals.

Please take a look at the consent form below:

National NHS/HSC data sharing consent form

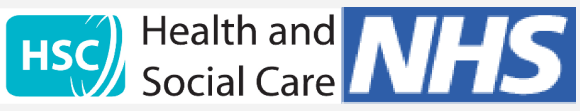

Full name

Date of birth

NHS number

Address

E-mail address

I confirm I have read the information sheet 'Sharing My Health Data' version XXX dated XXX. I have had the opportunity to consider the information and ask questions. I understand that my participation is voluntary, and that I am free to change or withdraw my consent at any time, without giving a reason and without my medical care or rights being affected.

\title{
1. Providing health care to you
}

Confidential patient information is information that can identify you and that says something about your health care or treatment. Information about you might be held by several NHS organizations (such as GP surgeries and hospitals). May they share your information with each other when providing health care to you?

\begin{abstract}
I agree that all NHS care providers and professionals may share my confidential patient information with each other for the purpose of my treatment and care.
\end{abstract}

\section{Using your de-identified data to help others}

The NHS promises to anonymise the information collected during the course of your treatment and use it to support research and improve care for others. Research is conducted by the NHS and by NHS-approved researchers in organizations such as universities. Strict security controls apply to the use of NHS data, even after information that might identify you (such as names and addresses) has been removed. All research involving NHS data must be approved by the NHS.

Saying no doesn't prevent all uses of your confidential information for research. To do that, use the national data opt-out at https://www.nhs.uk/your-nhs-data-matters.

I agree that all NHS care providers may share my confidential patient information with each other and de-identify it for the purpose of research.

\section{Taking part in research}

Some research involves direct participation. This ranges from questionnaires to trials of new treatments. The NHS promises to inform you of research studies in which you may be eligible to participate. There is never a commitment to take part.

I agree that NHS-approved researchers may learn my identity and contact me Yes [] No [ ] directly about research studies for which I may be eligible.

Signature:

Date: 
medRxiv preprint doi: https://doi.org/10.1101/2021.07.19.21260635; this version posted July 19, 2021. The copyright holder for this preprint (which was not certified by peer review) is the author/funder, who has granted medRxiv a license to display the preprint in perpetuity.

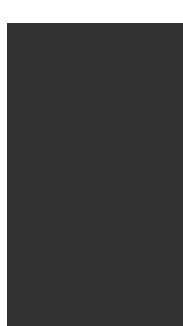

$\ll$ Previous Page

Next Page >>

Save \& Return Later 
medRxiv preprint doi: https://doi.org/10.1101/2021.07.19.21260635; this version posted July 19,2021 . The copyright holder for this preprint (which was not certified by peer review) is the author/funder, who has granted medRxiv a license to display the preprint in perpetuity.

It is made available under a CC-BY 4.0 International license.

NHS Data Consent Survey

Having looked at the consent form, please agree or disagree with the following statements.

(If you would like to take another look at the consent form at any time while answering this question, you can use the 'previous' button at the bottom of this page to look back. This will not affect answers already given.)

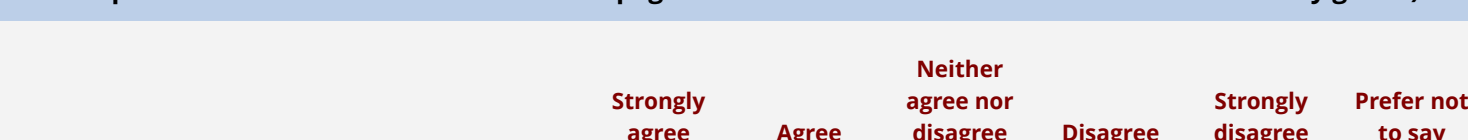

The consent form is easy to read.

agree

Agree

disagree

disagree

to say

* must provide value

The consent form is clear and easy to

understand.

* must provide value

The statements (in blue) help me to understand what I am consenting to.

* must provide value

The consent form is clear that my identifiable health data would only be used by appropriate NHS health care professionals.

* must provide value

I understand the term 'NHS-approved researchers' and which individuals this may refer to.

* must provide value

The consent form makes clear that it would be used for my preferences about sharing my IDENTIFIABLE health data within the NHS for my CLINICAL CARE.

* must provide value

The consent form makes clear that it would also be used for my preferences about sharing my DEIDENTIFIED health data for RESEARCH purposes.

* must provide value

I would like the consent form to give specific options about how

researchers can contact me (e.g. by post only, e-mail)

post only, e-mail).

I would like to see a statement added about the security of data sharing.

* must provide value

I would like to see a statement added about where my consent preferences will be stored.

must provide value

Before seeing this consent form I was aware of the NHS National Data Opt-

Out.

* must provide value

The consent form reassures me that my identifiable health data is safe in the NHS.

* must provide value

If this consent form were put in front of me today, I would sign it

* must provide value 
medRxiv preprint doi: https://doi.org/10.1101/2021.07.19.21260635; this version posted July 19, 2021. The copyright holder for this preprint (which was not certified by peer review) is the author/funder, who has granted medRxiv a license to display the preprint in perpetuity.

It is made available under a CC-BY 4.0 International license.

If you would like to make any comments about the consent form, please do so here:

Next Page $\gg$ 
medRxiv preprint doi: https://doi.org/10.1101/2021.07.19.21260635; this version posted July 19, 2021. The copyright holder for this preprint (which was not certified by peer review) is the author/funder, who has granted medRxiv a license to display the preprint in perpetuity.

It is made available under a CC-BY 4.0 International license.

\section{NHS Data Consent Survey}

There are currently many individual websites where people can sign up to take part in research. Examples include charity websites, the national "Join Dementia Research" register, and the National Institute for Health Research (NIHR) "be part of research" campaign.

An alternative might be a national sign-up portal, on a web site, where people could register their preferences about taking part in all NHS research.

\section{Choose the statement you agree with most:}

* must provide value

Everything is fine as it is; leave it to individuals to sign up with the various organisations.

Have two national NHS research websites, one where people can sign up for mental health research, and a second website where people can sign up for physical health research.

Have a national NHS research website where people can sign up for all conditions.

Not sure.

$\ll$ Previous Page

Next Page $>$ 
medRxiv preprint doi: https://doi.org/10.1101/2021.07.19.21260635; this version posted July 19, 2021. The copyright holder for this preprint (which was not certified by peer review) is the author/funder, who has granted medRxiv a license to display the preprint in perpetuity. It is made available under a CC-BY 4.0 International license .

\section{NHS Data Consent Survey}

Finally, it can be very valuable for research to link health (NHS) data to other data sources.

For example, causes of death (from death certificates) are held by the UK Office of National Statistics (ONS), rather than the NHS -- so to find out more about the reasons people die, NHS and ONS data must be linked.

Usually, this is done as follows:

a) Research teams seek special permission for the process.

b) The relevant information from each organization, plus a small amount of identifiable information, is given to a "trusted third party" (e.g. an NHS Trust, the Office of National Statistics).

c) The trusted third party links the information, then removes any details that can identify anyone.

d) Researchers are then given access to the de-identified information only, under special controls.

We are interested to hear whether you would be happy for your health data to be linked, in this way, to:

Educational data (e.g. to study impact

Yes

Not sure

No

Prefer not to say

of illness on education)

* must provide value

Police/Criminal Justice data (e.g. to study health in the victims of crime) * must provide value

Transport/DVLA data (e.g. to study health and pollution)

* must provide value

Housing data (e.g. impact of social housing on health)

* must provide value

Immigration data (e.g. health in

immigrants)

* must provide value

Social security/Work and Pensions (e.g. health and financial insecurity) * must provide value

Data held about you for research by universities (e.g. if you have

volunteered for research studies) * must provide value

Data held about you by private companies

* must provide value 
medRxiv preprint doi: https://doi.org/10.1101/2021.07.19.21260635; this version posted July 19,2021 . The copyright holder for this preprint (which was not certified by peer review) is the author/funder, who has granted medRxiv a license to display the preprint in perpetuity.

It is made available under a CC-BY 4.0 International license.

NHS Data Consent Survey

And finally, to ensure we have surveyed a wide range of the population (please note, all questions have a "prefer not to say" option and have been written to apply to all of the home nations):

\author{
* must provide value \\ Prefer not to say \\ Female \\ Male \\ Prefer to self describe
}

Do you consider yourself to be:

\title{
May we know which age range you fit in?
}
* must provide value
Prefer not to say
Under 12
$12-15$
16-17
$18-24$
25-34
35-44
45-54
55-64
65-74
$75-84$
$85+$

\section{What do you consider your ethnicity to be?}

* must provide value

Prefer not to say

White

Irish Traveller

Mixed/Multiple ethnic groups

Asian or Asian British

Indian

Pakistani

Bangladeshi

Chinese

Black/African/Caribbean/Black British

Arab

Other or prefer to self describe 
medRxiv preprint doi: https://doi.org/10.1101/2021.07.19.21260635; this version posted July 19,2021 . The copyright holder for this preprint (which was not certified by peer review) is the author/funder, who has granted medRxiv a license to display the preprint in perpetuity.

It is made available under a CC-BY 4.0 International license.

\section{What is the highest qualification you have achieved?}

* must provide value

Prefer not to say

No formal qualifications

Secondary school level qualifications e.g. CSE, GCSE, O-Levels, Nationals, or equivalent

A-Levels, Highers, or equivalent

Vocational qualification or equivalent

Undergraduate degree or equivalent

Postgraduate or professional qualification or equivalent

\section{Do you consider yourself to be}
* must provide value
Prefer not to say
Heterosexual (straight)
Homosexual (gay or lesbian)
Bisexual
Other or prefer to self describe

What is your religion, if any?

* must provide value
Prefer not to say
No religion
Christian
Muslim
Hindu
Sikh
Jewish
Buddhist
Other or prefer to self describe

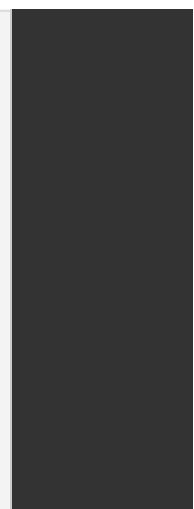

Thinking about your current (or last) main job or occupation. Do (did) you work as an employee or are (were) you self-employed?

* must provide value

Prefer not to say

Never worked

Employee

Self-employed with employees

Self-employed/freelance without employees

\section{And where in the UK do you currently live?}

* must provide value

Prefer not to say

England

Northern Ireland

Scotland

Wales

Channel Islands

Isle of Man

None of these

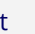

\section{re}


medRxiv preprint doi: https://doi.org/10.1101/2021.07.19.21260635; this version posted July 19, 2021. The copyright holder for this preprint (which was not certified by peer review) is the author/funder, who has granted medRxiv a license to display the preprint in perpetuity.

It is made available under a CC-BY 4.0 International license.

We would like to know your postcode so that we can analyse our results by "geography", such as urban versus rural areas. You do not have to give this. However if you do, we will never disclose it or identify you from it.

* must provide value

I prefer not to give my postcode

I am happy to give my postcode

Before you submit your answers there is the option to leave an e-mail address should you wish to have the final report of the survey results personally e-mailed to you.

Please note: all e-mail addresses will be removed from the survey answers so that you cannot be identified, and will be held securely on password-protected computers at the University of Cambridge until the results are available, as described in the information sheet at the start of the survey.

If you wish to leave an e-mail address, please do so in the box below (and then submit your answers). Otherwise, please submit your answers now.

\section{Optional}

$\ll$ Previous Page

Submit 
medRxiv preprint doi: https://doi.org/10.1101/2021.07.19.21260635; this version posted July 19,2021 . The copyright holder for this preprint (which was not certified by peer review) is the author/funder, who has granted medRxiv a license to display the preprint in perpetuity.

It is made available under a CC-BY 4.0 International license.

NHS Data Consent Survey

Page 29 of 29

And finally, to ensure we have surveyed a wide range of the population (please note, all questions have a "prefer not to say" option and have been written to apply to all of the home nations):

Do you consider yourself to be:

* must provide value

Prefer not to say

Female

Male

- Prefer to self describe

Prefer to self describe (please specify)

May we know which age range you fit in?

* must provide value

Prefer not to say

- Under 12

$12-15$

16-17

$18-24$

25-34

35-44

45-54

55-64

65-74

$75-84$

$85+$

Please tick which of the two options applies:

* must provide value

I completed the survey by myself

I had help to complete the survey

\section{What do you consider your ethnicity to be?}

* must provide value

Prefer not to say

White

Irish Traveller

Mixed/Multiple ethnic groups

Asian or Asian British

Indian

Pakistani

Bangladeshi

Chinese

Black/African/Caribbean/Black British

Arab

- Other or prefer to self describe 
medRxiv preprint doi: https://doi.org/10.1101/2021.07.19.21260635; this version posted July 19,2021 . The copyright holder for this preprint (which was not certified by peer review) is the author/funder, who has granted medRxiv a license to display the preprint in perpetuity.

It is made available under a CC-BY 4.0 International license .

Other or prefer to self describe (please specify)

What is the highest qualification you have achieved?

* must provide value

Prefer not to say

No formal qualifications

Secondary school level qualifications e.g. CSE, GCSE, O-Levels, Nationals, or equivalent

A-Levels, Highers, or equivalent

Vocational qualification or equivalent

Undergraduate degree or equivalent

Postgraduate or professional qualification or equivalent

reset

\section{Do you consider yourself to be}

* must provide value

Prefer not to say

Heterosexual (straight)

Homosexual (gay or lesbian)

Bisexual

- Other or prefer to self describe

Other or prefer to self describe (Please specify)

What is your religion, if any?

* must provide value

Prefer not to say

No religion

Christian

Muslim

Hindu

Sikh

Jewish

Buddhist

- Other or prefer to self describe

Other or prefer to self describe (please specify)

Thinking about your current (or last) main job or occupation. Do (did) you work as an employee or are (were) you self-employed?

* must provide value

Prefer not to say

Never worked

- Employee

Self-employed with employees

Self-employed/freelance without employees 
medRxiv preprint doi: https://doi.org/10.1101/2021.07.19.21260635; this version posted July 19,2021 . The copyright holder for this preprint (which was not certified by peer review) is the author/funder, who has granted medRxiv a license to display the preprint in perpetuity.

It is made available under a CC-BY 4.0 International license.

\section{How many people work (worked) for your employer at the place where you work (worked)?}

Prefer not to say

1-24

- 25 or more

\section{Do (did) you supervise any other employees on a day to day basis?}

Prefer not to say

- Yes

No

\section{And which best describes the work you do (did)?}

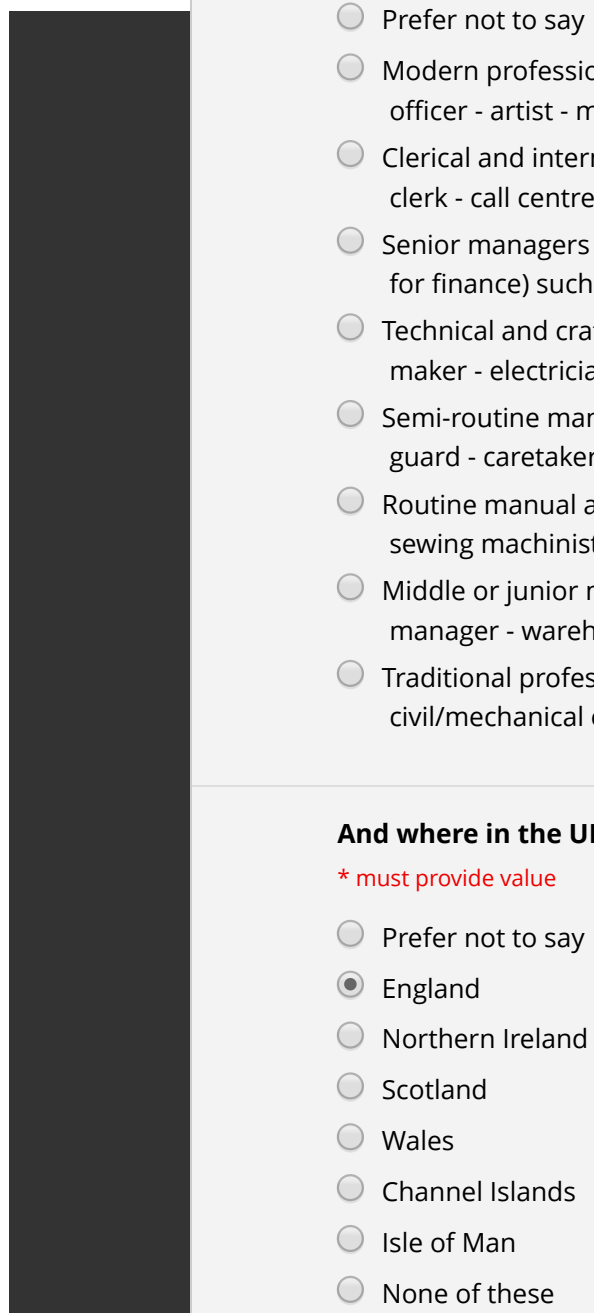

\section{And where in the UK do you currently live?}

must provide value 
medRxiv preprint doi: https://doi.org/10.1101/2021.07.19.21260635; this version posted July 19, 2021. The copyright holder for this preprint (which was not certified by peer review) is the author/funder, who has granted medRxiv a license to display the preprint in perpetuity.

It is made available under a CC-BY 4.0 International license .

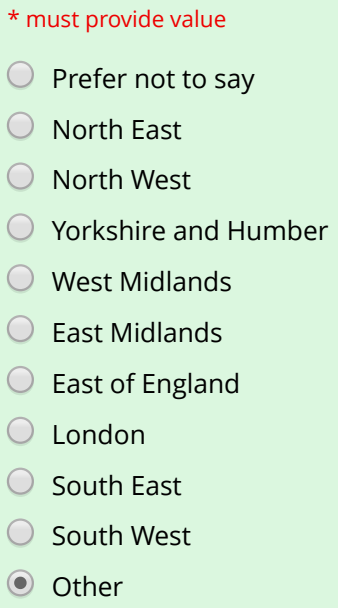

Other (please specify)

We would like to know your postcode so that we can analyse our results by "geography", such as urban versus rural areas. You do not have to give this. However if you do, we will never disclose it or identify you from it.

* must provide value

I prefer not to give my postcode

- I am happy to give my postcode

\section{Postcode}

Before you submit your answers there is the option to leave an e-mail address should you wish to have the final report of the survey results personally e-mailed to you.

Please note: all e-mail addresses will be removed from the survey answers so that you cannot be identified, and will be held securely on password-protected computers at the University of Cambridge until the results are available, as described in the information sheet at the start of the survey.

If you wish to leave an e-mail address, please do so in the box below (and then submit your answers). Otherwise, please submit your answers now.

Optional

\begin{tabular}{|c|}
\hline$\ll$ Previous Page \\
\hline Submit \\
\hline
\end{tabular}


medRxiv preprint doi: https://doi.org/10.1101/2021.07.19.21260635; this version posted July 19, 2021. The copyright holder for this preprint (which was not certified by peer review) is the author/funder, who has granted medRxiv a license to display the preprint in perpetuity.

It is made available under a CC-BY 4.0 International license .

STROBE Statement —Checklist of items that should be included in reports of cross-sectional studies

Jones et al.: Public opinion on sharing data from UK health services for clinical and research purposes without explicit consent, 2021

$$
\begin{gathered}
\text { Item } \\
\text { No }
\end{gathered}
$$

Section $(\S$, main text section; $S$, supplementary;

$F$, figure; $T$, table)

\begin{tabular}{lll|l}
\hline Title and abstract & $\begin{array}{l}\text { (a) Indicate the study's design with a commonly used term in } \\
\text { the title or the abstract }\end{array}$ & $\S 1$ \\
\cline { 2 - 4 } & $\begin{array}{l}\text { (b) Provide in the abstract an informative and balanced summary } \\
\text { of what was done and what was found }\end{array}$ & \\
\hline
\end{tabular}

\section{Introduction}

\begin{tabular}{lll|l}
\hline Background/rationale & 2 & $\begin{array}{l}\text { Explain the scientific background and rationale for the } \\
\text { investigation being reported }\end{array}$ & $\S 2$ \\
\hline Objectives & 3 & State specific objectives, including any prespecified hypotheses & $\S 2$ \\
\hline
\end{tabular}

\begin{tabular}{|c|c|c|c|}
\hline Study design & 4 & Present key elements of study design early in the paper & $\S 2, \S 3$ \\
\hline Setting & 5 & $\begin{array}{l}\text { Describe the setting, locations, and relevant dates, including } \\
\text { periods of recruitment, exposure, follow-up, and data collection }\end{array}$ & $\S 3.3-3.5$ \\
\hline Participants & 6 & $\begin{array}{l}\text { (a) Give the eligibility criteria, and the sources and methods of } \\
\text { selection of participants }\end{array}$ & $\S 3.3$ \\
\hline Variables & 7 & $\begin{array}{l}\text { Clearly define all outcomes, exposures, predictors, potential } \\
\text { confounders, and effect modifiers. Give diagnostic criteria, if } \\
\text { applicable }\end{array}$ & $\S 3.5-3.9, \mathrm{~S} 1.2$ \\
\hline $\begin{array}{l}\text { Data sources/ } \\
\text { measurement }\end{array}$ & $8^{*}$ & $\begin{array}{l}\text { For each variable of interest, give sources of data and details of } \\
\text { methods of assessment (measurement). Describe comparability } \\
\text { of assessment methods if there is more than one group }\end{array}$ & $\S 3.5$ \\
\hline Bias & 9 & Describe any efforts to address potential sources of bias & $\S 3.9, \mathrm{~S} 1.3$ \\
\hline Study size & 10 & Explain how the study size was arrived at & $\S 3.3$ \\
\hline Quantitative variables & 11 & $\begin{array}{l}\text { Explain how quantitative variables were handled in the analyses. } \\
\text { If applicable, describe which groupings were chosen and why }\end{array}$ & $\S 3.9, \mathrm{~S} 1.2-\mathrm{S} 1.4$ \\
\hline \multirow[t]{2}{*}{ Statistical methods } & 12 & $\begin{array}{l}\text { (a) Describe all statistical methods, including those used to } \\
\text { control for confounding }\end{array}$ & $\S 3.9, \mathrm{~S} 1.3-\mathrm{S} 1.4$ \\
\hline & & (b) Describe any methods used to examine subgroups and & $\S 3.9, \mathrm{~S} 1.4$ \\
\hline
\end{tabular}

\section{Methods}


medRxiv preprint doi: https://doi.org/10.1101/2021.07.19.21260635; this version posted July 19, 2021. The copyright holder for this preprint (which was not certified by peer review) is the author/funder, who has granted medRxiv a license to display the preprint in perpetuity.

It is made available under a CC-BY 4.0 International license .

\begin{tabular}{ll|l}
\hline interactions & \\
\cline { 2 - 3 }$(c)$ Explain how missing data were addressed & $\S 3.9$ \\
\cline { 2 - 3 }$($ d $)$ If applicable, describe analytical methods taking account of & $\S 3.8-3.9, \mathrm{~S} 1.3-$ \\
sampling strategy & S1.4 \\
\hline$(\underline{e})$ Describe any sensitivity analyses & S1.3, ST1 \\
\hline
\end{tabular}

\section{Results}

\begin{tabular}{|c|c|c|c|}
\hline \multirow[t]{3}{*}{ Participants } & $13^{*}$ & $\begin{array}{l}\text { (a) Report numbers of individuals at each stage of study-eg } \\
\text { numbers potentially eligible, examined for eligibility, confirmed } \\
\text { eligible, included in the study, completing follow-up, and } \\
\text { analysed }\end{array}$ & $\S 4.1, \mathrm{~S} 2.5, \mathrm{SF} 1$ \\
\hline & & (b) Give reasons for non-participation at each stage & SF1 \\
\hline & & (c) Consider use of a flow diagram & SF1 \\
\hline \multirow[t]{2}{*}{ Descriptive data } & $14^{*}$ & $\begin{array}{l}\text { (a) Give characteristics of study participants (eg demographic, } \\
\text { clinical, social) and information on exposures and potential } \\
\text { confounders }\end{array}$ & $\begin{array}{l}\S 4.1, \mathrm{SF} 2, \mathrm{SF} 3, \\
\text { ST1 }\end{array}$ \\
\hline & & $\begin{array}{l}\text { (b) Indicate number of participants with missing data for each } \\
\text { variable of interest }\end{array}$ & $\begin{array}{l}\text { F2-F4, F6-F7, } \\
\text { SF1-SF7 }\end{array}$ \\
\hline Outcome data & $15^{*}$ & Report numbers of outcome events or summary measures & N/A \\
\hline \multirow[t]{3}{*}{ Main results } & 16 & $\begin{array}{l}\text { (a) Give unadjusted estimates and, if applicable, confounder- } \\
\text { adjusted estimates and their precision (eg, } 95 \% \text { confidence } \\
\text { interval). Make clear which confounders were adjusted for and } \\
\text { why they were included }\end{array}$ & F2-F7, SF4-SF7 \\
\hline & & $\begin{array}{l}\text { (b) Report category boundaries when continuous variables were } \\
\text { categorized }\end{array}$ & $\mathrm{S} 1.2$ \\
\hline & & $\begin{array}{l}\text { (c) If relevant, consider translating estimates of relative risk into } \\
\text { absolute risk for a meaningful time period }\end{array}$ & $\mathrm{N} / \mathrm{A}$ \\
\hline Other analyses & 17 & $\begin{array}{l}\text { Report other analyses done - eg analyses of subgroups and } \\
\text { interactions, and sensitivity analyses }\end{array}$ & $\begin{array}{l}\S 3.9, \S 4.3-4.6, \\
\mathrm{~S} 1.4, \mathrm{~S} 2.2-\mathrm{S} 2.10 \\
\mathrm{ST} 1, \mathrm{SF} 4-\mathrm{SF} 7\end{array}$ \\
\hline
\end{tabular}

\section{Discussion}

\begin{tabular}{lcl|l}
\hline Key results & 18 & Summarise key results with reference to study objectives & $\S 5.1$ \\
\hline Limitations & 19 & $\begin{array}{l}\text { Discuss limitations of the study, taking into account sources of } \\
\text { potential bias or imprecision. Discuss both direction and } \\
\text { magnitude of any potential bias }\end{array}$ & $\S 5.2$ \\
\hline Interpretation & 20 & Give a cautious overall interpretation of results considering & $\S 5.3-5.6$ \\
\hline
\end{tabular}


medRxiv preprint doi: https://doi.org/10.1101/2021.07.19.21260635; this version posted July 19,2021 . The copyright holder for this preprint (which was not certified by peer review) is the author/funder, who has granted medRxiv a license to display the preprint in perpetuity.

It is made available under a CC-BY 4.0 International license .

\begin{tabular}{ll|l|l}
\hline & $\begin{array}{l}\text { objectives, limitations, multiplicity of analyses, results from } \\
\text { similar studies, and other relevant evidence }\end{array}$ & \\
\hline Generalisability & 21 & $\begin{array}{l}\text { Discuss the generalisability (external validity) of the study } \\
\text { results }\end{array}$ & $\S 5.2$ \\
\hline Other information & 22 & $\begin{array}{l}\text { Give the source of funding and the role of the funders for the } \\
\text { present study and, if applicable, for the original study on which } \\
\text { the present article is based }\end{array}$ & $\S 8$ \\
\hline Funding & &
\end{tabular}

*Give information separately for exposed and unexposed groups.

Note: An Explanation and Elaboration article discusses each checklist item and gives methodological background and published examples of transparent reporting. The STROBE checklist is best used in conjunction with this article (freely available on the Web sites of PLoS Medicine at http://www.plosmedicine.org/, Annals of Internal Medicine at http://www.annals.org/, and Epidemiology at http://www.epidem.com/). Information on the STROBE Initiative is available at www.strobe-statement.org. 